\title{
TEKNOLOGI DAN PERILAKU SOSIAL PELAJAR (STUDI TENTANG DAMPAK PENGGUNAAN SMARTPHONE DI SMA NEGERI 3 MAKASSAR)
}

TECHNOLOGY AND SOCIAL BEHAVIOR OF STUDENTS ( STUDY ON THE UTILIZATION OF SMARTPHONE ON STUDENTS AT SMAN 3 MAKASSAR)

NUR INAYATI SAIFUL

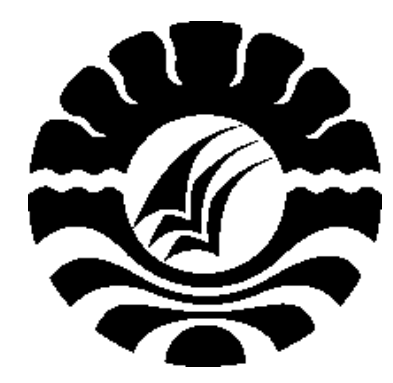

PROGRAM PASCASARJANA UNIVERSITAS NEGERI MAKASSAR 2016 


\section{LEMBAR PENGESAHAN}

Judul

NIM

Program Studi
: Teknologi dan Perilaku Sosial Pelajar

(Studi Tentang Dampak Penggunaan Smartphone Terhadap Perliku Sosial Pelajar SMA Negeri 3 Makassar)

: Nur Inayati Saiful

: 14B02017

: Pendidikan Sosiologi

\section{Menyetujui}

Komisi penasehat,

Prof. H. Hamdan Juhannis, M.A, Ph.D. Dr. Firdaus W Suhaeb, M.Si.

Mengetahui:

Ketua

Program Studi IPS

Pendidikan Sosiologi
Direktur

Program Pascasarjana

Universitas Negeri Makassar
Prof. Dr. Darman Manda, M.Hum. NIP: 196501031990031001
Prof. Dr. Jasruddin, M.Si.

NIP:1964122219911031002 


\begin{abstract}
ABSTRAK
NUR INAYATI SAIFUL. Teknologi dan Perilaku Sosial Pelajar (Studi Tentang Dampak Penggunaan Smartphone di SMA Negeri 3 Makassar ) (Dibimbing oleh Hamdan Juhannis dan Firdaus).

Tujuan penelitian ini adalah (1) Untuk mengetahui faktor-faktor yang mendorong pelajar SMA Negeri 3 Makassar menggunakan smartphone (2) Untuk mengetahui gambaran perubahan perilaku sosial pelajar yang menggunakan smartphone di SMA Negeri 3 Makassar (3) Untuk mengetahui dampak penggunaan smartphone pada perilaku sosial pelajar di SMA Negeri 3 Makassar.

Penelitian ini merupakan penelitian kualitatif dengan menggunakan teknik observasi, wawancara, dan dokumentasi. Analisis data dilakukan secara deskriptif melalui tahap reduksi data, penyajian dan pengelolahan data, serta penarikan kesimpulan.

Hasil penelitian menunjukkan, bahwa Penggunaan smartphone pada pelajar (1) dilatar belakangi oleh faktor pribadi, yakni adanya keinginan diri sendiri, faktor psikologi, yakni adanya dorongan, motivasi, serta persepsi dalam menggunakan smartphone dan faktor sosial, yakni adanya status sosial keluarga serta dorongan dari teman. (2) telah tergambarkan bahwa terjadi perubahan perilaku sosial pelajar sebelum dan sesudah menggunakan smartphone seperti adanya kepercayan diri, mandiri, diterima atau ditolak oleh orang lain, mudah bergaul, perilaku pamer dan daya saing yang tinggi. (3) dengan penggunaan smartphone di dalam lingkungan sekolah memberikan dampak positif yakni memudahkan mendapatkan sumber belajar, memudahkan berkomunikasi, mampu meningkatkan popularitas, memberikan sebuah kenikmatan tersendiri terhadap dunia hiburan yang menjanjikan, dan negatifnya berpengaruh kesehatan atau radiasi cahaya, kesenjangan berinteraksi, hubungan palsu, serta terkhusus mengalami kecanduan.
\end{abstract}

Kata kunci: Teknologi, Perilaku Sosial, dan Smartphone. 


\section{PRAKATA}

Penulis panjatkan puji syukur kehadirat Allah SWT, atas rahmat dan hidayah-Nya sehingga penelitian dan penyusunan tesis dengan judul "teknologi dan perilaku sosial pelajar (studi tentang dampak penggunaan smartphone di SMA Negeri 3 Makassar).

Proses penyelesaian tesis ini, merupakan suatu perjuangan yang panjang bagi penulis. Selama proses penelitian dan penyusunan tesis ini, tidak sedikit kendala yang dihadapi. Namun demikian, berkat keseriusan pembimbing mengarahkan dan membimbing penulis sehingga tesis ini dapat diselesaikan dengan baik. Oleh karena itu, penulis patut menyampaikan penghargaan dan ucapan terima kasih setinggi-tingginya kepada Prof. $\mathrm{H}$. Hamdan Juhannis, M.A, Ph.D dan Dr. Firdaus W Suhaeb, M.Si selaku pembimbing. Ucapan terima kasih juga disampaikan kepada tim penguji, yaitu Dr. Hj. Syamsidah, M.Pd. dan Prof.Dr.H.Darman Manda.M.Hum. Yang banyak memberikan masukan yang sangat berarti dalam penyusunan laporan penelitian ini. Ucapan terima kasih tak lupa pula disampaikan kepada direktur program pasca sarjana universitas negeri Makassar, asisten direktur I, asisten direktur II dan ketua program studi ilmu pengetahuan sosial, yang telah memberikan kemudahan kepada penulisan, baik pada saat mengikuti perkuliahan, maupun pada saat pelaksanaan penelitian dan penyusunan laporan. Mudah-mudahan bantuan dan bimbingan yang diberikan mendapat pahala dari allah swt.

Terima kasih, penulis ucapkan kepada, Parman, Sahrul, Nurliah, St Hartina Ruslim, Sumitro, Sopian Tamrin, Syahban, Suharti Novial, Nur Vidia, Marni dan rekan-rekan lain yang 
tidak dapat disebutkan satu persatu, yang telah memberikan dorongan moril dalam perkuliahan, dan penyusunan tesis ini. Ucapan terima kasih juga penulis sampaikan kepada Sekolah SMA Negeri 3 Makassar. Telah menerima untuk melakukan penelitian, serta para pelajar sebagai informan penelitian.

Terwujudnya tesis ini juga atas doa, dorongan, dan restu kelurga. Oleh karena itu, penulis menghaturkan terima kasih kepada kedua orang tua saya ibunda Salbiah, S.Pd. dan ayahanda Saifullah, S.Pd yang selalu memberikan motivasi dan dukungan dalam pendidikan sampai selesainya penulisan tesis ini.

Akhirnya, penulis berharap semoga segala bantuan yang telah diberikan oleh berbagai pihak dapat bernilai ibadah dan mendapatkan pahala dari Allah Swt.

Makassar, Mei 2016

Nur Inayati Saiful 


\section{DAFTAR ISI}

HALAMAN SAMPUL

HALAMAN PERSETUJUAN TESIS

PRAKATA

PERNYATAAN KEORISINILAN TESIS

ABSTRAK

ABSTRACT

DAFTAR ISI

DAFTAR TABEL

DAFTAR GAMBAR

DAFTAR LAMPIRAN
Halaman

ii

iii

vi

vii

viii

ix

$x i$

xii

xiii

BAB I PENDAHULUAN

$\begin{array}{ll}\text { A. Latar Belakang } & 1\end{array}$

$\begin{array}{ll}\text { B. Rumusan Masalah } & 6\end{array}$

$\begin{array}{ll}\text { C. Tujuan Penelitian } & 6\end{array}$

$\begin{array}{ll}\text { D. Manfaat Penelitian } & 7\end{array}$

BAB II TINJAUAN PUSTAKA 
$\begin{array}{ll}\text { A. Teknologi } & 8\end{array}$

B. Penggunaan Smarphone Pada Pelajar 11

C. Perilaku Sosial 23

$\begin{array}{ll}\text { D. Landasan Teori } & 26\end{array}$

E. Penelitian Relevan 42

F. Kerangka Konsep 44

BAB III METODE PENELITIAN

A. Jenis dan Lokasi Penelitian $\quad 47$

B. Informan dan Sumber Data Penelitian 48

C. Fokus Penelitian 49

D. Instrumen Penelitian $\quad 50$

E. Teknik Pengumpulan Data $\quad 50$

F. Teknik Analisis Data 53

G. Teknik Keabsahan Data $\quad 55$

BAB V HASIL PENELITIAN DAN PEMBAHASAN

A. Gambaran Lokasi dan Subjek Penelitian $\quad 57$

B. Deskripsi Hasil Penelitian $\quad 63$

$\begin{array}{ll}\text { C. Pembahasan } & 77\end{array}$

BAB VI KESIMPULAN DAN SARAN

$\begin{array}{ll}\text { A. Kesimpulan } & 93\end{array}$

$\begin{array}{ll}\text { B. Saran } & 94\end{array}$

$\begin{array}{lr}\text { DAFTAR PUSTAKA } & 95\end{array}$

$\begin{array}{lr}\text { LAMPIRAN } & 98\end{array}$ 


\section{DAFTAR TABEL}

Nomor

4.1 Jumlah Pelajar Keseluruhan

4.2 Kelompok Umur Informan

4.3 Tingkat Kelas Informan

4.4 Jenis Kelamin Informan
Halaman

58

61

62

63 
DAFTAR GAMBAR

Nomor

2.1 Kerangka Konsep
Halaman

46 


\section{DAFTAR LAMPIRAN}

Nomor

1. Instrumen Penelitian

2. Format Panduan Wawancara

3. Pertanyaan

4. Deskripsi Informan dan Hasil Wawancara

5. Daftar Informan

6. Perbedaan Handphone dan Samarphone

7. Jadwal Kegiatan Penelitian

8. Jenis Samarphone yang Digunakan

9. Surat-Surat

10. Dokumentasi

11. Peta SMA Negeri 3 Makassar

12. Riwayat Hidup
Halaman

99

100

101

102

109

110

111

112

113

119

122

123 


\section{BAB I}

\section{PENDAHULUAN}

\section{A. Latar Belakang}

Peradaban hidup manusia secara berkesinambungan mengalami perubahan dan terus berkembang dari waktu ke waktu hingga mencapai titik puncaknya melalui peneman-penemuan baru. Terutama dalam bidang ilmu pengetahuan dan teknologi. Ilmu pengetahuan dan teknologi yang digunakan tentu saja disesuaiakan dengan tingkat peradaban kehidupan manusia, baik tradisional maupun modern.

Teknologi merupakan salah satu faktor dalam mempengaruhi perubahan sosial. Teknologi hampir selalu menjadi ciri modernitas, seorang individu seolah belum layak dikatakan sebagai manusia modern jika belum bersentuhan dengan teknologi. Salah satu ciri masyarakat tradisional adalah masih menerapkan dan menggunakan teknologi terbatas, menggunakan tenaga manusia untuk ukuran masyarakat modern. Sedangkan masyarakat modern adalah masyarakat yang dalam semua aspek kehidupannya ditandai dengan menggunakan berbagai alat, media maupun prasarana yang memberikan efektivitas dan efesiensi waktu, tenaga, pikiran, dan modal.

Seiring perkembangan teknologi informasi yang berkembang pesat di era globalisasi, smartphone sebagai alat komunikasi yang sangat diminati dan paling banyak digunakan oleh masyarakat, mulai dari masyarakat kota sampai ke pelosok 
Desa. Baik dari kalangan dewasa, anak kecil, pada kalangan pebisnis, para mahasiswa, serta para pelajar. Dengan berbagai macam alasan dan kepentingan atas kepemilikian smartphone. Munculnya istilah cybercomunity (masyarakat maya) dimana orang mampu berkomunikasi tanpa di batasi oleh ruang dan waktu melalui dunia maya, dan mendapatkan segala informasi dalam hitungan detik. Populernya smartphone karena menjadi sebuah kehidupan yang trendsentter saat ini, para konsumen terbawa oleh arus mode, termasuk menginginkan teknologi canggih seiring berkembangnya zaman. Industri budaya secara perlahan membuat masyarakat semakin menggemari produk-produk budaya kontemporer. Berbagai spesifikasi yang memadai dengan harga yang setara dengan kualitasnya, ditambah lagi imagenya sebagai ponsel kelas atas, maka masyarakat semakin berambisi untuk dapat memiliki smartphone.

Menurut Jean Baudillard (George Ritzer, 2013: 1) media massa telah mendorong dan mengeneralisasi proses simulasi dari pada realitas orang diperlakukan sebagai simulasi yang melibatkan rekombinasi konstan dari berbagai benda, elemenelemen kode. Penggunaan smartphone yang berkembang pesat di era globalisasi, sebagai alat komunikasi yang sangat diminati dan paling banyak digunakan oleh masyarakat terkusus oleh pelajar, dan bukan lagi menjadi komuditas yang sulit dicari, setiap bulan bermunculan berbagai produk baru baik dari hasil inovasi, modifikasi, maupun imitasi publik pun dibuat terpukau dengan kehadirannya.

Dengan menggunakan smartphone atau ponsel pintar ini yang memberikan kapastitas lebih besar dalam masyarakat dari berbagai kalangan terutama pada 
kalangan pelajar memudahkan untuk kegiatan proses belajar mengajar, meningkatkan minat belajar dan prestasi belajar siswa karena ruang belajar tidak hanya pada satu tempat sehingga melancarkan untuk tetap terhubung dengan jaringan kapan dan dimana saja. Memudahkan pelajar berinteraksi dan berkomunikasi dengan orang lain melalui smartphone, memudahkan untuk memperbanyak jaringan/link, memudahkan mendapatkan sumber-sumber pelajaran. Sebagai pengguna yang bijak diharapkan menggunakannya sesuai dengan kebutuhan serta tidak berlebih lebihan, sehingga teknologi canggih ini tidak terlepas dari nilai guna dan manfaatnya.

Menurut Raymond Williams (Mike Featherstone, 2008: 48), "salah satu pemakaian terbaru dari istilah mengkonsumsi adalah merusak (to destroy), memakai (to use up), membuang-buang (to waste), menghabiskan (to exhaust)". Dalam pengertian ini, konsumsi sebagai pembuang-buangan, perbuatan yang berlebihlebihan dan pengeluaran menunjukkan suatu kondisi parodoksikal dalam penekanan produksionis dari masyarakat kapitalis dan sosial negara yang harus dikontrol.

Masuknya smartphone di kalangan pelajar dengan berbagai faktor, dengan perlahan mereka menjadi korban dalam perkembangan teknologi. Smartphone bukan hanya sebagai wahana atau alat komunikasi, akan tetapi menjadikan sebuah ajang bergengsi yang menuntut semua pelajar untuk selalu mengikuti barang yang diminati banyak orang, serta menjadikan gaya hidup (life style). Adanya aplikasi seperti facebook, whasapp, bbm, dan wechat, bahkan games pun menjadi sebuah daya tarik untuk menggunakan smarphone. Menjadi sebuah prioritas dan penciptaan keuntungan yang sebesar-besarnya pada pemilik modal. Suatu totalitas, ide, 
perspektif, perilaku, citra dan fenomena lainnya yang dipilih dan diadopsi sebagai sebuah budaya, masuk menyentuh kebutuhan dalam lingkup libido, hasrat, dan ambisi. Budaya yang menuntun masyarakat lebih konsumtif, materialis dan cenderung bertingkah hedonis. Hal ini cenderung merusak tatanam aturan dan melanggar nilai-nilai budaya tradisioal.

Pelajar di sekolah sebagai subkultural dalam masyarakat yang merupakan suatu kelompok yang sangat rentan terpengaruh. Pola pikir remaja yang cenderung terbuka lebih mudah menerima hal-hal baru yang bersifat inovatif dibandingkan orangtua. Pelajar dalam pemakaian smartphone, mudah untuk menggunakan dan berkomunikasi dengan siapa saja, menghabiskan waktu berjam-jam, serta merusak atau berdampak bagi perilaku pelajar itu sendiri. Hal ini bisa memudarkan nilai-nilai dalam berinteraksi, serta merujuk pada pemuasan keinginan semata, mudah hilang, dan mengikuti kehidupan modern.

Perilaku sosial atau tindakan sosial Max Weber adalah tindakan individu sepanjang tindakan itu mempunyai makna atau arti subjektif bagi dirinya dan diarahkan kepada tindakan orang lain (Ritzer, 2010: 45). Sebagai makhluk sosial, manusia senantiasa akan hidup dengan melakukan tindakan-tindakan untuk mencapai tujuan tertentu. Tindakan mereka merupakan perbuatan, perilaku, atau aksi yang dilakukan oleh manusia sepanjang hidupnya guna mencapai tujuannya.

SMA Negeri 3 Makassar, berusaha melaksanakan dan memajukan pendidikan sesuai dengan tujuan pendidikan Nasional, yaitu mengembangkan potensi peserta didik agar menjadi manusia beriman, bertaqwa, berakhlak mulia, keterampilan untuk 
hidup mandiri, bertanggung jawab dan demokratis. Pada dasarnya mereka dapat dan mampu m ewujudkan apa yang diinginkan dalam sikap maupun perilaku serta dapat diterapkan di lingkungan formal, informal, maupun non formal.

Setelah dilakukan observasi awal, jumlah keseluruhan pelajar di SMA 3 Makassar adalah 986 pelajar, laki laki sebanyak 456 dan perempuan 531. Jumlah pelajar kelas X adalah 393, jumlah pelajar kelas XI adalah 303, dan jumlah pelajar kelas XII adalah 273. Tingkat penggunaan smartphone di kalangan mereka cukup tinggi, yakni 90\%, namun jika mengacu pada prestasi-prestasi akademik yang telah diraih sekolah tersebut. SMA Negeri 3 terbilang selalu meraih hasil maksimal dari semua ajang yang telah diikuti, baik di tingkat regional maupun provinsi.

Sekolah ini memiliki kebijakan tersendiri dalam penggunaan teknologi untuk metode pembelajarannya. Peneliti pernah mewancarai pelajar atas nama Annisa kelas X.9 mengatakan bahwa pengggunaan smartphone dibiarkan, hal ini disebabkan karena ada mata pelajaran yang bisa digunakan pada saat proses belajar berlangsung, namun ada pula mata pelajaran yang tidak diperbolehkan menggunakan apa lagi mengaktifkan, namun masih ada beberapa pelajar yang menggunakan, ini sebuah hasil praduga bahwa adanya perilaku yang tidak mengikuti peraturan dalam penggunaan smartphone. Serta adanya beberapa laporan pelajar masuk kepada Guru BK tentang penyalagunaan smartphone. Oleh sebab itu dalam penelitian ini akan melihat perilaku sosial pelajar dalam penggunaan smartphone, serta dampak, baik bersifat positif ataupun negatif dalam akademik maupun nonakademik. 
Berdasarkan latarbelakang masalah tersebut di atas, maka penulis tertarik untuk melakukan penelitian dengan mengangkat judul: “Teknologi dan Perilaku Sosial Pelajar (Studi Tentang Dampak Penggunaan Smartphone di SMA Negeri 3 Makassar ).”

\section{B. Rumusan Masalah}

Berdasarkan uraian dari latar belakang di atas, maka rumusan masalah yang dikemukakan dalam penelitian ini sebagai berikut:

1. Faktor-faktor apa yang mendorong pelajar SMA Negeri 3 Makassar Menggunakan smartphone?

2. Bagaimana gambaran perubahan perilaku sosial pelajar yang menggunakan smartphone di SMA Negeri 3 Makassar?

3. Bagaimana dampak penggunaan smartphone pada perilaku sosial pelajar di SMA Negeri 3 Makassar?

\section{Tujuan Penelitian}

Adapun tujuan penelitian ini adalah sebagai berikut:

1. Untuk mengetahui faktor-faktor yang mendorong pelajar SMA Negeri 3 Makassar menggunakan smartphone.

2. Untuk mengetahui gambaran perubahan perilaku sosial pelajar yang menggunakan smartphone di SMA Negeri 3 Makassar 
3. Untuk mengetahui dampak penggunaan smartphone pada perilaku sosial pelajar di SMA Negeri 3 Makassar

\section{Manfaat Penelitian}

Hasil peneltian ini diharapkan memberikan manfaat, antara lain:

\section{Manfaat Teoritis}

Hasil penelitian ini diharapkan mampu menambah khasanah ilmu pengetahuan tentang faktor serta bentuk perubahan perilaku sosial pelajar perubahan dan dampak penggunaan smartphone, serta dapat digunakan sebagai bahan referensi untuk peneliti-peneliti selanjutnya yang akan mengadakan penelitian mengenai judul yang hampir sama dengan ini.

\section{Manfaat Praktis}

Berdasarkan manfaat teoritis di atas, maka manfaat praktis penelitian ini adalah sebagai berikut:

a. Membangun kolektifitas solidaritas guru pelajar di SMA Negeri 3 makassar dalam memberikan pemahaman pemanfaatan teknologi smartphone untuk kemajuan belajar dan prestasi siswa.

b. Sumbangsi dan kontribusi nyata terhadap kritik sosial melalui serangkaian kegiatan ilmiah yang dituangkan dalam bentuk laporan hasil penelitian.

c. Rujukan atau bagi peneliti yang relevan 


\section{BAB II}

\section{TINJAUAN PUSTAKA}

\section{A. Teknologi}

Secara harfiah, teknologi berasal dari bahasa Yunani, yaitu "technologia" yang berarti pembahasan sistematik mengenai seluruh seni dan kerajinan. Istilah tersebut memiliki akar kata " techne" dan "logos", yang berarti perkataan atau pembicaraan, sedangkan kata "techne" dalam bahasa Yunani kuno berarti seni (art), atau kerajinan (craft). Dari makna harfiah tersebut, teknologi dalam bahasa Yunani Kuno dapat didefenisikan sebagai seni memproduksi alat-alat produksi dan menggunakannya.

Defenisi tersebut kemudian berkembang melalui ilmu pengetahuan yang menyesuaikan dengan kebutuhan manusia. Teknologi dapat pula dimaknai sebagai pengetahuan mengenai bagaimana membuat sesuatu (know-how of making things) atau "bagaimana membuat sesuatu" (know-how of doing things) atau bagaimana melakukan sesuatu" (know-how of doing things), dalam arti kemampuan untuk mengerjakan sesuatu dengan hasil nilai yang tiggi, baik nilai manfaat maupun nilai jualnya Raharjo, (2002).

Menurut Alisyahbana (Nanang Martono, 2014: 204) teknologi merupakan cara melakukan sesuatu untuk memenuhi kebutuhan manusia dengan bantuan alat dan akal, sehingga seakan-akan teknologi dapat memperpanjang, memperkuat, atau 
membuat lebih ampuh anggota tubuh, pancaindra, dan otak manusia. Teknologi bukan hanya merujuk pada prosedur yang diperlukan akan tetapi meliputi prosedur untuk memproduksi. Konsep teknologi baru yang menunjuk pada timbulnya suatu teknologi yang membawa dampak penting pada kehidupan sosial. Bagi orang yang hidup 500 tahun yang lalu, teknologi menunjuk pada proses percetakan, sedangkan pada masa sekarang, teknologi menunjuk pada komputer, satelit, pesawat, atau teknologi komunikasi.

Pada dasarnya teknologi adalah perangkat yang berharga karena dapat memberikan berbagai manfaat baik secara langsung maupun tidak langsung. Pengetahuan tentang teknologi ini sangat penting, hal ini disebabkan karena (1) Teknologi berada dimana mana (2) Teknologi dapat membantu manusia menjadi lebih produktif (3) Teknologi itu menggairahkan dan dapat memberikan perubahan (4) Teknologi mempertinggi karir.

Menurut Jead Baudrillard (Nanang Martono, 2014: 216), teknologi adalah simbol kemajuan, siapa saja yang memanfaatkan teknologi, maka dalam dirinya akan tercermin sebuah kemajuan, Baudrillard menjelaskan makna teknologi bagi status individu dalam masyaratakat modern, selain sebagai simbol kemajuan, teknologi juga menjadi simbol status bagi pemakainya, hal ini lebih disebabkan pada makna simbol yang melekat pada teknologi tersebut. Teknologi akan menyiratkan semua simbolsimbol atau tanda status yang dapat diptontonkan kepada khalayak.

Melalui iklan bagi Baudrillard adalah kepanjangan tangan kapitalis yang mudah dikendalikan dan mudah mengendalikan pasar. Melalui iklan setiap produk 
dapat ditawarkan dengan berbagai cara yang cukup meggoda selera konsumen dan konsumen. Seolah-olah diombang-ambing dengan berbagai penawaran dalam iklan, menwarkan kelebihan produk namun iklan tidak pernah bertanggung jawab atas segala resiko yang timbul dari iklan tersebut. Iklan pula menawarkan mitos, misalkan mitos kenikmatan, sehingga konsumen akan digiring untuk mengonsumsi produk agar tampil beda.

Menurut Aguste Comte (Nanang Martono 2014: 207), pendapatnya mengenai positivisme, akan atau rasio manusia yang mengalami perkembangan. Secara evolusioner merupakan modal awal bagi manusia untuk menghadapi berbagai persoalan hidup yang dihadapinya. Teknologi sebagai hasil perkembangan rasio manusia dan menjadi sebuah simbol peradaban. Akan tetapi ketika manusia mulai mendewakan akal, teknologi pada akhirnya justru diposisikan sebagai "tuhan" bagi manusia modern, manusia menjadi hamba bagi teknologi, manusia menjadi sangat bergantung pada teknologi. Dengan menguasai teknologi seolah-olah manusia telah mampu menguasai dunia.

Teknologi dapat diposisikan sebagai faktor yang turut melemahkan hubungan antar individu dalam kelompok sosial. Selain itu teknologi pula melahirkan gaya hidup yang berubah, dan teknologi telah mempengaruhi pola pikir manusia itu sendiri. Akibatnya secara tidak langsung teknologi juga sangat mempengaruhi tindakan dan perilaku manusia. Tekologi menjanjikan (1) perubahan, (2) kemajuan, (3) kemudahan, (4) peningkatan produktivitas, (6) ketepatan dan kecepatan dan (7) popularitas. Teknologi menjadi salah satu faktor perubahan dalam masyarakat, baik 
dari sisi perubahan kebutuhan serta perilaku manusia dalam penggunan teknologi khsususnya smartphone.

\section{B. Penggunaan Smartphone pada Pelajar}

Salah satu produksi dari teknologi komunikasi dan informasi yakni smartphone. Alat yang dapat membantu untuk memproses dan mengirim data dari satu perangkat ke perangkat yang lainnya. Serta merupakan alat yang juga menambah kemampuan seseorang dalam berkomunikasi antar sesama. Komunikasi sangat berkaitan dengan perkembangan teknologi yang berperan sebagai teknis digunakan untuk memproses dan menyampaikan informasi. Teknologi informasi sendiri adalah hasil dari pemanfaatan teknologi yang membantu manusia dalam membuat, menyimpan dan menyebarkan suatu informasi (Abdul Kadir \& Terra CH. Triwahyuni 2003: 5)

Teknologi smartphone berasal dari bahasa Inggris yaitu ponsel cerdas adalah telepon genggam yang mempunyai kemampuan dengan penggunaan dan fungsi yang menyerupai komputer, perangkat telekomunikasi serbaguna. Telpon yang bekerja menggunakan seluruh perangkat lunak sistem operasi yang menyediakan hubungan standar yang mendasar bagi pengembang aplikasi. Ponsel cerdas merupakan sebuah telepon yang menyajikan fitur-fitur canggih yang dapat dikatakan sebagai komputer kecil yang mempunyai kemampuan sebuah telepon. Suatu alat komunikasi atau telepon selular yang dilengkapi dengan organizer digital. Smartphone merupakan 
pengembangan dari telepon selular yang kemudian ditambahkan fitur dan fasilitas lainnya sehingga menjadi telepon yang cerdas dan disebut Smartphone

Menurut Gary b, Thomas J dan Misty E (2007: 139), samrtphone adalah telepon yang bisa dipakai internetan yang biasanya menyediakan fungsi Personal Digital Assistant (PDA). Seperti fungsi kelender, buku agenda, buku alamat, kalkulator, dan catatan. Menurut David Wood Wakil Persiden Eksekutif Pt Symbian OS, telpon pintar dapat dibedakan dengan telpon genggam biasa dengan cara fundamental: bagaimana mereka di buat dan apa yang nereka bisa lakukan (http:elib.unikom.ac.id/fles/disk1/642/jbptunikompp-gdl-ernisuryan-32065-8unicom_e-i-pdf)

Selain itu telepon cerdas ini dikategorikan sebagai fungsi pengatur personal yang lengkap, miniatur papan ketiknya, ada yang menggunakan layar sentuh, kamera, kemampuan membaca dokumen, penjelajah foto, melihat video, menjelajah internet. Fitur yang sering ditemukan adalah kemampuannya menyimpan daftar nama sebanyak mungkin tidak seperti telpon genggam biasa yang mempunyai batasan maksimum penyimpanan daftar nama. Sistem operasi yang ditemukan di ponsel cerdas ini misalkan RIM blackberry, windows mobile, linux, android. Dalam perkembangan teknologi komunikasi dan informasi memiliki segmentasi yang secara umum bisa dikelompokan menjadi tiga kelas yaitu telepon cerdas kelas atas yang memiliki spesifikasi perangkat keras yang sangat tinggi, memiliki fitur unggulan dan bergengsi yang berkisar 4 juta sampai 10 juta, telpon cerdas kelas menengah yang canggih dengan harga yang lebih rendah, namun cukup banyak peminatnya, dan 
telepon cerdas kelas bawah yang semakin banyak peminatnya dengan harga terjangkau.

Di kalangan masyarakat terutama bagi pelajar mengenal beberapa brand ternama yang menguasai smartphone diantaranya adalah (1) Iphone, lebih mengedepankan sisi kemewahan dari smartphone terutama tampilan luar dan juga komponen yang ada didalamnya. Memiliki keunggulan di sisi design serta menjadi produk elegan dan menawarkan kemampuan multimedia yang baik. Membuat ribuan aplikasi untuk games, musik, video, sosial networking, internet dan beragam aplikasi lainnya yang mampu memberikan kepuasan tersendiri bagi penggunanya. (2) Blackberry, yang sangat banyak digunakan oleh masyarakat, desain yang berbeda dari yang lain disertai fitur BBM (blackberry Messenger) yang hanya terdapat pada Blackberry saja.

Barang mewah ini awalnya hanya dimiliki oleh kalangan menengah ke atas, namun seriing berjalannya waktu harga smartphone ini pun semakin bisa dijangkau semua kalangan. Fitur BBM merupakan faktor pendobrak mewahnya pengguna Blackberry (3) Geogle Anroid, mencoba menarik pasar dengan fitur yang mirip iphone dan juga keunggulanya yaitu anroid hadir dengan Plactform Open Source yang memberikan akses kepada para devoloper untuk dapat bebas menciptakan aplikasi dalam smartphone ini. Keunggulan anroid pengguna bebas mengutak atik smartphone miliknya. Ada pun beberapa fitur dalam smartphone yaitu geoogle, facebook, path, twitter, instagram, line, youtube, BBM, dan banyak lainnya. 
Perbedaan hendphone dan smartphone, yaitu pada handphone tidak memiliki operating system (OS) sedangkan smartphone menggunakan Operation system (OS). Jika handphone menggunakan software (perangkat lunak) penyimpanan data/dokumen terbatas sedangkan pada smatrphone menggunakan software (perangkat lunak) atau penyimpanan data/dokumen tidak terbatas. Perihal kecepatan akses, pada handphone kecepatan akses internet terbatas sementara pada smartphone kecapatan akses internetnya tidak terbatas atau cepat.

Perbedaan antara handphone dan smartphone juga terlihat pada perangkat kerasnya yaitu pada tombol. Tombol yang digunakan handphone bukan model QWERTY sementara pada smartphone menggunakan tombol QWERTY yang diadaptasi dari keybord komputer. Perbedaan yang terakhir adalah pada proses pengaksesan pada internet. Handphone tidak dapat mengakses e-mail sedangkan smartphone dapat mengakses e-mail dan memiliki notifikasi. Dalam kalangan pelajar terdapat beberapa faktor yang mendorong untuk menggunakan teknologi (Monle Lee dan Carla Jhonson, 2004: 113).

\section{Faktor yang Mendorong Sehingga Menggunakan Smartphone}

a. Faktor-faktor pribadi

Faktor pribadi dalam keputusan untuk menggunakan smartphone, seperti dilihat dari keadaan demografis, berupa karakteristik-karakteristik individual seperti usia, jender, tingkat pendidikan, pekerjaan, dan pendapatan. Berdasarkan perbedaanperbedaan itulah yang cenderung membuat pilihan berbeda menyangkut penggunaan smartphone. 


\section{b. Faktor-faktor psikologis}

\section{Persepsi}

Dalam penggunaan sebuah barang terkhusus smartphone, para pengguna memiliki persepsi yang berbeda-beda dalam sebuah informasi barang atau produk. Meskipun barang yang dipasarkan melalui media tidak dapat mengendalikan persepsi orang, hanya saja sering kali mencoba mempengaruhinya. Munculnya sebuah produk melalui iklan-iklan menjangkau konsumen di bawah ambang kesadaran yang telah memebesar-besarkan akibat frekuensi praktik -praktik tersebut.

Pelajar dalam penggunaan smartphone memiliki persepsi yang berbeda-beda dalam penggunaannya, hadirnya smartphone yang melalui iklan-iklan sangat mempengaruhi untuk membeli dan memanfaatkannya.

\section{Motivasi}

Dorongan dalam diri yang menggerakkan para konsumen memenuhi bayangan akan sebuah kebutuhan disebut motivasi. Kebutuhan dasar manusia merentang dari kenyamana peneerimaan sosial hingga kebutuhan akan cinta, seks, dan kekuasaan. Para pengiklan ingin mengetahui apa yang memotivasi para konsumen sehingga mereka menuruti motif tersebut. Adanya sebuah keinginan sendiri untuk mengunakan sebuah produk smartphone, para pelajar tertarik karena menurutnya adalah sebuah kebutuhan mendasar yang sangat menunjunkan dalam kehidupan sehari-hari. 


\section{Sikap}

Seseorang termotivasi untuk memenuhi satu kebutuhan, cara mereka bergantung pada sikap terhadap berbagai alternatif. Sikap adalah evaluasi berkelanjutan, persaan, dan kecenderungan perilaku individu terhadap sebuah objek atau gagasan. Para pemasar secara seksama mengukur sikap konsumen terhadap iklan, desain pemasaran, harga, dan ciri produk untuk memastikan kesuksesan di pasar.

Pengambilan keputusan terkhusus pelajar dalam menggunakan smartphone baik berbagai merek atau tipe maupun berbagai harga tergantung pada sikap mereka.

\section{Gaya hidup}

Sikap para konsumen dapat mempengaruhi gaya hidup yang mereka adopsi. Gaya hidup dapat didefenisikan sebagai kegiatan, minat, opini, dan pola konsumsi seseorang. Para pemasar biasanya menggunakan informasi gaya hidup untuk menyesuaikan bauran pemasaran agar memenuhi kebutuhan konsumen.

Para pelajar tidaklah ingin menjadi sebuah generasi yang ketinggalan terutama dalam sebuah perkembangan teknologi, mereka akan mengikuti yang populer di masanya, mendegar opini kecanggihan yang dimiliki oleh smartphone, sehingga mempengaruhi pembelian.

c. Faktor sosial

1. Budaya

Keyakinan, nilai, dan simbol yang muncul dari masyarakat diteruskan ke generasi berikutnya telah membentuk sebuah budaya. Adanya kebijakan Sekolah 
untuk menggunakan smartphone sebagai penunjang dalam proses belajar mengajar, menimbulkan sebuah kepuasan tersendiri namun melahirkan nilai-nilai dan budaya yang baru terutama dalam kehidupannya masing-masing.

\section{Kelompok-kelompok rujukan}

Sebagai tambahan bagi budaya, perilaku pembeli dapat dipengaruhi oleh sebuah kelompok rujukan, termasuk keluarga, teman, dan organisasi-organisasri profesional. Kelompok ini bisa terdiri dari satu atau lebih orang yang memberikan pengaruh langsung terhadap pengambilan keputusan sang pembeli. Kelompok rujukan mempengaruhi keputusan orang lewat pemberian informasi atau lewat penekanan untuk mengikuti norma-norma kelompok. Efek optimal dari kelompok rujukan terjadi saat para konsumen tidak begitu mengenali sebuah produk.

Dalam penggunaan smartphone bukan hanya dipengaruhi oleh keinginan dari dalam diri sendiri melainkan adanya teman-teman atau orang-orang yang mampu mempengaruhi dalam penggunaannya.

\section{Status sosial}

Status sosial adalah satu faktor penting lain dalam perilaku pembeli. Para konsumen di setiap negara terdiri dari berbagai kelas sosial yang berbeda. Kelas sosial adalah sebuah kelompok individu dengan peringkat sosial yang serupa (misalnya, tingkat pendapatan atau keahlian yang serupa). Dalam kelas sosial menentukan tipe, kualitas dan kualitas produk yang dibeli dan digunakan. Pengguna Smartphone terutama pada pelajar, menggunakan dengan berbagai macam tipe atau 
merek Smartphone, hal ini karena daya dukung keluarga yang memiliki ekonomi untuk membelikannya, serta keikutsertaan oleh teman-temanya.

\section{Perubahan Perilaku Sosial Pelajar}

Perilaku sosial adalah suasana saling ketergantungan yang merupakan keharusan untuk menjamin keberadaan manusia (Ibrahim 2001: 26). Sebagai bukti bahwa manusia dalam memenuhi kebutuhan hidupnya tidak dapat melakukan sendiri melainkan memerlukan bantuan orang lain. Ada kaitan saling ketergantungan diantara satu orang dengan yang lainnya.

Berbagai bentuk jenis perubahan perilaku sosial seseorang dapat diamati ketika seseorang berinteraksi dengan orang lain. Seperti dalam kehidupan berkelompok, kecenderungan perilaku sosial seseorang yang menjadi anggota kelompok akan terlihat jelas di antara anggota kelompok yang lainnya. Perilaku sosial dapat dilihat melalui sifat-sifat dan respon antar pribadi, yaitu:

1. Kecenderungan perilaku peran

a. Sifat pemberani dan pengecut secara sosial

Orang yang memiliki sifat pemberani secara sosial, biasanya dia suka mempertahankan dan pembela haknya, tidak malu-malu atau tidak segan melakukan sesuatu perbuatan yang sesuai norma di masyarakat dalam membela haknya dalam mengendepankan kepentingan diri sendiri sekuat tenaga. Sedangkan sifat pengecut menunjukkan perilaku atau keadaan sebaliknya, seperti kurang suka 
mempertahankan haknya, malu dan segan beruat untuk mengedepankan kepentingannya.

b. Sifat berkuasa dan sifat patuh

Orang yang memiliki sifat seolah berkuasa dalam perilaku sosial biasanya ditunjukkan oleh perilaku seperti bertindak tegas, berorientasi kepada kekuatan, percaya diri, berkemauan keras, suka memberi perintah dan memimpin langsung. Sedangkan sifat yang patuh atau penyerah menunjukkan perilaku sosial yang sebaliknya, misalkan kurang tegas dalam bertindak, dan tidak suka memberi perintah

c. Sifat inisiatif secara sosial dan pasif

Orang yang memeiliki sifat inisiatif biasanya suka mengorganisasi kelompok. Tidak suka mempersoalkan latarbelakang, suka memberi masukan atau saran-saran dalam berbagai pertemuan, dan biasanya suka mengambil alih kepemimpinan. Sedangkan sifat orang yang pasif secara sosial ditunjukkan oleh perilaku yang bertentangan dengan sifat orang yang aktif, misalnya perilaku diam, kurang berinisiatif, tidak suka memberi saran atau masukan.

d. Sifat mandiri dan tergantung

Orang memiliki sifat mandiri biasanya membuat segala sesuatunya dilakukan oleh dirinya sendiri. Seperti membuat rencana sendiri, melakukan sesuatu dengan cara-cara sendiri tidak suka berusaha mencari nasihat atau dukungan orang lain, dan secara emosional cukup stabil. Sedangksn sifat yang 
ketergantungan cenderung menunjukkan perilaku sosial sebaliknya dari sifat orang mandiri misalkan melakukan rencana segala sesuatu harus mendapatkan saran.

2. Kecenderungan perilaku dalam hubungan sosial

a. Dapat diterima atau ditolak oleh orang lain

Orang memeliki sifat yang dapat diterima oleh orang lain biasanya tidak berprasangka buruk, loyal, dipercaya, pemaaf, dan tulus menghargai orang lain. Sementara sifat yang orang ditolak biasanya suka mencari kesalahan dan tidak mengakui kelebihan orang lain.

b. Suka bergaul dan tidak suka bergaul

Orang suka bergaul biasanya memiliki hubungan sosial yang baik, senang bersama dengan orang lain dan senang bepergian, sedangkan orang tidak suka bergaul menunjukkan sifat dan perilaku yang sebaliknya.

c. Sifat ramah dan tidak ramah

Orang biasanya ramah, periang, hangat terbuka, mudah di dekati orang, dan suka bersosialisasi, orang tidak ramah akan sebaliknya.

d. Simpatik atau tidak simpatik

Orang yang memiliki sifat simpatik biasanya peduli terhadap perasaan dan keinginan orang lain, murah hati dan suka membela orang tertindas. Sedangkan otang tidak bersifat simpatik akan sebaliknya.

3. Kecenderungan periku agresif

a. Sifat suka bersaing dan tidak suka bersaing 
Orang yang suka bersaing suka menganngap sosial sebagai perlombaan lawan adalah saingan yang harus dikalahkan, memperkaya diri sendiri. Sedangkan orang tidak suka bersaing (bekerja sama) menunjukka sifat sebaliknya.

b. Sifat agresif dan tidak agresif

Biasanya suka menyerang orang lain baik secara langsung maupun tidak langsung, pendendam atau tidak patu pada pemimpinnya, sedangkan tidak agresif akan bersifat sebaliknya.

c. Sikap kalem, atau tenang secara sosial

Orang yang kalem biasanya tidak nyaman jika berbeda dengan orang lain, mengalami kegugupan, malu, ragu dan merasa terganggu jika di tonton orang.

d. Sifat pamer atau menonjolkan diri

Suka bersifat berlebihan, mencari pengakuan, berprilaku aneh untuk mencari perhatian orang lain.

\section{Dampak Penggunaan Teknologi Smartphone Pada Pelajar}

Satu hal yang mendapat perhatian khusus adalah bahwa setiap perkembangan teknologi selalu menjanjikan kemudahan, efesiensi, serta peningkatan produktivitas. Pada awalnya teknologi diciptakan untuk mempermudah pekerjaan. Terutama pada pelajar sekali pun, namun dibalik semua itu memiki pula dampak negatif. Nanang Martono (2014: 217) membagi beberapa dampak positif bagi penggunaan teknologi, yakni

1. Menjanjikan perubahan, setiap penemuan baru akan melahirkan berbagai perubahan dalam masyarakat. Ibarat sebuah subsistem, kehadiran teknologi baru 
sebagai subsistem baru dalam masyarakat akan membawa berbagai konsekuensi, teknologi mengubah pola aktivitas sehari-hari, subsistem yang mau tidak mau harus menyesuaikan diri akibat kehadiran teknologi tersebut.

2. Menjanjikan kemajuan, teknologi adalah simbol kemajuan, siap yang mampu mengakses teknologi, maka ia akan mengalami sedikit atau banyak kemajuan , seseorang tidak akan ketinggalan informasi manakalh ia mengenggam sebuah teknologi.

3. Menjanjikan kemudahan, teknologi memang diciptakan untuk memberikan kemudahan bagi individu. Tedak perlu susah menghubungi sanak keluarga di luar kota, ahkan di luar negeri mereka cukup menekan beberapa nomor melalui handphone atau smartphone .

4. Peningkatan produktivitas, teknologi menjadikan sebuah pekerjaan yang lebih efisiensi dan peningkatan produktivitas dari pada harus mempekerjakan tenaga manusia yang memakan banyak waktu.

5. Kecepatan dan ketepatan, berbagai pekerjaan dapat diselesaikan dengan tepat manakala kita memanfaatkan teknologi.

6. Meningkatkan popularitas, teknologi seperti dalam internet mampu mempasilitasi setiap orang bergaya, kita dapat berprilaku narsis hanya dengan berbekalan kamera, modem untuk dapat mengunggah rekaman gambar kita.

Adapun dampak negatif terhadap penggunaan teknologi smartphone 
1. Teknologi mengancam terjadinya pemanasan global, nafsu manusia untuk memanfaatkan teknologi berbahaya semakin merajela dengan alasan-alasannya yang semakin memperparah kondisi bumi.

2. Mengakibatkan kecanduan pada beberapa orang yang menggunakan teknologi mengakibatkan gangguan sosial dan psikologis.

3. Teknologi menciptakan ketegangan antarmanusia, peperangan seruing terjadi, perkelahian, telah menciptakan arogansi sosial, keserakahan, peperangan menjadi ajang pertunjukan kekuatan dan penguasaan teknologi.

4. Menciptakan ketidaknyamanan. Teknologi membawa berbagai resiko, kenyamanan manusia menjadi terusik dengan kehadiran teknologi. Setiap saat waktu manusia dihabiskan untuk melayani teknologi

\section{Perilaku Sosial}

Perilaku sosial dapat didefinisikan sebagai perilaku dari dua orang atau lebih yang saling terkait atau bersama dalam kaitan dengan sebuah lingkungan bersama sering dikatakan bahwa prilaku sosial berbeda dari perilaku individual dan bahwa ada"situasi sosial" dan "kekuatan sosial" yang tidak dapat digambarkan dengan bahasa ilmu pengetahuan alam. Menurut B.F. Skinner (2013: 459).

Perilaku muncul karena satu organisme penting bagi organisme lainnya sebagai bagian dari lingkungannya oleh karena itu langkah pertama adalah menganalisis lingkungan sosial dan bagian-bagian khas yang mungkin dimilikinya. Sebagai makhluk sosial, seorang individu sejak lahir hingga sepanjang hayatnya 
berhubungan dengan individu lainnya atau dengan kata lain melakukan relasi interpersonal. Dalam relasi interpersonal itu ditandai dengan berbagai aktivitas tertentu, baik aktivitas yang dihasilkan berdasarkan naluri semata justru melalui proses pembelajaran tertentu. Berbagai aktivitas individu dalam relasi interpersonal ini biasa disebut perilaku sosial.

Mengenai teori perilaku Max Weber atau sering kita dengar dengan tindakan sosial, sebelumnya kita melihat, pengertian sosiologi menurut Max Weber yaitu sosiologi sebagai ilmu institusi-istitusi sosial, sosial Weber adalah ilmu tentang perilaku sosial. Menurutnya terjadi pergeseran, tekanan kearah keyakinan, motivasi, dan tujuan pada diri di anggota masyarakat, yang semuanya memberi isi dan bentuk kepada kelakuannya. Kata perikelakuan di gunakan oleh Weber untuk perbuatanperbuatan yang bagi si pelaku mempunyai arti subjektif, mereka dimaksudkan hendak mencapai suatu tujuan, atau dorongan motivasi. Perikelakuan menjadi sosial menurut Weber terjadi hanya kalau dan sejauh mana arti maksud subjektif dari tingkah laku membuat individu memikirkan dan menunjukkan suatu kesaragaman yang kurang lebih tetap.

Pelaku individual mengarahkan kelakuannya kepada penetapan-penetapan atau harapan-harapan tertentu yang berupa kebiasaan umum atau dituntut dengan tegas atau bahkan dibekukan dengan undang-undang. Orang yang dimotivir untuk membalas atas suatu penghinaan dimasa lampau, memorientasikan tindakannya kepada orang lain. Menurut Weber kelakuan sosial berakal dalam kesadaran individual dan bertolak dari situ. Tingkah laku individu merupakan kesatuan analisis 
sosiologis. Weber berpendapat bahwa studi kehidupan sosial yang mempelajari pranata sosial dari luar saja, seakan tidak ada inside story, dan karena itu mengesampingkan pengarahan diri oleh individu, tidak mengjangkau unsur utama dan pokok dari kehidupan sosial itu.

Menurut Weber sebagaimana ditegaskan K.J. Veeger (1990) membagi perilaku sosial atau tindakan sosial menjadi 4 bagian yaitu:

a. Kelakuan yang di arahkan secara rasional, kepada tercapainya suatu tujuan.

b. Kelakuan sosial yang berorientasi pada nilai. Nilai-nilai disini bisa berarti keindahan.

c. Kelakuan yang menerima orientasi dari perasaan atau emosi, atau orang yang melampiaskan nafsu.

d. Tindakan tradisional yang dimaknai sebagai tindakan yang tidak memperhitungkan pertimbangan rasional.

Adapun beberapa konsep dalam perilaku sosial yakni:

1. Atensi, yaitu suatu sikap seseorang yang ingin di perhatikan.

2. kesadaran, yaitu suatu tindakan yang dilakukan secara sadar supaya dikatakan berpenampilan nyentrik atau tampak berbeda dengan penampilan yang lainnya.

3. persepsi, yaitu suatu kesadaran ingin tampil mempersepsikan diri, dan kemauan mempersepsikan sesuatu.

Dalam perilaku sosial yang dilakukan, terkadang ada beberapa hal yang melatar belakangi. Mengapa sikap seseorang bisa terbentuk, apakah dia di pengaruhi 
oleh dirinya sendiri atau orang lain. Seperti yang diungkapkan oleh Sigmund Freud dia mengatakan bahwa perilaku sosial seseorang dilandasi oleh adanya pertarungan antara Id Ego dan super Ego. Id dimaknai sebagai suatu kemauan seseorang yang di dorong oleh sikap biologis, seperti kesenangan semata. Ego dimaknai sebagai suatu perilaku yang berlandaskan pada adanya moral, seperti menjaga nama baik dirinya dalam berperilaku. Sedangkan Super Ego dapat dimaknai sebagai suatu perilaku yang dilakukan terhadap orang lain yang di dasari oleh internalisasi norma-norma sosial dan kebudayaan masyarakatnya

Begitupun juga menurut Ritzer mengatakan perilaku sosial memusatkan perhatiannya kepada hubungan antara individu dan lingkungannya yang terdiri atas bermacam-macam objek sosial dan non sosial. Pokok dari paradigma ini adalah tingkah laku individu yang berlangsung dalam hubungannya dengan faktor lingkungan yang mengahasilkan akibat-akibat atau perubahan terhadap tingkah laku (Ritzer, 2010: 37). Bagi paradigma perilaku sosial, individu kurang sekali memiliki kebebasan.Anggapan yang diberikannya ditentukan oleh sifat dasar stimulus yang datang dari luar dirinya, dari tingkah laku manusia lebih bersifat mekanik.

\section{Landasan Teori}

\section{Teori Interaksionisme Simbolik}

Dalam menyelesaikan permasalahan yang ada, peneliti menggunakan teorinya George Herber Mead yaitu Intraksionisme simbolik. Bahwa kenyataan sosial George 
Herber Mead atau apa yang bisa di amati melalui adanya simbol atau lambing. Adapun pemikiran dari Mead dapat dipahami melalui konsep diri dan organisasi ( Doyle Paul Jhonson, 1986: 17) yaitu:

a. Konsep diri, dapat dipahami sebagai sebuah pertanyaan tentang siapa aku menjelaskan tentang adanya sadar diri, konsep sadar diri menggambarkan bahwa keberadaannya dengan orang lain dalam hal berinteraksi. Menjelaskan bahwa dirinya bagian dari orang lain dimana dirinya terlibat dengan orang lain.

b. Organisasi, dapat dipahami sebagai kesadaran individu mengenai keterlibatannya dengan orang lain secara khusus dalam seperangkat hubungan sosial yang sedang berlangsung atau dalam suatu komunitas yang sedang berlangsung (organisasi). Kesadaran ini merupakan hasil dari proses refleksi yang tidak kelihatan dimana individu itu melihat tindakan-tindakan pribadi atau bersifat potensial dari titik pandangan orang lain dengan siapa individu itu berhubungan.

Dari adanya kedua konsep yang dibangun dan dikembangkan oleh George Herber Mead. Bahwa hal yang terpenting untuk dipahami dalam interaksi simbolik yaitu bagaimana simbol itu dapat dipahami melalui konsep diri atau sadar diri dengan organisasi atau hubungan diri tersebut dengan sekelompok orang atau komunitas di dalam masyarakat. Contoh orang melakukan sebuah aktifitas hubungan dengan orang lain atau organisasi karena adanya tujuan atau kepentingan tertentu (Margaret Archer, 
2011: 3). Begitupun juga dalam menganalisis bagaimana penggunaan smartphone dapat dipahami melalui perilaku yang dilakukan oleh siswa SMA Negeri 3 Makassar.

Dari gambaran di atas dalam teori Interaksi Simbolik menjelaskan perilaku seseorang terbentuk oleh adanya sebuah simbol. Mereka berinteraksi melalu simbol signifikan seperti selain dari smartphone itu sendiri melalui media atau aplikasiaplikasi yang ada pada smartphone, seseorang mampu berkomunikasi melalu dunia maya, dan berinteraksi, mampu membuka dan mendonwload aplikasi games dengan gratis, sehingga mengakibatkan ketergantungan dan berdampak pada perilaku sosial mereka. Simbol-simbol yang terdapat pada Smartphone merupakan sebuah fenomena sosial yang muncul akibat berkembangnya teknologi informasi dan komunikasi dan bentuk jaringan sosial yang luas tanpa batas ruang dan waktu.

Tentang perilaku sosial Max Weber atau disebut juga tindakan sosial, sebelumnya menurut Max Weber tentang sosiologi mendefenisikan sebagai ilmu tentang institusi-intitusi sosial, sosiologi Weber adalah ilmu tentang perilaku sosial. Menurutnya terjadi suatu pergeseran tekanan kearah keyakinan, motivasi dan tujuan pada diri anggota masyarakat yang semuanya memberi dan membentuk kepada kelakuannya. Tindakan sosial Max Weber adalah tindakan individu sepanjang tindakan itu mempunyai makna atau arti subjektif bagi dirinya dan diarahkan kepada tindakan orang lain (Ritzer, 2010: 45).

Dalam hidup masyarakat, akan mengadakan hubungan dengan orang lain. Hubungan dalam sosiologi disebut interaksi sosial. Interaksi sosial merupakan hal 
yang pokok dari kehidupan sosial, hal mendasari interaksi sosial adalah tidakan sosial. Setiap hari manusia melakukan tindakan dengan maksud dan tujuan tertentu. Tindakan itu umumnya berkaitan dengan orang lain, mengingat kodratnya sebagai makhluk sosial.

Menggunakan smartphone dengan tujuan agar pelajar memudahkan untuk berkomunikasi dengan temannya adalah salah satu contoh. Menggunakan kecanggihan teknologi, mampu mengeprasikan media-media yang digunakan, serta mengikuti perkembangan teknologi informasi global. Tidak semua tidakan manusia dapat dianggap sebagai tindakan sosial. Dalam kaitan dengan perilaku pelajar sebagai dampak menggunakan smartphone, merupakan bentuk tindakan sosial, karena rasa ingin tahu, naluri yang menggoda dari dalam diri serta lingkungannya. Olehnya itu dapat diartikan bahwa tindakan sosial adalah suatu tindakan yang dilakukan dengan beriorentasi pada diri serta dipengaruhi oleh orang lain.

Teori tindakan mempunyai asumsi bahwa manusia pada umumnya rasional, bahwa mereka bertindak dengan mempertimbangkan bahwa hal tersebut adalah baik bagi mereka. Namun rasionalitas dalam jenis tindakan Weber ini tidak terbatas pada pengertian yang sempit untuk memaksimalkan keuntungan sebagaimana ketika digunakan dunia ekonomi. Seseorang yang melakukan sesuatu karena mengikuti kebiasaan mungkin merupakan suatu yang sangat rasional ketika mengacu pada rasionalitas tindakan dalam pandangan Weber.

Kelakuan sosial menurut Weber juga berakar dalam kesadaran individual dan bertolak dari situ tingkah laku individu merupakan kesatuan analisis sosiologi. Weber 
berpendapat bahwa studi kehidupan sosial yang mempelajari pranata dan struktur sosial dari luar saja, seolah-olah tidak ada inside-stiry dan karena itu mengesampingkan pengarahan diri oleh individu, tidak menjangkau unsur utama dan pokok dari kehidupan sosial itu. Sosiologi harus berusaha menjelaskan kelakukan manusia dengan menyelami dan memahami seluruh sistem subjektif.

Para tokoh teori tindakan (action theory) pada umumnya memberikan perhatian pada struktur sosial yang mempengaruhi tindakan individu dan yang pada gilirannya dibentuk olehnya. Sementara pada strukturalis mengidentifikasi struktur sosial melalui dan menggambarkan struktur sosial tersebut dengan tindakan individu.

Weber memfokuskan teorinya pada tindakan yang beriorentasi pada tujuan dan motivasi pelaku yang bukan hanya melihat dari skala kecil masyarakat yaitu individu. Masyarakat mampu membandingkan struktur, beberapa masyarakat dengan memahami alasan-alasan mengapa warga masyarakat bertindak, kejadian di masa lalu yang mempengaruhi karakter mereka, dan memahami tindakan para pelakunya yang hidup di masa kini, tetapi tidak mungkin menggeneralisasi semua masyarakat atau semua struktur sosial. Weber memusatkan perhatiannya pada tindakan yang jelasjelas melibatkan campur tangan proses pemikiran (dan tindakan bermakna yang ditimbulkan olehnya) antara terjadinya stimulus (pemicu atau penggerak) dengan respon (reaksi).

Penyesuaian diri terjadi secara berangsur-angsur, seiring dengan pengetahuan yang berkembang serta penerimaan individu terhadap nilai-nilai dan norma-norma yang berlaku. Dalam keadaan normal, lingkungan yang berhubungan dengan pelajar 
adalah keluarga yang merupakan media sosialisasi pertama yang biasa disebut sosialisasi primer dalam pergaulan sehari-hari. Media teman sepermainanya, seorang pelajar akan berinteraksi dengan teman sebayanya, dimana pelajar mempelajari peraturan yang mengatur orang-orang yang kedudukannya sejajar. Dimana mulai mempelajari nilai keadilan, semakin meningkat umurnya semakin penting pengaruh kelompok sepermainnya. Kadang kala terjadi konflik antara apa yang didapatkan di dalam keluarga dengan apa yang diterima oleh teman-temanya. Terutama pada masyarakat yang berkembang dengan amat dinamis, hal ini dapat menjurus pada tindakan yang bertentangan dengan moral masyarakat lainnya.

Pada usia remaja yang berkisar umur 15 sampai 18 tahun kelompok sepermainan yang berkembang menjadi kelompok persahabatan yang luas. Disebabkan karena bertambahnya ruang lingkup pergaulannya terkhusus di sekolah bahkan diluar sekolah, namun hal demikian perlu diwaspadai dengan adanya pengaruh-pengaruh dari teman sebayanya tersebut. Pada masa remaja tingkat kewaspadaan sangat tinggi. Para pelajar akan mudah terpengaruh apabila didikan moral dari orang tua sejak awal sangat lemah. Olehnya itu sebelum mereka keluar dari lingkungan keluarga masuk kepada lingkungan sebayanya, sosialisasi keluarga sebaiknya diperkuat dan mendalam.

Sosialisasi merupakan proses pembelajaran, yang didapatkan bukan hanya di lembaga formal namun pada lembaga non formal. Bahkan pada masyarakat luas pun melalui pengalaman-pengalaman yang didapatkannya. Dimaksud pembelajaran adalah modifaksi perilaku seseorang yang relatif permanen yang diperoleh. misalnya 
seseorang selalu menyapa salam pada saat bertemu dengan orang yang dikenalnya. Perilaku tersebut merupakan hasil belajar yang diperoleh dari lingkungan di mana ia dibesarkan. Berdasarkan teori interaksi simbolis, asal teori ini yang memusatkan pada kajian tentang bagaimana individu menginterpertasikan dan memaknakan interaksiinteraksi sosialnya. Ditekankan bagaimana peran aktif seseorang dalam sosialisasi, menurut Herbert Mead (1934) terdapat tiga proses tahapan pengembangan diri yang memungkinkan seorang pelajar menjadi mampu berpartisipasi penuh dalam kehidupan sosial yaitu preparatory stage, play stage, dan game stage.

Pada tahap pertama, belum mampu memandang perilakunya sendiri, hanya meniru perilaku orang lain yang ada disekitarnya dan mencoba memberikan makna. Tahap ke dua, mulai belajar seperti orang lain, berperilaku seperti contoh yang diberikan dari orang tuanya, melalui peran yang bermacam-macam itu mereka mempelajari perilaku individu lainnya, tahap ke tiga merupakan tahapan di mana anak melatih keterampilan sosialnya. Dia belajar bagaimana memenuhi harapan orang lain yang jumlahnya tidak hanya satu. Memenuhi harapan teman-temannya, kelompok bermainnnya, dan kelompok belajarnya. Inti pandangan pendekatan ini adalah individu, individu merupakan hal yang paling penting dalam konsep sosiologi. Individu merupakan obyek yang bisa secara langsung ditelaah dan dianalisis melalui interaksinya dengan individu yang lain.

Interaksionisme simbolik pada hakikatnya merupakan sebuah persfektif yang bersifat sosial-psikologis yang terutama relevan untuk penyelidikan sosiologis. Teori ini akan berurusan dengan struktur-struktur sosial, bentuk-bentuk kongkrit dari 
perilaku individual atau sifat-sifat batin yang bersifat dugaan, Interaksionisme Simbolik memfokuskan diri pada hakekat interaksi, pada pola-pola dinamis dari tindakan sosial dan hubungan sosial. Interaksi sendiri dianggap sebagai unit analisis, sementara sikap-sikap diletakkan menjadi latar belakang. Di sisi ini masyarakat tersusun dari individu yang berinteraksi yang tidak hanya bereaksi, namun juga menangkap, menginterpretasi, bertindak, dan mencipta. Individu bukanlah sekolompok sifat, akan tetapi merupakan seorang aktor yang dinamis dan berubah yang selalu berada dalam proses menjadi dan tak pernah selesai terbentuk sepenuhnya.

Masyarakat tidaklah bercirikan sesuatu yang statis yang selalu mempengaruhi dan membentuk diri kita, namun pada hakikatnya merupakan sebuah proses interaksi yang memiliki pikiran atau mind (akal budi) orang berperilku melibatkan pikiran dan metal, juga diri atau self, seseorang melalukan atau bertindak dengan proses sadar. Serta adanya society (masyarakat) yang merupakan pola-pola akal budi dan diri mampu berkembang dalam masyarakat melalui interaksi. Muncul pula melalui proses pengalaman dan aktivitas sosial selain itu keseluruhan proses interaksi tersebut bersifat simbolik di mana makna-makna dibentuk oleh akal manusia. Makna-makna itu kita bagi bersama yang lain, defenisi tentang dunia sosial dan persepsi kita mengenai, dan respon kita terhadap, realitas muncul dalam proses interaksi. Herbert Blummer sebagaimana di kutip oleh Abraham (1982) hal yang utama interaksionisme simbolik menyatakan: istilah interaksi simbolik" tentu saja merujuk pada sifat khusus dan khas dari interaksi yang berlangsung antar manusia. kekhususan itu terutama 
dalam fakta bahwa manusia menginterpertasikan atau mendefenisikan tindakan satu sama lain dari tidak semata-mata bereaksi atau tindakan satu sama lain.

Olehnya itu interaksi dimediasi oleh penggunaan simbol-simbol, diinterpertasi oleh penetapan makna dari tindakan orang lain. Mediasi ini ekuivalen dengan pelibatan proses inerpretasi antara stimulus dan respon dalam kasus perilaku manusia. pendekatan intekasionisme simbolik memberikan banyak penekanan pada individu yang aktif dan kreatif ketimbang pendekatan-pendekatan teoritis lainnya. Pendekatan interaksionisme simbolik berkembang dari sebuah perhatian ke arah dengan bahasa, namun Mead mengembangkan hal itu dalam arah yang berbeda dan cukup unik. Pendekatan interaksionisme simbolik menganggap bahwa segala sesuatu tersebut adalah virtual (maya).Interaksi antar individu manusia melibatkan suatu pertukaran simbol. Ketika kita berinteraksi dengan yang lainnya, interaksionisme simbolik mengarahkan perhatian kita pada interaksi antar individu, dan bagaimana hal ini bisa digunakan untuk mengerti apa yang orang lain katakan dan lakukan kepada kita sebagai individu. Dengan mengetahui interaksionisme simbolik sebagai teori. Maka kita akan memahami fenomena sosial lebih luas melalui pencermatan individu. Ada tiga hal yang penting dalam teori ini yaitu manusia bertindak berdasarkan maknamakna, makna tersebut didapatkan dari interaksi dengan orang lain, yang didapatkan pada saat interaksi berlangsung.

Interaksionisme simbolik memiliki beberapa gagasan yaitu mengenai konsep diri dikatakan bahwa manusia bukanlah satu-satunya yang bergerak di bawah. Pengaruh perangsang entah dari luar atau dalam melainkan dari organisme yang sadar 
akan dirinya. Kemudian gagasan konsep perbuatan di mana perbuatan manusia dibentuk dalam dan melalui proses interaksi dengan dirinya sendiri. Dan perbuatan ini sama sekali berlainan dengan perbuatan-perbuatan lain yang bukan makhluk manusia, kemudian konsep obyek di mana manusia diniscayakan hidup di tengahtengah obyek yang ada, yakni manusia-manusia lainnya.

Selanjutnya konsep interaksi sosial di mana proses pengambilan peran sangatlah penting. Yang terakhir adalah konsep aksi bersama atau joint action di mana di sini aksi kolektif yang lahir atas perbuatan-perbuatan masing-masing individu yang disesuaikan satu sama lain. Hanya sedikit ahli yang menilai bahwa ada yang salah dalam dasar pemikiran yang pertama "arti” (mean) dianggap sudah semestinya begitu, sehingga tersisih dan dianggap tidak penting "arti" dianggap sebagai sebuah interaksi netral antara faktor-faktor yang bertanggung jawab pada tingkah laku manusia. Sedangkan "tingkah laku” adalah hasil dari beberapa faktor. Kita bisa melihatnya dalam ilmu psikologi sosial saat ini. Posisi teori interaksionisme simbolik adalah sebaliknya bahwa arti yang dimiliki benda-benda untuk manusia adalah berpusat dalam kebenaran manusia itu sendiri. Disini kita bisa membedakan teori interaksionisme simbolik dengan teori yang lainnya, bahwa teori interaksionisme simbolik memandang bahwa "arti" muncul dari proses interaksi sosial yang telah dilakukan arti dari sebuah benda untuk seseorang tumbuh dari caracara di mana orang lain bersikap terhadap orang tersebut. Sehingga interaksi simbolik memandang "arti" sebagai produk sosial, sebagai kreasi-kreasi terbentuk melalui aktivitas yang terdefenisi dari individu saat mereka berinteraksi. 
Interaksi merupakan hubungan-hubungan sosial yang menyangkut hubungan antara individu, individu dengan kelompok, dan kelompok dengan kelompok. Tanpa adanya interaksi sosial maka tidak akan mungkin ada kehidupan bersama. Proses sosial adalah interaksi atau hubungan timbal balik atau saling mempengaruhi atau manusia yang berlangsung sepanjang hidupnya di dalam masyarakat.

Proses sosial adalah sebagai cara-cara berhubungan yang dapat dilihat jika individu dan kelompok sosial saling bertemu serta menentukan sistem bentuk hubungan sosial. Syarat terjadinya interaksi sosial terdiri atas kontak sosial dan komunikasi sosial. Kontak sosial tidak hanya dengan bersentuhan fisik. Perkembangan teknologi manusia dapat berhubungan tanpa bersentuhan, misalnya melalui aplikasi media-media yang ada di dalam smartphone. Komunikasi dapat diartikan jika seseorang dapat memberi arti pada perilaku orang lain atau perasaanperasaan yang ingin disampaikan oleh orang tersebut.

Proses interaksi sosial yang terjadi dalam masyarakat bersumber dari faktor:

1. Imitasi merupakan merupakan suatu tindakan sosial seseorang untuk meniru sikap, tindakan atau tingkah laku dan penampilan fisik seseorang.

2. Sugesti merupakan rangsangan, pengaruh, stimulus yang diberikan seseorang kepada orang lain sehingga ia melaksanakan apa yang disugestikan tanpa berfikir rasional.

3. Simpati merupakan suatu sikap seseorang yang merasa tertarik kepada orang lain karena penampilan, kebijaksanaan atau pola pikirannya sesuai dengan nilai-nilai yang dianut oleh orang yang menaruh simpati. 
4. Identifikasi merupakan keinginan sama atau identik bahkan serupa dengan orang yang ditiru (idolanya).

5. Empati merupakan proses ikut serta merasakan sesuatu yang dialami oleh orang lain. Proses empati biasanya ikut serta merasakan penderitaan orang lain.

Dalam kaitanya dengan dampak penggunaan smartphone terhadap perilaku sosial pelajar, akibat dari semua itu karena ada sifat meniru baik kehidupan dari dunia maya maupun mereka mendapatkan dari lingungan dalam hal ini adalah temantemannya. Ada ransangan yang terjadi atau pengaruh media-media hiburan dalam smartphone. Sehingga menjadikan sebuah ketergantungan pada pelajar, merasa tertarik dengan gaya hidup yang mudah di dapatkan melalui internet. Bahkan mereka ikut merasakan apa yang dialami para artis pemain film hiburan. Penggunaan smartphone, memiliki simbol-simbol yang menjadi sebuah penanda masyarakat menggunakan dengan berlandaskan kebutuhan serta menjadikan gaya hidup.

Kelebihan teori interaksionisme simbolik merupakan suatu teori yang berusaha mengungkap realitas perilaku manusia. Interaksi yang memunculkan makna khusus dan menimbulkan interpretasi atau penafsiran. Bagaimana interpretasi atau penafsiran, bagaimana suatu hal menjadi persfektif bersama. Bagaimana suatu tindakan memberi makna-makna khusus yang hanya dipahami oleh orang-orang yang melakukan. Seperti premis interaksionisme simbolik yaitu manusia bertindak terhadap suatu berdasarkan makna yang ada pada sesuatu itu bagi dirinya. Makna tersebut berasal dari interaksi sosial dengan orang lain, makna tersebut 
disempurnakan disaat proses interaksi sedang berlangsung. Artinya mind, self dan society saling memiliki hubungan yang erat.

\section{Teori Kritis Sosial}

Pemikiran Jean Baudrillard yang dikaitkan dengan postmodernisme dan pada strukturalisme. Teori Baudrillard adalah memperdebatkan makna dengan realitas yang dimasukkan dalam fiksi sains, karena fikirnnya yang cenderung tidak empiric dan sangat futuristik melihat realitas kontemporer lalu mereflesikan masa depan dengan membesar-besarkan atau bahkan memberi peringatan dini mengenai apa yang akan terjadi di masa depan jika kecenderungan kontemporer hari ini terus berlanjut.

Pada pemikiran awal, Baudrillad sangat dipengaruhi oleh Marxisme, namun terdapat perbedaan analisis kultural, dalam aliran Marxis. Analisis didasarkan oleh faktor produksi yang menurut Baudrillard adalah pemikiran Marxis yang tardisional. Dalam analisis Baudrillard yang didasarkan pada faktor konsumsi. Penguatan konsumsi dianggap sejalan dengan penguatan dari control produksi itu sendiri dan konsumsi dianggap sebagai suatu yang diorganisir oleh tatanan produksi sebagai perluasan kekuatan produksi. Serta merupakan kekuatan produktif yang penting bagi kaum kapital itu sendiri. Menurut Baudrillad fungsi-fungsi utama objek-objek konsumen bukanlah pada kegunaan atau manfaatnya melainkan pada fungsi nilai tanda atau nilai simbol yang disebarluaskan melalui iklan-iklan gaya hidup berbagai media. 
Pengaruh strukturalisme dalam analisis Baudrillard terlihat dalam analisisnya tentang proses pembentukan kode signifikansi, menurutnya objek konsumi dan sistem komunikasi (periklanan) adalah suatu proses pembentukan kode signifikansi dalam masyarakat yang konsumtif. Dalam melihat objek, Baudrillard bembangun sebuah logika pemikiran tentang konsumsi sebuah barang yaitu empat logika objek. Logika ini mengembangkan empat nilai dalam sebuah komoditas konsumsi dalam pemikirannya tentang sistem objek. Logika 4 objek yaitu

a. Nilai fungsional, yaitu tentang tujuan instrumental dalam hal ini penggunaan sebuah objek (dalam bahasa Max adalah “nilai guna” objek atau komoditas)

b. Nilai tukar adalah nilai ekonomis dari sebuah objek konsumsi

c. Nilai tukar simbolis, yaitu nilai yang telah dibangun bersama dalam masyarakat untuk sebuah objek konsumsi dibandingkan dengan objek lain.

d. Pertukaran nilai tanda objek merupakan pertukaran dalam perbandingan dengan objek-objek lain dalam suatu sistem objek.

Masyarakat konsumen yang berkembang saat ini adalah masyarakat yang menjalankan logika soal konsumsi dimana kegunaan dan pelayanan bukanlah motif terakhir dari tindakan konsumsi. Melainkan lebih kepada produksi dan manipulasi penanda-penanda sosial. Individu menerima identitas mereka dalam hubungannya dengan orang lain. Bukan dari siapa dan apa yang dilakukannya, namun dari tanda dan makna yang mereka konsumsi. Memiliki dan tampilkan dalam interaksi sosial. Dalam masyarakat konsumer, tanda adalah cerminan aktualisasi diri individu paling 
meyakinkan. Era kejayaan nilai tanda dan nilai simbol yang ditopang oleh meledaknya makna serta citra oleh perkembangan teknologi dan media massa.

Menurut Jean Baudrillard (George Ritzer (2013: 1) mengatakan bahwa media massa telah mendorong dan mengeneralisasi proses simulasi dari pada realitas orang diperlakukan sebagai simulasi yang melibatkan rekombinasi konstan dari berbagai tanda, elemen-elemen kode. Artinya bahwa dengan adanya media massa sangat berpengaruh dalam penggunaan alat komunikasi dalam hal ini smartphone. Mereka dengan mudah melihat simulasi-simulasi dari iklan-iklan yang terkait dengan smartphone dengan meningkatkan gaya hidup semata-mata tanpa mengetahui fungsi dan manfaat yang sebenarnya.

Baudrillard melukiskan kehidupan sebagai ditandai oleh simulasi (produsen atau alat komunikasi menciptakan penampilan yang lebih spektakuler agar lebih menarik konsumen). Proses simulasi yang mengarah kepada penciptaan simulacra yakni reproduksi atau peristiwa dengan kaburnya perbedaan antara tanda dan realitas, maka kita semakin sulit mengenali barang yang asli dan tiruan, sebagai contoh berbicaar tentang TV ke dalam kehidupan dan larutnya kehidupan ke dalam TV, akhirnya simulasilah yang menggambarkan sesuatu yang nyata, yang menjadi utama, kita telah menjadi sebuah budak simulasi yang membuat lingkaran yang tidak berujung pangkal.

Baudrillard pun melukiskan kehidupan hiper-realitas, misalnya media berhenti menjadi cerminan realitas melainkan justru menjadi realitas sendiri atau bahkan menjadi lebih nyata dari realitas itu sendiri. Keadaan hipper realitas membuat 
masyarakat modern menjadi berlebihan dalam mengonsumsi suatu yang tidak jelas esensinya. Kebanyakan dari masyarakat ini mengonsumsi bukan karena kebutuhan ekonominya melainkan karena pengaruh model-model dari simulasi yang menyebabkan gaya hidup mayarakat menjadi berbeda.

Baudrillard memusatkan perhatiannya pada kultur, yang dilihatnya mengalami revolusi besar-besaran dan merupakan bencana yang besar. Revolusi kultur menyebabkan massa menjadi semakin pasif ketimbang semakin memberontak seperti yang diharapkan oleh pemikir Marxis. Massa dilihat sebagai lubang hitam yang menyerap semua makna, informasi, komunikasi, pesan. Hal ini membuat mereka menjadi tidak bermakna, mereka menemukan jalannya sendiri, tak mengindahkan upaya yang bertujuan memanipulasi mereka. Ketidakacuhan, apatis, kelesuhan adalah istilah yang tepat unutk melukiskan kejenuhan massa tentang media, simulasi, dan hiper-realitas.

Salah satu unsur masyarakat postmodern terdapat adanya sejenis teknologi baru yang berkaitan dengan masyarakat. Sebagai pengganti teknologi produktif menjadi reproduktif yang dominan, khsusunya media elektronik dan komputer, seperti yang kita ketahui segala sesuatu aktifitas yang ingin kita lakukan tidak dapat dipisahkan oleh teknologi sehingga mengakibatkan ketergantungan atau kecanduan sehingga teknologi seperti ini menciptakan imej yang datar di dalam perilaku sosial masyarakat terkhsus pada pelajar.

Masyarakat tidak hidup dalam dunia yang berkecukupan tapi dalam masyarakat pertumbuhan. Yang namanya idelogi pertumbuhan selalu menghasilkan 
dua hal, kemakmuran dan kemiskinan. Makmur bagi yang diuntungkan dan miskin bagi terpinggirkan. Kenyatannya pertumbuhan adalah alat untuk membatasi ruang gerak orang-orang miskin. Karena itulah idelogi ini sengaja dilanggarkan untuk menjaga sistem. Pertumbuhan adalah fungsi kemiskinan, kata Baudrillard, pertentangan yang ada di dalamnya mengarah kepada kemiskinan psikologi dan kefakiran sistematis karena kebutuhan akan selalu melampaui produksi barang.

Permasalannya terletak pada hubungan sosial atau dalam logika sosial (masyarakat bukan hanya mengonsumsi barang, namun juga jasa manusia dan hubungan antar manusia). Ini tidak dapat dipecahkan oleh pebingkatan produksi, dengan inovasi kekuatan produksi, atau dengan apa yang biasanya kita pandang sebagai peningkatan daya beli. Satu satunya solusi untuk mengatasi masalah ini terketak pada perubahan dalam hubungan sosial dan dalam logika sosial. Kita memerlukan suatu logika sosial yang membawa bersamanya dengan banyak pertukaran simbolik, bukan nilai tukar.

\section{E. Penelitian Relevan}

Penelitian yang terdahulu oleh Muhammad Dahlan (2011), dengan judul Teknologi Komunikasi dan Perubahan Nilai Sosial (Studi Kasus Penggunaan Hadphone pada remaja di BTN Hartaco Indah Kota Makssar). Hasil dari penelitiannya menunjukkan bahwa (1) terjadainya perubahan atau pergeseran sosial nilai dari aspek kebiasaan, dan tata kelakuan danadat istiadat pada diri remaja terkait dnegan pemanfaatan teknologi komunikasi handphone dalam berinteraksi dengan 
lingkungannya (2) kemudahan dan kelancaran komunikasi adalah salah satu dampak positif sedangkan negatifnya kemudahan mengangses situs porno.

Penelitian oleh Fazrian Noor (2013) dengan judul Analisa Penggunaan smartphone Dalam Pertemanan di Sekolah Kelas X di SMA Negeri 4 Palangkaraya, hasil dari penelitiannya menunjukkan bahwa terdapat beberapa dampak posisif, negatif dan dampak netral dari penggunaan smartphone.

Penelitian oleh Dijey Pratiwi Barakati (2013) dengan judul Dampak Penggunaan smartphone Dalam Pembelajaran Bahasa Inggris (Persepsi Mahasiswa) hasil dari penelitiannya menunjukkan bahwa smartphone memliki dampak portabilitas, dampak kolaborasi, dan dampak motivasi.

Dari ke 3 penelitian di atas, menunjukkan bahwa memiliki persamaan yakni meneliti tentang penggunaan teknologi smartphone. Akan tetapi terlihat perbedaan bahwa penelitian sebelumnya lebih banyak menunjukkan tentang dampak-dampak yang ditimbulkannya, belum menunjukkan faktor yang melatar belakangi para pelajar menggunakan smartphone. serta belum menunjukkan makna dari pengunanan smartphone kekinian bagi para pelajar dan belum menenjukkan dampak terkhusus bagi perilaku pelajar baik dalam ruang lingkup akademik maupun nonakademik. Kemudian peneliti sebelumnya meneliti pada kalangan remaja yang diluar dari wilayah formal sedangkan peneliti lebih kepada satu fokus wilayah formal yaitu di SMA Negeri 3 Makassar. 


\section{F. Kerangka Konsep}

Adanya kebijakan sekolah SMA Negeri 3 Makassar yang membolehkan pelajar menggunakan teknologi telah menjadikan sebuah alat untuk digunakan sesuai dengan kebutuhan Sekolah. Pelajar menggunakan dengan mudah serta mampu memperolehnya, terutama bagi pelajar yang berlatarbelakang keluarga ekonomi menengah ke atas. Smartphone alat yang digunakan sebagai teknologi yang canggih mampu memudahkan bagi para pelajar dalam kegiatan proses belajar mengajar. Mampu meningkatkan minat belajar dan prestasi karena ruang belajar tidak hanya pada satu tempat sehingga melancarkan untuk tetap terhubung dengan jaringan kapan dan dimana saja. Pelajar pula dimudahkan dalam berinteraksi dan berkomunikasi dengan orang lain. Memudahkan mendapatkan sumber-sumber pelajaran melalui smartphone.

Penggunaan smartphone pada kalangan pelajar, tidak terlepas dari beberapa faktor yang melatar belakanginya yakni: (1) faktor pribadi, menunjukkan bahwa adanya dorongan dari pribadi pelajar dalam keputusan untuk menggunakannya, (2) faktor psikologi, dalam hal ini adanya persepsi, motivasi, sikap, gaya hidup yang berbeda-beda sehingga mempengaruhi pelajar untuk menggunakan smartphone. (3) faktor sosial, terdapat didalamnya budaya, kelompok rujukan seperti teman, keluarga, serta adanya status sosial yang mampu pula mendorong pelajar menggunakan smartphone. 
Dalam penggunaan teknologi smartphone ini menunjukkan perubahan Perilaku sosial yang merupakan sebuah tindakan, perbuatan, aksi seseorang sepanjang memiliki arti bagi dirinya sendiri maupun tindakan orang lain, artinya bahwa perbuatan pelajar dalam penggunaan smartphone digunakan karena memiliki manfaat dan dampak bagi dirinya sendiri serta orang lain. Perilaku yang terjadi terlihat bahwa adanya (1) perilaku peran seperti adanya sifat mandiri dan tergantung, (2) perilaku dalam hubungan sosial, seperti dapat diterima atau ditolak orang lain, suka bergaul (3) kecenderungan perilaku agresif, seperti sifat pamer atau menonjolkan diri dan sifat suka bersaing.

Selain itu penggunaan smartphone ini juga memeberikan dampak baik dilihat dari dampak (1) positif seperti memudahkan pelajar mengerjakan tugasnya, meningkatkan popularitasnya, mengubah pola aktivitas pelajar dan (2) dampak negatifnya seperti mengakibatkan pelajar menjadi ketergantungan, terkhusus pula berdampak pada perilaku. 


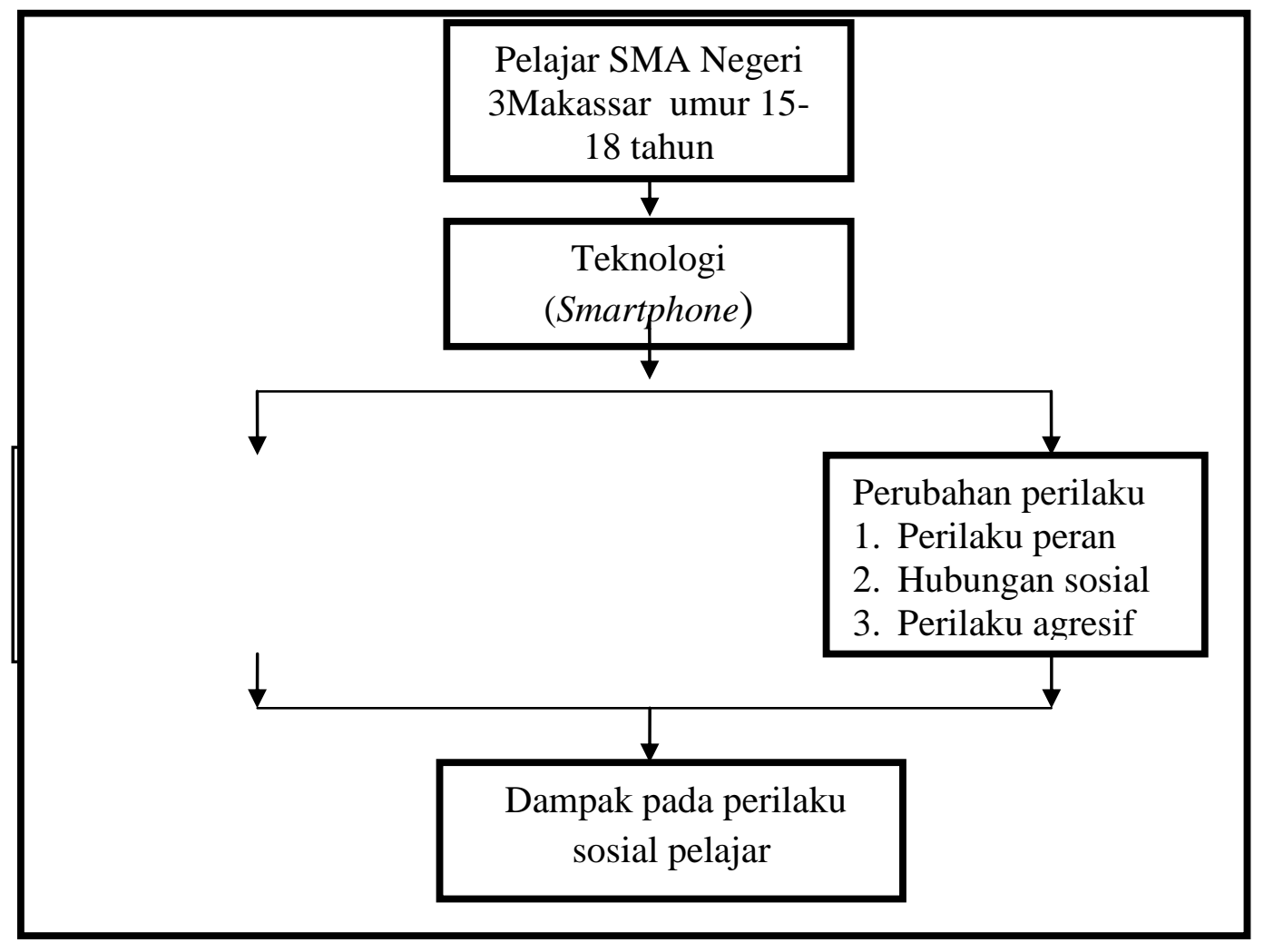

Gambar 2.2. Skema Kerangka Konsep 


\section{BAB III}

\section{METODE PENELITIAN}

Metode merupakan cara yang digunakan untuk memahami sebuah objek sebagai bahan ilmu yang bersangkutan, Nasir (1988: 51). Sedangkan penelitian adalah proses pengumpulan informasi dengan tujuan meningkatkan, memodifikasi atau mengembangkan sebuah penyelidikan atau kelompok penyelidikan. Namun pada dasarnya penelitian yakni setiap proses yang menghasilkan ilmu pengetahuan.

Penelitian digunakan untuk mengetahui dampak terhadap perilaku sosial pelajar yang aktif menggunakan smartphone. Dilakukan secara sistematis, terkontrol, empiris dan kritis agar hasil penelitian sesuai yang diinginkan dan tidak terlepas dari metode penelitian.

\section{A. Jenis dan Lokasi penelitian}

Berdasarkan permasalahan dalam penelitian ini, jenis penelitian yang digunakan adalah kualitatif. Menurut Satori dan Komaria (2010: 22), Penelitian kualitatif menekankan pada kejadian atau fenomena, gejala sosial yang ingin diungkap maknanya.

Jenis penelitian kualitatif ini digunakan untuk memberikan sumbangan terhadap teori, praktis, kebijakan, masalah sosial dan tindakan. Serta yang bertujuan memahami realitas sosial yang melihat objek penelitian dari apa adanya, bukan dari yang seharusnya. Metode kualitatif digunakan karena peneliti bermaksud 
memperoleh gambaran tentang Teknologi dan Perilaku sosial pelajar (Studi tentang dampak penggunaan Smartphone di SMA negeri 3 makassar).

Penelitian yang ini bertempat di SMA Negeri 3 Makassar jl. Baji areng No. 18. Merupakan salah satu sekolah yang ada di kota Makassar dengan $90 \%$ pelajar menggunakan smartphone. Selain itu terbukanya berbagai ruang pelajar dalam pemanfaatan untuk mendapatkan sumber belajar serta untuk tujuan tertentu. Jarak tempuh lokasi penelitian kurang lebih sekitar 20 menit. Penelitian ini dilaksanakan pada tanggal 09 februari-30 april 2016.

\section{B. Informan, dan Sumber Data Penelitian}

Informan dalam penelitian ini adalah Pelajar di SMA Negeri 3 Makassar yang rentan usianya 15-18 tahun. Dari beberapa teknik yang digunakan untuk menentukan informan dalam penelitian kualitatif. Teknik yang dipilih adalah purposive sampling. Artinya informan penelitian dipilih secara sengaja, sifat-sifat, kriteria atau karakteristik (1) berdasarkan umur 15-18 tahun. (2) kelas, yakni kelas X sebanyak 9 pelajar, kelas XI sebanyak 6 pelajar, dan XII sebanyak 5 pelajar, (3) jenis kelamin, perempuan sebanyak 8 pelajar dan laki-laki sebanyak 12 pelajar, serta aktif menggunakan smartphone, dengan pertimbangan penelitian dapat didekati. Informan yang dipilih dianggap mampu memberikan data atau informasi tentang apa yang akan dicapai dalam penelitian ini. Informan penelitian ini adalah berjumlah 20 pelajar.

Jenis data yang diperoleh berupa data kualitatif, meliputi ucapan dan perbuatan yang ditunjukkan informan penelitian. Berdasarkan hal tersebut, maka 
sumber data yang digunakan terdiri dari dua jenis, yaitu (1) Sumber data primer, adalah informasi lisan dari pelajar pemilik dan pengguna smartphone. (2) Data sekunder, adalah informasi pustaka yang digunakan sebagai konsep teoritis.

\section{Fokus Penelitian dan Deskripsi Fokus Penelitian}

\section{Fokus penelitian}

Berdasarkan judul yang akan diteliti yakni teknologi dan perilaku sosial pelajar (studi tentang dampak penggunaan Smartphone di SMA Negeri 3 Makassar). Hal difokuskan dalam penelitian adalah faktor yang melatar belakangi penggunaan smartphone, gambaran perubahan perilaku dalam penggunaan smartphone dan dampak dalam penggunaan smartphone di SMA Negeri 3 Makassar.

\section{Deskripsi Fokus Penelitian}

Agar tidak terjadi perbedaan intepretasi terhadap apa yang menjadi fokus dalam penelitian ini, maka fokus penelitian dianggap perlu untuk dideskirpsikan sebagai berikut:

a. Pelajar adalah seseorang yang mengikuti proses belajar mengajar yang berada dilingkungan pendidikan formal yaitu sekolah, di mana rentang umur 15 -18 tahun.

b. Perilaku sosial yaitu tindakan, perbuatan atau aksi seseorang yang berpengaruh terhadap dirinya sendiri maupun terhadap orang lain. 
c. Dampak adalah efek yang ditimbulkan penggunaan smartphone terhadap perilaku sosial pelajar. yang bersumber dari informan itu sendiri, Guru, Staff, Wakil Kepala Sekolah dan Kepala Sekolah.

d. Teknologi adalah sebuah alat atau benda yang digunakan oleh informan untuk mencapai tujuannya. Dalam hal ini teknologi informasi dan komunikasi smartphone (telpon genggam yang fasilitas dan fitur-fiturnya lebih canggih dari pada telpon genggam biasa).

\section{Instrumen Penelitian}

Istilah instrument penelitian ini adalah peniliti itu sendiri, sebagai pelaku utama dalam penelitian (human instrumen). Oleh karena itu. Isntrumen utama dalam penelitian ini adalah peniliti sendiri (Satori dan Komariah, 2010: 89). Peneiliti sebagai instrumen perlu didukung seperangkat alat bantu untuk kelancaran pengumpulan data di lapangan. Macam alat bantu terdiri dari yang paling sederhana sempai yang kompleks. Tetapi untuk mempermudah proses penelitian, peneliti menggunakan (1) format observasi lapangan (2) format panduan wawancara (3) kamera digital untuk kepentingan pengambilan gambar, serta smarphone untuk merekam percakapan.

\section{E. Teknik Pengumpulan Data}

Beberapa teknik dan teknis pengumpulan data selama penelitian terlaksana dapat diuraikan sebagai berikut: 


\section{Teknik Observasi}

Observasi yang digunakan dalam penelitian ini adalah observasi nonpartisipan, sehingga peneliti hanya melakukan serangkaian pengamatan terhadap fokus penelitian yang telah ditetapkan melalui format observasi yang telah dibuat sebelumnya. Adapun teknis pelaksanaan observasi lapangan antara lain:

a. Tanggal 10 Februari 2016 melakukan pengamatan di sekitar SMA Negeri 3 Makassar, pada saat itu diberikan arahan oleh Guru BK, yang sering masuk laporan tentang penyalagunaan smartphone, ada 6 pelajar, sambil mewawancarai mengenai kepribadian mereka.

b. Tanggal 11Februari 2016 pukul 10.30 melakukan kembali pengamatan di SMA Negeri 3 Makassar, pada saat itu diberikan izin untuk masuk beberapa kelas, dan menemukan dan menjumpai pelajar yang menggunakan smartphone, pada saat jam istirahat berlangsung terdapat 5 pelajar dengan berbagai hal dilakukan dalam penggunaan smartphone.

c. Tanggal 11 februari 2016, pukul 10.30, mengamati sejumlah pelajar yang sedang menggunakan smartphone, beberapa pelajar menggunakan di taman sekolah dengan berfoto-foto, yang meminjam milik temannya. Ada duduk di depan kelas sambil tunduk melihat smartphonenya, beberpa pelajar yang berkumpul melihat teman yang sedang asik menggunakannya, namun ada pula yang fokus hanya membaca buku dan mengerjakan tugas yang diberikan oleh guru. Seluruhnya terdapat 9 pelajar. 
Observasi ini merupakan kegiatan yang meliputi pencatatan kejadian kejadian, perilaku. Objek-objek yang dilihat dan hal-hal yang diperlukan dalam mendukung penelitian yang sedang dilakukan. Pada tahap awal observasi dilakukan secara umum, peneliti mengumpulkan data atau informasi sebanyak mungkin. Tahap selanjutnya melakukan observasi yang terfokus, yaitu mulai mengumpulkan data atau informasi yang diperlukan sehingga dapat menemukan pola perilaku dan hubungan yang terus menerus terjadi.

\section{Teknik Wawancara}

Wawancara yang digunakan adalah wawancara tidak terstruktur. Wawancara pada dasarnya dimaksudkan untuk memperoleh sejumlah informasi lisan dari subjek/forman penelitian. Sehingga sebagai data yang akan dinterpretasikan peneliti dalam mengungkapkan fokus permasalahan yang diajukan. Oleh karena itu, wawancara dilakukan dengan teknis sebagai berikut:

a. Tanggal 10 Februari 2016. Menjumpai pelajar siswa SMA yang telah menjadi sasaran informan, yang awalnya telah berkenalan dan saling tukar nomor telpon. Dan kemudian mewawancarainya berkaitan dengan penelitian.

b. Tanggal 15 februari 2016, kembali melakukan wawancara menghampiri pelajar sebagai informan, membangun dan menjalin komunikasi dengan para informan yang tengah yang sedang berkomunikasi lewat media sosial dari perangkat smartphonenya. 
c. Tanggal 17 februari 2016 menghampiri pelajar, serta kembali mewancarainya dan demikian hari-hari berikutnya.

\section{Teknik Dokumentasi}

Dokumentasi sebagai salah satu teknik yang digunakan dalam rangkaian kegiatan penelitian untuk menunjang data penelitian sebagai sumber data sekunder. Digunakan sejak awal penyusunan rencana penelitian, proses, dan akhir penelitian. Oleh karena itu, dokumentasi yang dimaksud terdiri dari:

a. Mengumpulkan sejumlah buku, artikel, makalah, dan laporan penelitian sebagai sumber bacaan/ rujukan, digunakan sebagai acuan konsep kajian fokus masalah penelitian.

b. Melakukan pengambilan gambar saat peneliti bersama subjek/ infoman penelitian menggunakan camera canon.

c. Mencatat hasil wawancara dengan para informan, dan mencatatnya kembali sebagai rekaman catatan kegiatan.

\section{F.Teknik Analisis Data}

Teknis analisis data yang digunakan adalah analisis deskriptif, yaitu suatu upaya untuk mendeskripsikan secara menyuluruh fokus kajian penelitian melalui interpretasi peneliti (Satori dan Komariah, 2010: 64). Analisis data merupakan serangkaian langkah untuk mengurai data menjadi bagian-bagian (Kategori dan subkategori) dari sumber data primer dan sekunder sebagai hasil penelitian. 
Analisis data yang digunakan secara berulang sampai peniliti memperoleh data yang akurat. Dapat dilakukan melalui tiga tahap, yaitu (1) reduksi data (2) penyajian dan pengelolaan data dan (3) tahap penarikan kesimpulan (Sugiyono, 2009: 98) tiga tahap tersebut secara integrative untuk menentukan hasil akhir analisis. Selanjutnya dapat diuraikan sebagai berikut:

1. Reduksi data

Data yang diperoleh dari sejumlah sumber diseleksi dilakukan atau difokuskan, penyederhanaan dan abstraksi. Langkah-langkah yang dilakukan adalah:

a. Informasi wawancara yang diperoleh dari sejumlah informan tentang, teknologi dan perilaku sosial pelajar studi tentang dampak penggunaan smartphone dalam bentuk catatan diskripsi hasil wawancara.

b. Data yang telah dicatat dan ditabulasi diseleksi sehingga yang diambil hanya yang dianggap paling representative untuk disajikan sebagai data.

2. Penyajian dan pengolahan data

Data dan informasi yang dikumpulkan, disajikan secara naratif. Sehingga permasalahan dapat dideskripsikan secara konprehensif/ menyeluruh. Langkah yang dilakukan adalah :

a. Data yang telah diseleksi diiterpretasikan dan direlevansikan dengan data etik.

b. Informasi yang diperoleh dari wawancara diinterpretasikan untuk memberikan gambaran teknologi dan perilaku sosial pelajar studi tentang dampak penggunaan smartphone. 
3. Penarikan kesimpulan

Penarikan kesimpulan diikuti dengan verifikasi internal, yaitu yang telah disajikan dan diolah dinterpretasikan kembali oleh peneliti. Mengingat penarikan kesimpulan yang dilakukan masih bersifat sementara, maka diperlukan verifikasi sehingga data yang disajikan lebih akurat. Langkah yang dilakukan adalah:

a. Mendeskripsikan fokus masalah yang sudah diinterpretasikan dan dilakukan penarikan kesimpulan.

b. Kesimpulan sementara direlevansikan dengan hasil observasi lapangan, sehingga diperoleh pemahaman masalah yang sesuai dengan kajian teoritis

c. Melakukan penyimpulan akhir dan mendeskripsikannya sebagai hasil penelitian.

\section{G. Teknik Pengabsahan Data}

Menurut Satori dan Komariah (2010: 164) penelitian kualitatif dapat dinyatakan sah apabila memiliki tingkat kepercayaan (credibility), keteralihan (transferability), kebergantunan (dependability), dan kepastian (compirmability). Berdasarkan keempat syarat tersebut, uji keabsahan data dalam penelitian selanjutnya dapat dijelaskan sebagai berikut :

1. Validasi internal (credibility), yaitu ukuran kebenaran data yang dikumpulkan, yang menggambarkan kecocokan konsep peneliti dengan hasil penelitian. Oleh karena itu, penelitian melakukan : 
a. Perpanjangan pengamatan (prolonged engagement), Perpanjangan keikutsertaan ini berarti peneliti kembali ke lapangan, melakukan pengecekan data dengan nara sumber yang pernah ditemui atau yang baru. Dengan perpanjangan ini berarti hubungan peneliti dengan narasumber akan semakin terbuka, saling mempercayai sehingga tidak ada informasi yang di sembunyikan lagi.

b. Meningkatkan ketekunan (persistent observation) yaitu melakukan pengamatan secara berulang dan kesinambungan pada berbagai objek lokasi penelitian.

c. Triangulasi (peer debriefing) sumber dan metode, yaitu menganalisis dan mencocokkan hasil interpretasi data hasil observasi dan wawancara, catatan lapangan, dengan pendekatan, teknik atau metode yang digunakan.

2. Validasi eksternal (keteralihan/transferability), pembuktian hasil penelitian apakah bisa digeneralisasikan pada setting social yang berbeda tetapi mempunyai karakteristik yang sama.

3. Kebergantungan (defendability/reabilitas), dimana hasil penelitian merupakan refrentasi dari rangkain kegiatan pencarian data yang dapat ditelusuri jejaknya. Oleh karena itu, audit komisi bimbingan atas proses penelitian, mulai dari penentuan masalah, memasuki lapangan, menentukan sumber data, serta penarikan keismpulan merupakan ukuran relibilitas proses penelitian.

4. Kepastian/objektivitas (compirmability) dilakukan bersamaan dengan defendibility, untuk menguji keterkaitan hasil dan proses penelitian. 


\section{BAB IV}

\section{HASIL PENELITIAN DAN PEMBAHASAN}

\section{A. Gambaran Lokasi dan Subjek Penelitian}

\section{Deskripsi Lokasi Penelitian}

SMA Negeri 3 Makassar yang berlokasikan di jl. Baji Areng No. 18 merupakan salah satu sekolah menengah atas Negeri yang ada di Makassar, provinsi Sulawesi-Selatan. Sama dengan SMA pada umumnya di Indonesia yang ditempuh dalam waktu tiga tahun pelajaran mulai dari kelas X smpai kelas XII.

\section{Deskripsi Pelajar SMA Negeri 3 Makassar}

SMA Negeri 3 Makassar memiliki program atau jurusan Ilmu Pendidikan Alam (IPA) dan Ilmu Pendidikan Sosial (IPS), rentang kelas X, XI IPA, XI IPS, XII IPA, dan XII IPS. Berbagai pula fasilitas dimiliki SMA Negeri 3 Makassar untuk menunjung kegiatan belajar mengajar. Fasilitas tersebut yakni kelas, perpustakaan, laboratorium biologi, laboratorium fisika, laboratorium kimia, laboratorium komputer, dan laboratorium bahasa. Di sekolah ini pun memiliki ekstrakurikuler seperti palang merah remajah (PMR), pasukan pengibar bendera (PASKIBRA 03), jendela Informasi (JENIUS 03), organisasi pramuka (BAJIARENG 03), support team basket (CHEERSLEADER 03), AMBALAN, SOFTBALL SMAGA, TRIPLE, dan ikatan remaja Mushollah (IKRAMAL). 
Pelajar di SMA Negeri 3 Makassar dengan mudah memilih jururan serta ekstrekurikuler yang mereka minati. Ada pun jumlah siswa SMA Negeri 3 Makassar berdasarkan data yang diambil berjumlah 993 orang yang ditinjau dari jenis kelamin tanpa membedakan umur dapat dilihat pada tabel berikut:

Tabel 4.1 Jumlah Pelajar Keseluruhan di SMA Negeri 3 Makassar

\begin{tabular}{|c|c|c|c|c|}
\hline No & Kelas & Laki-laki & Perempuan & jumlah \\
\hline 1 & X & 190 & 205 & 395 \\
\hline 2 & XI & 155 & 168 & 323 \\
\hline 3 & XII & 116 & 159 & 275 \\
\hline \multicolumn{2}{r|}{ Jumlah keseluruhan } & 461 & 532 & 993 \\
\hline
\end{tabular}

Sumber: Data Sekunder, Februari 2016

Berdasarkan dari tabel di atas, menunjukkan bahwa siswa SMA Negeri 3 Makassar dengan jumlah siswa 993, kelas sepuluh (X) berjumlah 395, laki laki sejumlah 190 pelajar dan perempuan 205. Kelas sebelas (XI) berjumlah 323 pelajar dengan laki-laki sejumlah 155 dan perempuan 168 pelajar, serta kelas duabelas (XII) berjumlah 275 dengan laki-laki sejumlah 116 dan perempuan 159, dengan demikian total pelajar laki laki yaitu 461 dan perempuan 532, jika dijumlahkan pelajar keseluruhan tanpa dilihat jenis kelaminnya adalah 993 pelajar.

\section{Kurikulum dan Visi Misi Sekolah}

Kurikulum yang digunakan di SMA Negeri 3 Makassar adalah Kurikulum Tingkat Satuan Pendidikan (KTSP). Disusun, dikembangkan dilaksanakan dengan 
memperhatikan standar kompotensi dan kompotensi dasar yang dikembangkan Badan Standar Nasional Pendidikan (BSNP), dengan melihat kondisi satuan pendidikan, potensi dan karakterstik daerah, serta sosial budaya masyarakat setempat, peserta didik, dan komite. Dan bertujuan untuk mewujudkan sekolah yang efektif, produktif, dan berprestasi.

Keterlaksanaan kurikulum tingkat satuan pendidikan ini memberikan otonomi kepala sekolah dan satuan pendidikan untuk mengembangkan kurikulum sesuai dengan potensi, tuntutan dan kebutuhan masing-masing. Pada sistem KTSP sekolah memiliki hak penuh dan resonsibility dalam menetapkan kurikulum dan pembelajaran sesuai dengan visi, misi sekolah. Namun mempertanggung jawabkan kepada masyarakat dan pemerintah.

Dalam pengguaan smartphone di sekolah menjadi sebuah kebebasan yang diberikan oleh kepala sekolah. Menggunakan berdasarkan kebutuhan sekolah dalam proses belajar guna untuk meningkatkan produktifitas dan efektifitas dalam pembelajaran serta susiai dengan misi sekolah yakni menguasai dasar-dasar pengetahuan dan teknologi.

Visi sekolah yakni menghasilkan lulusan yan memiliki iman dan taqwa, mengauasai dasar-dasar ilmu pengetahuan dan teknologi serta mempunyai pola pikir inovatif, kreatif dan konpetitif dalam era persaingan global.

Misi sekolah (1) mengoptimalkan pengelolaan kegiatan pembelajaran yang komprehensif dan integratif dengan tolak ukur peningkatan mutu siswa. (2) peningkatan disiplin, tanggung jawab, dedikasi dan peduli masyarakat sekolah 
terhadap penyelenggaraan pendidikan di sekolah. (3) mengembangkan dan menigkatkan kinerja setiap personil sekolah agar dapat bekerja sama dan saling mendukung sebagai suatu sistem untuk mencapai tujuan sekolah. (4) menggalang kesadaran masyarakat khususnya orang tua siswa untuk terlibat dan berfikir mengenai peningkatan mutu pendidikan di sekolah. (5) mengembangkan potensi siswa dengan keanekaragaman kultural, sosial ekonomi, bakat, minat, dan kemampuan melalui jalur pembinaan kesiswaan. (6) memperdayakan semua sarana dan prasarana dalam pelaksanaan proses belajar mengajar di sekolah. (7) meningkatkan pengelolaan sistem adminstrasi sekolah dan informasi sekolah secara sistematik pada seluruh komponen sekolah.

\section{Deskripsi Informan Penelitian}

Informan dalam penelitian ini sebanyak 20 pelajar yang dipilih secara purposive. Dalam hal ini berdasarkan pada ktriteria atau karakteristik tertentu yang dianggap mempunyai sangkut paut. Diketahui sebelumnya dan terlibat langsung dalam suatu komunikasi dan perubahan aspek nilai sosial kaitannya dengan penggunaan smartphone di SMA Negeri 3 Makassar.

Oleh sebab itu, sebelum memasuki permasalahan yang telah dirumuskan. Maka akan dikemukakan profil informan itu sendiri sebagai dimensi-dimensi yang telah diterapkan dalam penelitian ini yaitu mencakup tingkat umur, kelas, jenis kelamin. 
a. Umur

Umur memberikan suatu gambaran tentang kemampuan dan kedewasaan seseorang dalam mempersiapkan suatu hal, maka umur informan sangat penting untuk diketahui dan dapat dikaitkan dengan pengetahuan, pengalaman seseorang dalam merespon sesuatu serta membentuk pola perilaku. Untuk lebih jelasnya dapat di lihat dari tabel berikut:

Tabel 4.2. Kelompok Umur Informan

\begin{tabular}{|l|c|c|}
\hline No & Kelompok umur & Jumlah pelajar \\
\hline 1 & $15-16$ tahun & 12 pelajar \\
\hline 2 & $17-18$ tahun & 8 pelajar \\
\hline
\end{tabular}

Sumber: Data Primer, Februari 2016

Berdasarkan tabel 4.2. Sesuai dengan karakteristik informan rentan usia 15 tahun sampai 16 tahun dengan jumlah 12 sedangkan rentan umur 17 sampai 18 tahun dengan jumlah 8 pelajar.

b. Kelas

Kelas dalam arti sempit yaitu ruangan yang dibatasi oleh empat dinding tempat sejumlah pelajar berkumpul untuk mengikuti proses belajar mengajar, ruangan dalam arti luas adalah suatu masyarakat kecil yang merupakan bagian dari masyakarat sekolah yang sebagai kesatuan diorganisir menjadi unit kerja secara 
dinamis menyelenggarakan berbagai kegiatan belajar-belajar yang kreatif untuk mencapai suatu tujuan. Para pelajar di SMA Negeri 3 Makassar, mampu melakukan kegiatan dalam masing-masing kelas, yang terbagi beberapa tingkatan kelas yaitu kelas sepuluh (X), kelas sebelas (XI), dan kelas (XII).

Tabel 4.3. Tingkat Kelas Informan

\begin{tabular}{|l|c|c|}
\hline No & Tingkat Kelas & Jumlah Informan \\
\hline 1 & Kelas X & 9 pelajar \\
\hline 2 & Kelas XII & 6 pelajar \\
\hline 3 & Kelas XII & 5 pelajar \\
\hline
\end{tabular}

Sumber: Data Primer, Februari 2016

Berdasarkan Tabel 4.3. Jumlah informan diambil sesuai dengan tingkat kelasnya yakni Kelas X sebanyak 9 pelajar, kelas XI sebanyak 6 pelajar, sedangkan kelas XII sebanyak 5 pelajar.

c. Jenis Kelamin

Jenis kelamin informan terbagi menjadi dua yakni jenis kelamin perempuan dan jenis kelamin laki-laki. Berikut tabel perbedaan jumlah informan dilihat dari jenis kelaminnya. 
Tabel 4. 4. Jenis Kelamin Informan

\begin{tabular}{|l|c|c|}
\hline No & Jenis Kelamin & Jumlah Informan \\
\hline 1 & Perempuan & 8 pelajar \\
\hline 2 & Laki-laki & 12 Pelajar \\
\hline
\end{tabular}

Sumber: Data Sekunder, Februari 2016

Berdasarkan Tabel 4.4. diatas, menunjukkan bahwa jenis kelamin perempuan sebanyak 8 pelajar, sedangkan jenis kelamin laki-laki sebanyak 12 pelajar.

\section{B. Deskripsi Hasil Penelitian}

\section{Faktor yang Mendorong Penggunaan Samartphone Pelajar SMA Negeri 3 Makasar.}

a. Faktor Pribadi

Faktor pribadi adalah hal-hal unik pada seseorang, banyak faktor pribadi yang mempengaruhi penggunaan smartphone. Faktor-faktor demografis berupa karakteristik-karagteristik individual seperti usia, jender, tingkat pendidikan, pekerjaan dan pendapatan. Sesuai dengan hasil wawancara yang dikemukakan oleh: A. Muh. Danu Tirta, 15 tahun menyatakan bahwa:

"Saya menggunakan smartphone karena senang, bisaka donwload apa saja, dan keinginankuji sendiri, saya menggunakan smartphone OPPO karena bangus di pake dan bagus aplikasinya" (wawancara 10, februari 2016). 
Pernyataan di atas dipertegas oleh temannya, Naufal Akbar, 16 tahun, mengatakan bahwa:

"dibiarkanma menggunakan karena sudah SMA ma oleh orangtuaku karna di sekolah kan di suruhjaki juga, saya juga pake smartphone Sony karena kemauankuji sendiri terus skarang jarangmi orang pakai hp biasa, sekarang orang pakaimi PIN BBM jadi tidak repotmaki beli pulsa tinggal kuota mami dan mudahmaki juga internetan". (wawancara 10 februari 2016)

Wawancara di atas, ketika itu menanyakan pada saat jam istirahat berlangsung, tepatnya di depan kelas, hal ini menunjukkan bahwa penggunaan smartphone dipengaruhi oleh faktor pribadi yaitu A. MDT memuaskan keinginannya sendiri untuk menggunakan merek apa saja yang dia inginkan. Bersama dengan NA. Menunjukkan pula bahwa dia menggunakan karena ada pula keingian atau seleranya sendiri memilih smartphone yang dianggap bahwa lebih baik dibandingkan dengan smartphone yang lainnya. Selain itu diberikannya kesempatan oleh orangtuanya karena melihat usia yang sudah layak menggunakan. Sehingga dinyatakan bahwa faktor pribadi mendorong pelajar dalam penggunan smartphone.

b. Faktor Psikologi

Faktor psikologi menjadi pula pertimbangan untuk membeli sebuah produk khusunya smartphone yang mereka inginkan. Berikut hasil wawancara yang dikemukakan oleh: Dita Maharani, umur 17 tahun

“ awalnya pergika di MTC dengan temanku, mauka beli smartphone merk advan, tapi pada saat itu ada SPG menawarkan smartphone blackberry yang lagi promo, na badndingkanki spesifikasi dan fitur-fiturnya, sehingga kubandingkan ada memang perbedaanya akhirnya belima blackberry" (wawancara 12 februari 2016) 
seperti halnya yang dikemukakan oleh temannya Muh. Riadi Arief, 17 tahun, bahwa:

"kan ini kebutuhan, bisaki donload, bisaki main games, kalau ada tugas bisaki dengan mudah dan tidak repot lagi cari di buku, terus motivasiku menggunakan karena memudahkan selain bisaki pakai menelpon bisaki juga pakai sebagai hiburan". (wawancara 12 Februari 2016).

Ketika itu DM selesai berolahraga basket ball dan mendekatinya untuk melakukan pengamatan dan melakukan wawancara. Berdasarkan hal tersebut menunjukkan bahwa faktor psikologi mempengaruhi keputusan pelajar menggunakan sebuah smartphone. Adanya promosi-promosi yang ditawarkan oleh SPG yang memiliki keterampilan mempengaruhi sehingga DM termotivasi dan berubah fikiran dalam membeli smartphone. Sama halnya yang dirasakan MRA teman akrabnya pun terdorong untuk memenuhi satu kebutuhannya serta bergantung pada sikap mereka terhadap pembelian smartphone yang ingin dimilikinya. Selain itu hal ini dikarenakan di SMA Negeri 3 Makassar memiliki misi dapat menguasai teknologi untuk aktif, kreatif dan inovatif.

Gaya hidup pun menjadi sebuah faktor psikologi yang dominan untuk menggunakan smartphone, ada adopsi yang mempengaruhi keinginan minat dan opini terhadap pembelian.

Informan atas nama, Nur Ainun 16 tahun yang menyatakan bahwa:

"Saya menggunakan smartphone merk Samsung, karena zamannyami, apa yang lagi ngetrend itu yang saya beli dan teman-teman juga banyakmi yang pakai, jujur saya lebih senang berinteraksi lewat media sosial karena tidak kelihatanji mukatta jadi leluasa bercanda sama teman-teman kalau tidak digunakan dalam sehari terasa lan-lain (wawancara 15 februari 2016). 
Temannya atas nama Dita Maharani 17 tahun, menyatakan bahwa:

"kalau saya pakai smartphone balckberry dan Iphone awalnya mau beli karena penasaran, saya pakai untuk media sosial dan main games kalau waktu senggang, kalau tidak dipakai dalam sehari seperti ada yang kurang lengkap karena sudah jadi bagianki dari hidupku (wawancara 15 februari 2016).

Berdasarkan pengamatan, menunjukkan kepemilikan smartphone pada NA timbul karena untuk memenuhi gaya hidupnya. Menurutnya lagi populer, walaupun pada saat itu mereka tidak terlalu membutuhkannya. Tapi untuk memenuhi tuntutan kemajuan teknologi dan seiring berjalannya waktu penggunaan produk tersebut menjadi bagian yang tak terpisahkan dari aktivitas mereka. Kehidupan seseorang telah masuk pada dunia yang serba pilihan, dapat memilih hidup dalam kelompok masyarakat yang diinginkannya. Bahkan boleh hidup dalam dunia yang serba global. Smartphone hadir sebagai jawaban atas pemenuhan gaya hidup mereka. Dengan memanfaatkannya untuk mengakses media sosial yang tersedia didalamnya, menurutnya cukup aktif jika ditanyakan mengenai sosialisasi yang di lakukan di dunia maya. Menurutnya pula lebih muda mendapatkan teman atau kenalan di berbagai daerah di Indonesia.

Rasa penasaran pun mejadi bagian dari faktor psikologi, dengan tempat yang sama, pernyataan DM yang menggunakan smartphone ketika banyangnya waktu luang serta menjawab rasa penasarannya. Adanya teknologi baru yang diberkembang dalam masyarakat diikuti penggunaannya yang dilakukan oleh orang disekitarnya. Terutama pada kepentingan komunikasi terutama di media sosial. Pelajar pun menggunakan lebih dari satu jenis samrtphone diantaranya digunakan lebih sering. 
Hal ini merupakan di luar dari kebutuhannya sehingga dinyatakan bahwa faktor psikologi pun menjadi faktor pendorong dalam penggunaannya.

c. Faktor Sosial

Pada era berkembangnya zaman, masyarakat lebih dominan beralih ke smartphone karena kegunaannya mampu melakukan tugas di luar dari tugas normalnya dari dikarenakan memiliki fungsi hampir sama dengan laptop atau komputer dan faktor sosial pun menjadi sebuah faktor dalam penggunaan smartphone.

Informan sebelumnya menunjukkan bahwa terdorong adanya pribadi dan psikologi, lain halnya dengan informan atas nama Anisya Namira Syahrial, 17 tahun, mengatakan bahwa:

"kan kebutuhan di sekolah itu, dipakai cari materi-materi, teruskan ada fitur qipper school yang digunakan dan ada guru yang memang suruhki untuk donloadki jadi pakaima juga karena tidak adaji larangan toh, jadi kenapa tidak dipakai terus kan adaji uangnya orang tua (wawancara 21 Maret 2016)

Jika dilihat dari pernyatan diatas, sama halnya dengan temannya Ichsan Rifky Ramadhan:

“Orangtua kan pegawaiji semua, jadi bisaja na belikan smartphone Iphone, terus tidak marahji juga kalau mauka beli yang mahal soalnya na bilngji kebutuhan juga di sekolah, demi kelancaran, dari pada belika yang murah sebentar-sebntar rusakmi lagi, mending yang mahal tapi berkualitaski". (wawancara 21 Maret 2016)

Di selah-selah jam istirahatnya menjumpai ANS dan IRR yang satu kelas, berdasarkan pengamatan bahwa ada keyakinan atau ada kesepakatan bersama baik 
dari pihak Kepala sekolah dan guru. Dibiarkan menggunakan smartphone dalam ruang lingkup sekolah bahkan dalam proses belajar mengajar jika diizinkan ketika dibutuhkan. Dan terdapat fitur qipper school memudahkan para guru dan pelajar untuk membuat soal dan mengerjakan soal tanpa bertatap muka. Bahkan dimana saja selama terkoneksi internet. Selain itu status sosial orang tua mereka sangat menjadi sebuah alasan untuk membeli sebuah produk.

Hal ini pun dipertegas oleh Guru atas nama Dra. Samsudduha, umur 52 tahun, menyatakan bahwa:

"Memang disekolah ini dibiarkan menggunakan smartphone, dengan alasan smartphone itu membantu dalam pembelajaran, kemudian ada pembelajaran qipper school, di mana bisa memberikan tugas dan langsung mengerjakannya, apa lagi kalau gurus edang sibuk misalnya".

Berdasarkan pengamatan dan wawancara yang dilakukan, selain adanya kemampuan orang tua yang mampu membelikan smartphone apa saja yang dibutuhkan oleh anaknya (pelajar). Hal ini pula diberikannya hak bagi sekolah untuk menggunakan demi kelancaran sebuah proses pembelajaran.

\section{Gambaran Perubahan Perilaku Sosial Pelajar yang Menggunakan}

\section{Smartphone}

Perubahan perilaku pelajar dalam penggunaan smartphone di sekolah, menunjukkan berbagai macam perilaku yang ditemukan berdasarkan wawancara dan pengamatan langsung. Untuk itu akan dijabarkan beberapa alasan pelajar dan berdasarkan pengamatan. 
a. Kecenderungan Perilaku Peran

Perubahan perilaku pelajar terhadap penggunaan smartphone terlihat dalam penelitian ini, dan pelajar telah mengakui perasaan yang dirasakan ketika menggunakan dan tidak menggunakanya dengan berbagai alasan. Pelajar yang menjadi informan atas nama Hisbul jabbar, 15 tahun, bahwa:

“jujur ketika kita menggunakan smartphone biasa itu kalau ketagihanmaki, tidak rasa itu ada biasa teman yang panggilki tapi tidak dihiraukan, apa lagi kalau main game COC-maki susah sekali dirasa orang keluar karena seruh. Dulu waktu saya tidak menggunakan rajinka membaca buku sekarang selama kenalma tidak terlaluma suka buku, apa lagi kalau terbatasmi buku mending di internet ada semuaji”. (wawancara 22 Maret, 2016)

Kemudian temannya Danu Tirta mengatakan bahwa:

"kalau menggunakan smartphone itu merasa mandiriki dalam mengerjakan tugas-tugas di sekolah, bisaki cari sendiri tugas apa lagi kalau mau kerja matematika kan semua ada kalkulatornya itu smartphone jadi tidak perlumaki lagi pinjam-pinjam kalkulatornya teman, terus kalau mauki kasiki informasi teman tidak mestimaki pakai surat tapi tinggal di BBM ki, atau ditelpon pakai Video Call (VC)". (wawancara 25 Maret 2016).

Berdasarkan wawancara di atas, menunjukkan bahwa terdapat beberapa perilaku dalam penggunaan smartphone, HJ menjadikan sebagai barang yang menjadikan kepercayaan diri ketika menggunakan. Namun kesopanan menjadi terkisis, interaksi yang kurang baik ditunjukkan pada pengguna smartphone yang aktif. Perilaku HJ terlihat adanya ketagihan atau ketergantungan. Pada awalnya HJ merasakan tidak ada perubahan namun ketika kenal dengan smartphone dengan kecanggihannya mereka mulai menjadi pribadi yang kurang menjunjung tinggi kesopananya apa lagi dalam hal berinteraksi. 
Serta temannya yang lain DT dalam menggunakan smartphone itu merasakan kemandirian dalam mengerjakan tugas. Jika sebelumnya DT meminjam alat bantu, namun sesudah menggunakan smartphone DT dengan mudah mengerjakan tugas. Menggunakan calculator yang terdapat di dalam smartphone tersebut. Dan jika dulu mereka ingin menyampaikan informasi tidak perlu lagi memanggil atau menggunakan surat, tapi hanya sekedar menggunakan media sosial dalam samartphonenya. Beberapa menit mereka telah mengetahuinya.

\section{b. Perilaku Dalam Hubungan Sosial}

Pelajar dalam penggunaan smartphone mempengaruhi pula perilaku dalam hubungan sosial, hal ini diakui oleh, A. Danu Tirta bahwa:

"sebelum saya menggunakan smartphone kan handphone biasaji, jarangka bergaul, pendiam sekalinya menggunkanma samrtphone percaya diri sekalima, seringma bergaul dengan teman-teman tidak dibilangimaki kampungan, terus dimedia sosial bisama banyak teman jadi tidakmi kumerasa sendiri, dulunya bilangka apaji itu pamer-pamer foto sekalinya saya punya begituka juga" (wawancara 26 Maret, 2016)

Berdasarkan pengamatan di atas menunjukkan perubahan perilaku yang dirasakan ketika belum menggunakan dan sesudah menggunakan smartphone, disisi lain sangatlah menjadi sebuah kemudahan. Disisi lain pula mampu merubah kebiasaan lama, seperti terlalu tertarik untuk berfoto-foto namun sesudahnya A. MDT ini mengikuti teman yang sering menyebarkan foto-foto melalui media sosial. Pada awalnya merasa percaya dirinya kurang akan tetapi ketika menggunakannya ada percaya diri yang tinggi, serta A.MDT merasakan mudah bergaul. Lebih-lebih ketika 
mereka memiliki jenis samrtphone yang tidak jauh canggihnya dibandingkan dengan temannya yang lain.

c. Kecenderungan Perilaku Agresif

Terdapat beberapa perilaku agresif oleh pelajar sebelum dan sesudah menggunakan smartphone, berikut beberapa informan yang telah diwawancarai, atas nama Muh.Aqil, 16 tahun, bahwa:

“ saya pakai smartphone jujur karena ada temanku yang biasa natunjukkan itu smartphonenya, jadi jengkelka kurasa makanya kuganti smartphoneku yang lebih diatasanya, terus kalau paski donload biasa loading jadi kugantiki." (wawancara 28 Maret, 2016 )

disela-sela istirahatnya terlihat adanya perbedaan perilaku yang dirasakan dengan temannya duduk bersampingan yaitu Muh.Fikri, menyatakan bahwa

"saya pakai smartphone pas kelas 3 SMP sampai masuk SMA ini, tapi tidak terlalu sukaja ikuti perkembangannya soalnya dilarangka sama orang tua, terus saya liat teman-teman jarangmi belajar, banyakmi nakal karena pergaulan lewat smartphone. Saya suka itu olahraga apa lagi bola, baru saya tidak adaji pacarku jadi tidak adaji bisa di hubungi. Seandainya dilarangki pakai samrtphone di sekolah tidak pakainya juga, banyak teman yang salah menggunakan samrtphone tapi saya itupi disuruhka buka kemudian saya buka, itu juga pasti kalau diliatki buka yang lain-lain langsungki di kasi teguran jadi pasti jelek juga nilaita"(wawancara 11 April 2016).

Berdasarkan hasil wawancara, menunjukkan bahwa MA memiliki daya saing yang tinggi ketika menggunakan smartphone. Tidak ingin dikalahkan oleh orang lain, sehingga keinginan untuk memiliki atau menggantinya semakin tinggi pula. Perubahan perilaku ini muncul dikarenakan bukan sekedar melihat bahwa 
kegunaanya smartphone serta fungsinya akan tetapi keinginan, persaingan yang mengakibatkan perubahan itu terjadi. Namun ada pun masih menjunjung tinggi perilaku saling menghargai kepada sesama. Selain itu MF menunjukkan masih adanya perilaku yang masih kental dengan peraturan-peraturan yang berlaku di sekolah. Tanpa mengikuti gaya trend masa kini, walaupun perkembangan teknologi semakin besar baik di bidang pemasaran maupun penggunaannya. Dengan sadar tidak terlalu mengikuti hingga tdak berpengaruh oleh sikap atau perilakunya.

\section{d. Dampak Penggunaan Smartphone}

Dari hasil penelitian, menunjukaan bahwa informan sangat mengetahui dampak yang ditimbulkan oleh penggunaan smartphone. Mereka dapat merasakan langsung dampak baik bersifat positif maupun negatif. Untuk itu akan dijabarkan hasil wawancara mereka yang memberikan alasan bahwa dampak dari penggunaan smartphone terutama pada perilaku pelajar di SMA Negeri 3 Makassar.

a. Dampak Positif

Seperti yang dirasakan oleh Andi. Muh. Danu Tirta umur 15 tahun:

"kalau positifnya itu, bisa mendonwload kamus bahasa inggris jadi tidak perlu lagi membuka kamus atau membawa kamus berat-berat, bisa juga menggunakan media sosial untuk berkomunikasi biasa janjian dengan teman ikuti ekstrakurikuler di sekolah. memudahkan dalam segala hal (wawancara, 28 Maret, 2016)

Begitu pula menurut Hisbul Jabbar yang telah diwawancarai sebelmnya, umur 15 tahun, bahwa : 
" bisa komunikasi lama tanpa batas waktu bisa tengah malam kalau ada tugas diberikan sama guru, kalau handphone biasa kan ada batas waktunya kalau mendaftarki menelpon. Tidak merasa kampungan" (wawancara, 21 Februari 2016)

Dipertegas dengan temannya atas nama Muh. Riadi, 17 tahun, bahwa:

"dapat teman banyak, terus seperti ada video-video lucu bisaki postingki lewat youtube atau lewat Facebook, dan banyak yang suka, banyak yang liat bisaki kayak artis dadakan"(wawancara 21 Maret 2016)

Berdasarkan hal ini kembali mewawancarai pada saat jam istiraht berlangsung di depan kelasnya, hal ini menunjukkan bahwa ada kemudahan berkomunikasi yang dirasakan AMDT dan MA dalam penggunaan smartphone serta untuk memenuhi kebutuhan yang lain, memberikan kefesienan dalam mengerjakan sesuatu terutama untuk mendapatkan jawaban dari tugas-tugas yang diberikan, tanpa batas waktu, dimana pun dan kapan pun bisa melakukan apa saja dengan mudah.

Nampak pula bahwa ada peningkatan popularitas yang menjanjikan di rassakan oleh MR ketika menggunakan smartphone. Dengan alat ini bisa melakukan apa saja bahkan membuat para pengggunanya terlihat eksis di media sosial oleh bantaunnya.

Adapun kutipan wawancara dari informan guru yang ada di sekolah, yakni Ibu Ramdana,S.Pd., M. Pd. Umur 52 Mengatakan bahwa:

"Pelajar kami memberikan kebebasan dikarenakan itu salah satunya buku paket tidak teralu banyk, dan lembar kerja siswa kan tidak lagi perjual belikan sehingga smartphone ini bisa dijadikan alat untuk mendapatkan materi dan bisa juga mendapatkan jawaban dari tugasnya. Ada surat edaran dari Diknas yang melarang jual beli Buku sehingga menurut kami samrtphone ini 
membantu, memang ada beberapa sekolah yang melarang karena itu tergantung dari pihak dan kesepakatan dani masing-masing sekolah."(wawancara 21 Ferbruai 2016).

Wawancara di atas, menunjukkan bahwa selain memudahkan mampu pula menjadi sebuah hal yang meningkatkan produktivitas yang tidak lagi memerlukan biaya membeli buku atau LKS, hanya mengandalkan smartphonenya mereka bisa menpadatkan yang diinginkan.

b. Dampak Negatif

Fenomena smartphone di era globalisasi sangat menjadi sebuah dampak yang mendunia, salah satu dampak yang ditemukan berdasarkan wawancara dari informan atas nama Hisbul 15 tahun, bahwa:

"saya itu menggunakan karena merasa kayak ada yang aneh kalau tidak menggunakan, apa lagi kalau guru di dalm kelas tidak asik mengajar biasa bete di belakang pakaima smartphone ku, apa lagi kalau ada game yang disuka biasa mau sekaliki mainkanki, (wawancara 22 Maret 2016)

Lain halnya yang dikemukakan oleh Dra. Ariani. S.Pd, umur 52 tahun, bahwa:

"Saya liat itu anak-anak sekarang, tidak lagi melihat waktu untuk menggunakan, ada itu kalau biasa makan adami juga smrtphonenya di tangannya terus selang beberapa menit baru lagi makan, jadi tidak rasakanmi makannya, lebih ke smartphonenya ji. Biasa juga di panggil anak-anak tidak terlalu na dengar, ditegur tidak terlalu na hiraukan, apa lagi kalau sanksisanksi ringanji pasti besok atau lusa terulang lagi. Pernah ada kejadian, guru sedang menjelaskan di depan, ada beberapa pelajar dibelakang sedang asik mengganggu temannya, katanya ingin memperlihatkan video-video terlarang.

(wawancara 22 Maret 2016) 
Berdasarkan wawancara di atas, menunjukkan bahwa ada sifat kecanduan yang dimiliki oleh para pelajar dalam penggunaan smartphone. Aktivitas yang dilakukan secara berulang-ulang dapat menimbulkam dampak negatif. Ketergantungan yang diakibatkan cenderung mengulangi perilaku yang sama akan memberikan pengaruh buruk terhadap kehidupan sosial pelajar itu sendiri. Hilangnya kepercayaan guru sangat mempengaruhi nilainya. Ada pula faktor ketidak nyamanan, atau terjadi kesenjangan interaksi, kesenjangan interaksi dimaksud adalah interaksi langsung (fisik) antar pengguna smartphone dan bukan pengguna. Berikut informan yang telah diwawancarai, atas nama Nur Ainun, 16 tahun, bahwa:

"Saya banyak temanku yang belum kuakrapi karena jarangki bicara dan tidak ada Bbmannya bahkan lebih banyak ku akrabi kakak senior di kelas lain (wawancara 22 Maret 2016).

Wawancara dengan temannya yang lain atas nama, Fikri, 15 tahun, menyatakan bahwa:

"kalau saya iya punyaka teman cewek kalau di BBM akrab sekali sering Bbman, tapi biasa dibicarai di kantin atau kalau ketemuka kita kayak malumaluji tidak sama ternyata." (wawancara 28 februari 2016 )

Dari pernyataan informan di atas, terlihat bahwa terjadi kesenjangan yang terjadi antara pelajar yang pengguna dan bukan pengguna walaupun dalam satu kelas yang sama. Tapi bukan jadi alasan utama mereka menjalin komunikasi yang intensif. Hal yang dekat bisa menjadi jauh dan jauh bisa menjadi dekat. Artinya pelajar memiliki hubungan yang unik akibat kebiasaannya berinteraksi di media sosial walaupun pelajar berada di kelas yang sama, tapi belum tentu mereka saling berbicara 
atau membuat suatu hubungan yang akrab. Sebaliknya ada pelajar yang sangat akrab dalam hubungan sosialnya dengan pelajar kelas lain sebab mereka lebih sering berkomunikasi lewat media sosial. Hal ini bisa dijumpai oleh masyarakat luar dengan pelaku yang berbeda.

Tercipta hubungan palsu pun menjadi faktor ketidak nyamanan yang diakibatkan oleh teknologi khsusunya smartphone. Hal ini membuat pengguna smartphone (pelajar) semakin sering melakukan interaksi baik terhadap teman sekolah, teman sepermainan, anggota keluarga bahkan orang baru dikenalnya sekalipun.

Penggunaan tersebut memiliki dampak sosial yang berbeda, hubungan yang mereka jalin di media sosial bisa saja merupakan hubungan pertemanan yang akrab atau lebih dari itu. Tetapi jika dihadapkan pada kehidupan sosial yang sebenarnya. Mereka seolah-olah memiliki hubungan sosial yang biasa saja. Terdapat hubungan yang dikatakan oleh Jeand Baudrillard dalam wacana hipperalitas bahwa dalam masyarakat post-modern dengan adanya teknologi masyarakat dapat menciptakan dunia nyatanya sendiri. Wacananya mengenai simulasi merupakan model-model nyata yang tanpa asal usul realitas awal, melalui model simulasi manusia dijebak di dalam suatu ruang yang disadarinya sebagai nyata, meskipun sesungguhnya semu, maya, dan belaka. Dikemukakan kembali oleh NA bahwa:

"Saya banyak yang invetka di FB dan di BBM, saya suka ji kalau banyak teman, biarpun laki-laki, tapi kalau na ajakma keluar pergi ketemuan tidak mauma". (wawancara 21 Maret 2016) 
Informan ini cantik sehingga wajar ketika banyak yang ingin berkenalan dengannya, mengakui bahwa keakraban yang lahir di dunia maya belum tentu sama ketika mereka bertemu. Sehingga hubungan yang tercipta di media sosial seakan palsu dan sangat bertolak belakang dengan kehidupan sosial yang nyata. Berdasarkan hal itu simulasi merupakan suatu ruang pengetahuan yang dikonstruksikan oleh media informasi yang perbedaan antara nyata dan fantasi. Yang benar dan yang palsu, menjadi sangat tipis. Media informasi dan komunikasi mereka lebih nyata dari pengetahuannya. Namun antara media informasi dan pengetahuan sama membentuk sikap, dan perilaku yang berbeda di setiap manusia.

\section{Pembahasan}

Teknologi sebagai salah satu hal yang menjadi dasar perubahan sosial, dengan mudahnya menciptakan lingkungan kehidupan manusia yang baru. Teknologi menjanjikan sebuah kemajuan dalam masyarakat, ketercapaian tujuan masing-masing manusia, perubahan yang mampu dirasakan oleh siapa saja yang menggunakannya. Segala sesuatunya yang digunakan untuk sebuah kemajuan, kemudahan, peningkatan produktivitas, mampu menguasai alam semesta bahkan di luar angkasa berkat jasa teknologi.

Usia pelajar merupakan usia yang rentan akan terpengaruh dan mudah meniru hal-hal yang baru seperti mode yang biasanya dijadikan sebagai pola. Acuan bagi pelajar terutama mode baik berupa fisik maupun perilaku mode ini disebut pula 
dengan trend. Menurut Thedorson (Kahiruddin 2002: 27) bahwa perilaku adalah respon atau reaksi seseorang tidak hanya meliputi reaksi kegiatan jasmaniah, tetapi subjektif. Lebih luas digunakan adalah kebiasaan yang merupakan suatu masa yang terbesar yang dilaksanakan pada seseorang, perkataan, pikiran, atau perasaan. Pandangan tentang apa yang dianjurkan dan maksud serta bermanfaat terhadap seseorang.

Lahirnya sebuah produk smartphone atau ponsel cerdas yang mempunyai kemampuan dengan penggunaan dan fungsi yang menyerupai komputer. Perangkat telekomunikasi serbaguna dan menjadi telepon yang bekerja menggunakan seluruh perangkat lunak sistem operasi yang menyediakan hubungan standar yang mendasar bagi pengembangan aplikasi. Merupakan sebuah telepon yang menyajikan fitur-fitur canggih yang dapat dikatakan sebagai komputer kecil yang mempunyai kemampuan sebuah telepon. Smartphone merupakan pengembangan dari telepon seluler yang kemudian ditambahkan fitur dan fasilitas lainnya sehingga menjadi telepon yang cerdas bagi para kalangan mampu menggunakan dan memilikinya terkhusus oleh para pelajar.

Hasil penelitian yang didapatkan di lapangan menunjukkan para pelajar menggunakan dengan berbagai macam faktor-faktor yang sangat mempengaruhi. Mulai dari faktor pribadi, psikologis, dan faktor sosial. 


\section{Faktor yang Mendorong Pelajar SMA Negeri 3 Makassar}

Cerminan remaja terkhsusus para pelajar sebagai generasi penerus bangsa sesungguhnya merupakan cerminan bagaimana bangsa kita kedepannya. Kondisi pelajar yang berada di SMA Negeri 3 Makassar merupakan salah satu problema sosial yang hendaknya diperhatikan sedini mungkin. Sebab mereka adalah generasi penerus yang sebaiknya memiliki moral dan akhlak yang tinggi dan dapat memanfaatkan perkembangan teknologi dengan hal-hal yang baik tanpa mengurangi perilaku yang baik.

Tak seperti proses keputusan pembelian dalam pasar organisasi, yang dipengaruhi oleh personil pusat pembelian atau faktor lain (misalkan permintaan turunan dan kebijakan perusahaan), proses keputusan pembelian memang dipengaruhi oleh faktor pribadi, psikologi dan sosial (Monle Lee dan Carla Jhonson, 2004: 113). Kepemilikan dalam penggunaan smartphone terkhsus bagi para pelajar dilihat dari beberapa faktor.

Faktor pribadi seperti tingkat pendapatan dan pekerjaan, pelajar sangat dibantu, serta cenderung membuat pilihan berbeda menyangkut penggunaan smartphone. Adanya keinginan sendiri untuk memilikinya, tanpa adanya dorongan dari orang lain. Karakteristik seperti usia, para pelajar telah diberikan kesempatan untuk menggunakan dikarenakan sudah layak dan mereka telah banyak mengetahui tentang dunia luar. Tingkat pendidikan pelajar SMA yang rentan umurnya mulai dari 15 tahun ke atas memiliki rasa penasaran sangatlah tinggi, hingga berbagai macam kehidupan mereka hadapi. Smartphone menjadi alat kebutuhan bagi mereka, 
pekerjaan sebagai pelajar dapat memudahkan proses belajar mengajarnya. Serta tingkat pendapatan orang tua menjadi alasan dalam pembelian tanpa melihat murah atau mahalnya.

Faktor psikologi dalam penggunaan smartphone, para pelajar memiliki dorongan, persepsi, gaya hidup, dan motivasi yang berbeda-beda dalam sebuah informasi barang atau produk. Meskipun barang yang dipasarkan melalui media tidak dapat mengendalikan persepsi orang, hanya saja sering kali mencoba mempengaruhinya. Munculnya sebuah produk melalui iklan-iklan menjangkau konsumen di bawah ambang kesadaran yang telah memebesar-besarkan akibat frekuensi praktik -praktik tersebut.

Faktor sosial pun menjadi bagian dari hal yang mendorong penggunaan smartphone adanya keyakinan, nilai, dan simbol yang dibagi bersama oleh masyarakat dan diteruskan dari satu generasi ke generasi berikutnya membentuk sebuah budaya. Perbedaan-perbedaan nilai dalam berbagai budaya yang menjadikan para pelajar menggunakan smartphone. Adanya pula rujukan dari teman-teman, serta adanya status sosial keluarga sehingga mereka lebih mudah memndapatkan dan menggunakanya.

Menurut Baudrillard (Ritzer, 2014: 95) menyatakan "bahwa masyarakat konsumsi tidak lagi digerakkan oleh kebutuhan dan tuntutan konsumenn, melainkan oleh kapitalis roduksi yang sangat besar, rasionalitas konsumsi dalam sistem masyarakat konsumsi telah jauh berubah, karena saat ini masyarakat membeli barang bukan sebagai upaya untuk memenuhi kebutuhan, namun lebih sebagai pemenuhan hasrat, oleh karena itu proses konsumsi bukan hanya sekedar proses ekonomi melainkan melibatkan proses psikologi" 
Artinya selain adanya faktor ekonomi, sosial yang mampu menunjang pelajar mampu menggunakan smartphone. Akan tetapi lebih pula kepada dorongan dari psikologi yang objek hasrat yang muncul secara bawah sadar secara imajiner, dan mencari sebuah substansi dalam dunia objek simbol-simbol barang dikonsumsi. Masyarakat konsumsi akan membeli simbol-simbol yang melekat pada suatu objek, sehingga objek-objek konsumsi dalam masyarakat banyak yang terkikis nilai guna dan nilai tukarnya.

Era modern yang diidentikkan dengan masyarakat digital, setiap aktivitas manusia yang akan digerakkan dengan serangkaian teknologi. Hal inilah yang dikemukakan oleh Baudrillard (Nanang Martono 2014: 216) bahwa teknologi adalah sebuah kemajuan. Seseorang yang menggunakan teknologi akan tercerminkan bahwa sebuah kemajuan, selain itu menjadikan pula sebagai simbol status bagi pemakainnya yang dapat dipertontonkan kepada khalayak.

Smartphone awalnya memiliki daya guna dan manfaat sebagai penunjang dalam pembelajaran. Pelajar dengan mudah membuka internet dengan mencari sumber pembajaran seperti ada beberapa mata pelajaran yang sangat membutuhkan smartphone seperti mata pelajaran bahasa inggris. Dengan mudahnya membuka aplikasi kamus bahasa tanpa mengandalkan kamus manual yang begitu tebal, mata pelajaran matematika yang membutuhkan kalkulator, mata pelajaran sosiologi yang ketika menemukan istilah-istilah ilmiah bisa menemukan melalui internet di Geogle, begitu pun mata pelajaran yang lainnya. Samrtphone sangatlah membantu bagi para 
pelajar terkhusus di SMA Negeri 3 Makassar. Berbagai memanfaatan smartphone oleh pihak sekolah, tanpa menggunakan wifi sekolah, dengan smartphone para pelajar bisa mengakses dengan lancar.

Berdasarkan pengamatan dan wawancara beberapa guru mata pelajaran mengizinkan para pelajar menggunakan dikarenakan buku-buku paket terbatas sehingga salah satu cara untuk mengefesienkannya dengan membuka smartphone untuk memcari bahan ajar. Kemudian tidak diperkenankannya menjual lembar kerja siswa (LKS) sehingga para guru dengan mudah memberikan kesempatan kepada pelajar untuk membuka internet mencari jawaban-jawaban berkaitan dengan soal yang diberikan.

Proses belajar mengajar selain menggunakan sistem tatap muka dalam suatu ruangan. Bisa pula melalui media Elearning (elektronic learning) Proses pembelajaran dengan memanfaatkan teknologi yang bisa di donload melalui smartphone mereka. Sehingga guru dan para pelajar tidak harus bertatap muka, bisa dilakukan proses belajar mengajar dengan jarak jauh. Dalam hal ini dapat melalui media email, blog, teleconfrens, atau web resmi sekolah.

Smartphone ini sangat memberikan solusi mudah untuk kehidupan seharihari pelajar. Seperti untuk mencari alamat teman-temannya hanya perlu membuka geogle map. Dengan kecepatan internet dengan waktu yang singkat alamat pun diketahui, dengan inginnya berkomunikasi dengan melihat video atau gambar hanya membuka aplikasi BBM atau Line mereka lebih mudah untuk menggunakannya. Beberapa aplikasi games-games yang berpoint, jika mengumpulkan point, para 
pelajar bisa menukarkan berupa snack atau makan ringan di toko-toko yang mensponsori seperti AlfaMart. (pengakuan dari beberapa infroman).

Perilaku pembeli dapat dipengaruhi pula oleh sebuah kelompok rujukan, termasuk keluarga, teman, dan organisasi-organisasi profesional. Kelompok ini bisa terdiri dari satu atau lebih orang yang memberikan pengaruh langsung terhadap pengambilan keputusan pelajar.

Para pelajar mulai dibekali dengan pengetahuan dalam pengoprasikan dalam pemanfaatan teknologi terhusus smartphone. Agar nilai-nilai asing yang masuk melalui media tersebut dapat disaring, oleh sebab itu guru beserta staff tidak terlepas dari kontrol dan memberikan banyak aktifitas ekstrakurikuler untuk menunjang bakat mereka dari segala bidang keterampilanya sehingga tidak terlepas dari berbagai perestasi yang dimiliki oleh para pelajar.

\section{Gambaran Perubahan Perilaku Pelajar di SMA Negeri 3 Makassar}

Berkaitan dengan penggunaan smartphone, tidak terlepas oleh tangan-tangan para pengiklan. Menjadikan daya tarik untuk mengonsumsi produk-produk yang dipromosikannya. Sehingga kalangan manapun mampu untuk mengonsumsinya. Menurut Raymond Williams (Mike Featherstone 2008: 48) bahwa salah satu pemakaian terbaru dari istilah mengoonsumsi adalah merusak (to destroy), memakai (to use up), membuang-buang (to waste), menghabiskan (to exhaust) kepada khalayak. Sehingga mengakibatkan perubahan perilaku. 
Munculnya perubahan perilaku yang dilihat dari perilaku peran, para pelajar telah menunjukkan masing-masing tindakannya dalam penggunaan smartphone. Terutama sesudah menggunannya, seperti meningkatnya rasa kepercayaan diri yang tinggi bagi pelajar dalam melakukan proses interaksi, baik ke sesama teman atau pun para guru dan staff di sekolah. Namun terkikisnya sebuah kesopanan yang menjadi pula penilaian bagi guru-guru di sekolah.

Merasakan kemandirian sesudah menggunakan smartphone, guna mencari sebuah sumber belajar. Ketika sebelum menggunakannya pelajar merasa tergantung oleh teman-temannya yang lain, meminjam alat pembelajaran, hal ini tidak lagi dirasakan karena pelajar mampu mencari sendiri yang dibantu oleh smartphone. Perubahan perilaku dalam hubungan sosial pun dialami oleh pelajar yakni sesudah menggunakan pelajar dengan mudah untuk bergaul pada siapa pun. Tidak ada lagi batasan bagi mereka untuk berteman dengan siapa saja melalui media sosial. Sehingga terdapat tindakan yang diterima dan tidak diterima seperti adanya perilaku individual, pelajar dengan kurang bersosialisasi dengan teman-teman yang ada disekitarnya. Serta merubah perilaku yang dulunya tidak merasa eksis menjadi eksis yang tidak kalah dengan teman-temannya yang lain.

Kecenderungan perubahan perilaku yang agresif juga menjadi bagian dari gambaran perubahan perilaku pelajar. Dilihat dari adanya persaingan yang terjadi dalam memilih merek smartphone, serta adanya sifat pamer terhadap orang lain, namun ada pula pelajar yang tidak bersifat agresif. Masih menjunjung tinggi peraturan-peraturan baik orang tua, maupun di sekolah dan tidak terlalu mengikuti 
gaya yang populer di masa kini. Perubahan yang lain terdapat perilaku yaitu merubah kebiasaan lamanya menjadi kebiasaan baru yang disadarinya, hal ini pula tidak terlepas dari interaksi yang dilakukannya.

Teknologi menjadi salah satu bagian yang mampu mempengaruhi perubahan sosial, mempengaruhi perbedaan serta sistem sosial (Sztompka, 1994: 26) di mana didalamnya yang dimaksud adalah perubahan perilaku, hubungan sosial, lembaga, dan struktur sosial pada waktu tertentu.

Manusia tidaklah dianggap sebagai masyarakat yang berkeadaan tetap, tetapi sebagai proses, bukan sebagai objek yang semu yang kaku tetapi sebagai aliran peristiwa terus-menerus tanpa henti. Masyarakat yang ada di dalamnya melakukan tindakan, serta proses kehidupan yang berbeda yang senantiasa berubah dengan derajat kecepatan, intensitas yang berbeda.

Demikian halnya yang berkaitan dengan perubahan yang terjadi pada pelajar dalam penggunaan smartphone tersebut. Terdapat perubahan seiring berkembangnya kecanggihan-kecanggihan dalam fitur-fitur smartphone yang menjajikan kenyamanan dan kebahagian dalam menggunakannya. Sebelum dan sesudah menggunakan, pelajar merasakan ada perbedaan yang sangat signifikan terhadap perilakunya. Menguat dan melemahnya pendirian pelajar dikarenakan pula adanya keakraban, berkenalan sampai bersahabat mengakibatkan perubahan perilaku yang dialami.

Perubahan yang terjadi pada manusia tidak terlepas dari peran teknologi yang mempengaruhinya. Manusia yang tidak mampu hidup tanpa teknologi, teknologi 
dapat menyatukan dan dapat pula memisahkan masyarakat karena didalamnya terdapat manipulasi yang sangat tinggi bagi kerangka berfikir manusia, yang disebabkan kemampuan teknologi dalam mengubah dan mengelolah benda-benda alamiah menjadi sesuatu yang bersifat artifisal demi memenuhi kepentingannya (Nanang Martono, 2014: 206).

(Hensin, 2006: 56) menyatakan secara sosiologis, teknologi memiliki makna yang lebih mendalam dari pada peralatan. Teknologi menetapkan suatu kerangka bagi kebudayaan nonmateriil yang dimiliki suatu kelompok. Jika teknologi suatu kelompok mengalami perubahan, maka cara berfikir manusia juga akan mengalami perubahan. Hal ini juga berdampak pada cara mereka berhubungan dengan yang lain

Artinya bahwa tidak terlepas dari tangan-tangan manusia yang cerdas membuat teknologi. Dilihat dari barang itu sendiri maupun fitur atau aplikasi terdapat didalamnya yang dapat mengubah daya berfikir pelajar untuk menggunakannya. Baik dilihat secara kebutuhan maupun keinginan-keingiann yang berlebihan sehingga menimbulkan perubahan perilaku sesudah menggunakan teknologi (smartphone).

Berdasarkan teori dari Baudrillard (Ritzer, 2014: 95), yang mengatakan munculnya ide, persfektif masuk dalam kebutuhan manusia yang beralih menjadi sebuah keinginan yng hidonis atau berlebih-lebihan sehigga daya guna dan manfaat tidak terlihat lagi, sehingga menimbulkan pula perilaku pada pengguna.

Terlihat pengamatan pada pelajar yang awal mulanya penggunaan smartphone ini dikarenakan adanya kebutuhan dalam kesehariannya tekhusus penunjang dalam proses belajar mengajar di sekolah. Akan tetapi dengan kecanggihan-kecanggihan yang ada dialamnya menjadikan kesenangan dan kebebasan, menimbulkan perilaku kesopanan pelajar mulai terkisis. Walaupun tidak secara keseluruhan pelajar 
mengalaminya. Tidak menentunya waktu yang layak mengggunakan smartphone, sehingga nampaklah sebuah perubahan yang terjadi pada penggunaannya.

Berdasarkan pula teori dari Mead, yang menyatakan adanya perilaku seseorang terbentuk melalui simbol dengan perkembangan akal fikiran, kesadaran dan masyarakat. Menunjukkan bahwa pelajar dalam penggunaan smartphone tidak terlepas karena adanya fikiran-fikiran tersendiri, sadar dan tidak sadar dalam penggunaan. Serta ruang lingkup sekolah yang memberikan kebebasan menggunakan serta tempat saling bersosialisasi sehingga berpengaruh pada perilaku. Bentuk perubahan perilaku dapat dilihat dari berbagai bentuk jenis perilaku yang merupakan karakter masing-masing seseorang yang dapat diamati ketika seseorang berinteraksi dengan orang lain. hal tersebut dapat dilihat melalui sifat dan respon antar pribadi.

Perilaku atau tindakan menurut Weber, menggunakan kata perikelakuan untuk perbuatan-perbuatan yang bagi si pelaku mempunyai arti subjektif yang hendak mencapai suatu tujuan. Berakal dalam kesadaran individu, dan menurutnya perilaku sosial di bagi menjadi 4 bagian ditegaskan K.J. Veeger (1990): (1) Kelakuan di arahkan seara rasional, kepada tercapainya suatu tujuan, (2) Kelakuan sosial yang berorinetasi pada nilai, (3) Kelakuan yang menerima orientasi dari persaan atau emosi, atau orang yang melampiaskan nafsu, (4) Tindakan tradisional yan dimaknai sebagai tindakan yang tidak memperhitungkan pertimbangan rasional.

Beberapa pula konsep menurut Max Weber perilaku sosial yakni (1) Atensi, yaitu sikap seseorang yang ingin diperhatikan, (2) Kesadaran, yaitu suatu tindakan yang dilakukan secara sadar supaya dikatakan berpenampilan menarik atau tampak 
berbeda dengan penampilan yang lainnya, (3) Persepsi, yaitu suatu kesadaran ingin tampil mempersepsikan diri, kemauan mempersiapkan sesuatu.

Perilaku pelajar di sekolah menjadi bagian penting dalam penilaian guru-guru per mata pelajaran. Perilaku masuk dalam tiga aspek penilaian guru yakni afektif, kognitif dan psikomotorik. Ketika salah satu diantaranya kurang maka akan mempengaruhi nilai akhir dari mereka. Oleh sebab itu perilaku salah satu penunjuang penilaian guru dalam menentukan prestasinya. Tindakan atau perilaku pelajar tidaklah semata-mata hanya sekedar penilaian guru saja, akan tetapi menjadi sebuah modal kehidupan yang bermasyarakat untuk kedepannya, akan menjadikan ciri kekhasan bagi pribadi mereka masing-masing.

Melihat pelajar di SMA Negeri 3 Makassar dalam pemanfaatan samrtphone, tidak lagi hanya sebatas penggunaan untuk pembelajaran akan tetapi juga sebagai media hiburan yang menyebabkan perilaku pelajar semakin merosot. Untuk menyadarkan para pelajar tentu perlu ada kedisplinan yang tinggi dan menjunjung tinggi visi-misi sekolah dan tidak terlepas oleh lingkungan keluarga yang merupakan lembaga utama seharusnya menyadarkan dan memberikan pemahaman, agar para pelajar tersebut menggunakan samrtphone dengan bijak.

\section{Dampak Penggunaan Smartphone di SMA Negeri 3 Makassar}

Kemajuan teknologi meningkatkan perubahan yang begitu besar pada kehidupan. Melalui media massa para pengiklan pun turut untuk bekerja sama demi mengingklankan sebuah produk. Produk dibesar-besarkan dengan segala janji-janji 
kenikmatan namun berdampak pada pola kehidupan masyarakat terkhusus bagi para pelajar.

Dampak positif dalam penggunaan smartphone yaitu dimudahkannya mendapatkan sumber belajar, tidak lagi mendapatkan dengan susah cukup membeli kuota internet kemudian menggunakan sepuasnya. Memudahkan pula berkomunikasi melalu media sosial yang tersedia, meningkatkan pula popularitasnya pelajar yang menjadi sebuah wahana hiburan ketika memiliki waktu yang senggang.

penggunaan yang bersifat negatif, para pelajar menggunakan dengan waktu yang cukup lama menimbulkan radiasi dari smartphone tersebut. Walaupun memiliki pengaturan merendahkan dan meningkatkan cahaya dari smartphone, tetap saja terkadang merasakan radiasinya. Selain itu bahwa dari penelitian menunjukkan bahwa benar ada perilaku-perilaku kecandauan yang dirasakan oleh para pelajar. Dengan senangnya menggunakan terkadang lupa waktu dan kondisi yang layak untuk menggunakan. Banyaknya aplikasi yang membuat pelajar nyaman membuatnya selalu menggunakan.

Baudrillard mengatakan melalui iklan adalah sebuah kepanjangan tagan kapitalis yang mudah dikendalikan dan mudah mengendalikan pasar. Melalui iklan setiap produk dapat ditawarkan dengan berbagai cara yang cukup menggoda selera konsumen seolah-olah diombang-ambing dengan berbagai penawaran dalam iklan. Menawarkan kelbihan-kelebihan produk namun iklan tidak pernah bertanggung jawab atas segala resiko yang timbul dari iklan tersebut. Iklan pula menawarkan 
mitos, misalkan mitos kenikmatan, sehingga konsumen digiring untuk mengonsumsi produk agar tampil beda.

Periklanan adalah komunikasi komersial dan nonpersonal tentang sebuah organisasi dan produk-produknya yang ditransmisikan. Ke suatu khlayak target melalui media massa seperfi televisi, radio, koran, majalah, direct mail (pengeposan langsung), reklame luar ruang kendaraan umum dan internet. Periklanan memiliki berbagai macam tipu daya di dalamnya terdapat kepentingan bisnis, kebutuhan konsumen, kreativitas dan regulasi pemerintah berjumpa. Para pebisnis dalam periklanan saling bekerja sama dengan membangun sebuah perencanaan, pengganggaran, koordinasi. Membuat iklan serta para pengiklan bekerja sama untuk menginklankan sebuah barang maupun jaza dengan melalui teknologi yang efektif dan cepat dalam mempromosikannya. Pelajar menggunakan smartphone memang sesuai dengan tujuan-tujuan dan keinginannya sendiri namun berdampak positif maupun negatif pada masing-masing pribadi.

Berinteraksi dengan simbol-simbol yang ada pada teknologi terkhusus samrtphone, menurut George Herbert Mead sebagai penganut dari Weber, yang pada dasarnya adalah penganut teori sosial-psikologis yang terutama untuk penyelidikan sosiologis, mengatakan bahwa antara individu yang satu dengan individu yang lain berinteraksi satu sama lain diwujudkan dengan adanya suatu tindakan atau perilaku. Walaupun tidak semua perilaku berlandaskan dengan rasional, rasional hadir dalam diri melalui pemikiran, dalam berinteraksi muncul sebuah penggunaan simbol karena simbol inilah muncul akibat dari kebutuhan manusia untuk berinteraksi dengan orang 
lain hal ini tidak terpelas pada penggunaan smartphone. Beberapa konsep pemikiran Mead (Jhonson 1986: 17), yakni :

Mind (pikiran) Mend memandang akal budi bukan sebagai benda, melainkan sebagi proses sosial yang awalnya bertindak melalui suatu proses mental, yang artinya bahwa antara aksi dan reaksi terdapat suatu proses yang melibatkan pikiran atau kegiatan mental, dan menghasilkan sebuah simbol baik berupa bahasa isyarat, kata-kata meski tidak melihat secara langsung atau gerak gerik fisiknya, suatu perbuatan bisa mempunyai arti kalau seseorang bisa menggunakan akal budinya untuk menempatkan dirinya sendiri di dalam diri orang lain, sehingga bisa menafsirkan pikiran dengan baik, selain itu bukan hanya akal budi namun tidak terlepas dari situasi sosial yang memberikan arti kepada sesuatu.

Dalam penggunaan smartphone didasari oleh akal budi mereka atau pemikiran yang melahirkan sebuah simbol, seperti dalam penggunan game online mereka merasakan ketika lawannya kalah atau menang. Atau ketika mereka berkomunikasi melalui beberapa media sosial. Mereka mampu merasakan dan berfikir sama yang dirasakan oleh lawan komunikasinya, yang munculmya karakter-karakter perasaan yang bisa dikirimkan. Selain itu self (diri) dimana dengan kesadaran akan sesuatu mempunyai kemampuan untuk berfikir dan melalukan suatu tindakan, melalui sosialisasi, dan society (masyarakat) yang melihat ruang lingkup mikro, artinya organisasi sosial tempat akan dan serta diri muncul. Diketahui bahwa masyarakat ada sebelum individu dan proses mental atau berfikir muncul dalam masayarakat. Dengan hal ini mempunyai arti bahwa manusia bertindak berdasarkan atas makna-makna, dimana makna tersebut didapatkan dari interaksi dengan orang lain, serta maknamakna itu terus berkembang dan disepurnakan pada saat interaksi itu berlangsung. 
Konsumsi berada dalam satu tatanan pemaknaan pada satu objek, satu sistem, atau kode tanda. Suatu tatanan manipulasi tanda, manipulasi objek sebagai tanda, satu sistem komunikasi, satumoralitas, satu neralisasi proses fashion secara kombinatif. Menciptakan isolasi dan mengindividu, satu pengkekang orang secara bawah sadar, baik dari sistem tanda dan dari sistem sosial, ekonomi, dan politik. Konsumsi adalah satu stuktur (atau fakta sosial Durkheim) yang bersifat eksternal dan bersifat memaksa individu. Individu dipaksa untuk menggunakan sistem tersebut, ideologi yang terkait dengan sistem mengarahkan orang untuk percaya segala kepalsuan, bahwa mereka kaya, puas, bahagia dan terbebaskan.

Usaha untuk membentuk perilaku sosial yang baik, pelajar merupakan cerminan dari nilai-nilai tertentu yang nyata. Bahwa lingungan keluargalah yang sangat berperan penting, serta lingkungan sosial berpengaruh terhadap bentuk perilaku manusia yang berwujudkan dengan nilai-nilai teretntu. Oleh sebab itu keluarga menjadi fungsi utama untuk mendidik dan membina aspek prilaku pada diri pelajar, sebab dengan semakin jelasnya perilaku dan sikap lingkungan terhadap nilainilai hidup tertentu dan moral. Maka semakin kuat pula pengaruhnya untuk membentuk atau meniadakan suatu tingkah laku yang sesuai (atau tidak sesuai). 


\section{BAB V}

\section{KESIMPULAN DAN SARAN}

\section{A. Kesimpulan}

Berdasarkan hasil penelitian dan pembahasan yang telah diuraikan, maka dapat dikemukakan kesimpulan sebagai berikut:

1. Penggunaan smartphone diseluruh kalangan terutama pada pelajar dilatar belakangi oleh berbagai faktor, baik dilihat dari faktor (a) pribadi, yakni adanya keinginan diri sendiri, (b) psikologi, yakni adanya dorongan, motivasi, serta persepsi dalam menggunakan smartphone, dan (c) sosial, yakni adanya status sosial keluarga, teman yang menjadi faktor mendorong melatarbelakangi menggunakan smartphone.

2. Dengan menggunakan teknologi smartphone, telah tergambarkan bahwa terjadi perubahan perilaku sosial yang dialami oleh para pelajar terkhusus SMA Negeri 3 Makassar. Perubahan perilaku sebelum dan sesudah menggunakan smartphone seperti adanya kepercayan diri, mandiri, diterima atau ditolak oleh orang lain, mudah bergaul, perilaku pamer dan daya saing yang tinggi.

3. Dengan penggunaan smartphone di dalam lingkung sekolah memberikan dampak positif yakni memudahkan mendapatkan sumber belajar, memudahkan berkomunikasi, mampu meningkatkan popularitas. Memberikan sebuah kenikmatan tersendiri terhadap dunia hiburan yang menjanjikan.Negatifnya 
berpengaruh kesehatan atau radiasi cahaya, kesenjangan berinteraksi, hubungan palsu, serta terkhusus mengalami kecanduan.

\section{B. Saran}

Adapun saran-saran yang hendak diberikan terkait dengan kesimpulan dari hasil penelitian di atas, adalah sebagai berikut:

4. Membangun sistem pembinaan pelajar terkhsusus dengan berbasis masyarakat. Artinya mulai dari pembinaan orang tua, guru di sekolah maupun masyarakat pada umumnya patut memberikan penekanan-penekann disiplin dalam penggunaan smartphone sebagai langkah menciptakan kewaspadaan terhadap perilaku pelajar dalam perkembangan teknologi terutama pada smartphone.

5. Bagi para pengiklan sebaiknya dalam mempromosikam produk-produknya seharusnya melihat tujuan utama dalam mengingklam yang baik, agar para generasi tidak mudah meniru mode atau trend masa kini yang mereka belum pahami.

6. Memberikan peningkatan pemahaman pelajar terhadap nilai-nilai ajaran agama dan kearifan lokal merupakan suatu sifat yang urge. Oleh sebab itu para orangtua, sekolah dan masyarakat saling bekerja sama untuk membangun solidaritas terhadap setiap penyalangunaan teknologi smartphone. Baik pemahaman tentang dampak positif maupun dampak negatif. 


\section{DAFTAR PUSTAKA}

Adlin Alfathri.2006. Resistensi Gaya Hidup : Teori dan Realitas. Yogyakarta: Jalasutra.

Angger Ben. 2012. Teori Sosial Kritis. Yogyakarta: Kreasi Wacana Offset.

.Arikunto, Suharsini. 2002. Prosedur Penelitian (Suatu Pendekatan atau Praktek). Jakarta: Rineka Cipta .

Burgan Bungin. 2006. Sosiologi Komunikasi. Jakarta: Kharisma Putra Utama.

Budi Santoso, Satmoko.2009. Menu Celana Dalam .Jakarta: Diva Press.

Dwi, Narko. 2004. Sosiologi Teks Pengantar dan Terapan. Jakarta: Pernada Media.

Featherstone Mike. 2008. Postmodernisme dan Budaya Konsumen. Yogyakarta: Pustaka Pelajar.

Henslin, H. James. 2006. Sosiologi dengan Pendekatan Membumi. Jilid I dan II. Edisi 6. Jakarta:Rineka Cipta.

Idi Abdullah. 2014. Sosiologi Pendidikan. Jakarta: PT. RajaGrafindo Persada.

Jean Baudrillard. 2004. Masyarakat Konsumsi. Yogyakarta: Kreasi wacana

Jhon W. Santrock, Perkembangan Anak, terjemahan Mila Rachmawati dan Anna Kuswanti, ( Jakarta : Erlangga, 2007 )

Jhonson, Doyle Paul. 1986. Sosiologi Klasik dan Modern. Jakarta: Gramedia Pustaka.

Johnson Carla \& Lee Monle. 2004. Prinsip-Prinsip Pokok Periklanan Dalam Persfektif Global.Jakarta: Prenada.

Kadir, Abdul \& Triwahyuni/C.H. 2003. Pengenalan Teknologi Informasi. Yogyakarta:Penerbit Andi Yogyakarta

KJ. Veeger. 1985. Realitas Sosial, Refleksi Filsafat Sosial atas Hubungan Individu Masyarakat dalam cakrawala Sosiologi. Jakarta: Gramedia hlm 224. 
Nanang Martono. 2014. Sosiologi Perubahan Sosial. Jakarta: PT. RajaGrafindo Persada.

Mcrobbie Angela. 2014. Postmodernisme dan Budaya Pop. Bantul. Krasi Wacana Offset.

Maryanski Alexander dan Turner H. Jonathan.2010. Fungsionalisme. Yogyakarta: Pustaka pelajar.

Moleong, Lexy. J. 2001. Metodologi Penelitian Kualitatif. Cetakan ke-13. Bandung: Remaja Rosdakarya.

Miarso. 2007. Menyemai benih Teknologi Pendidikan. Jakarta: Pustekom Diknas

Misty E, V. 2007 dan Gary B. S., Thomas J,C. 2007. Discovering Computers Fundament als, 3thed (Terjemahan). Jakarta: Salemba Infotek

Ningsih Sunar, 2008, perilaku Konsumtif Remaja (kasus di Kelurahan Pandang Kota Makassar)” Skripsi. Tidak diterbitkan. Univeritas Negeri Makassar.

Nazir, Mohammad (1999). Metode Penelitian. Jakarta: Erlangga

Ratna, Nyoman Kutma. 2010. Metodologi Penelitian (Kajian Budaya dan Ilmu Sosial Hummaniora Pada Umumnya). Yogyakarta: Pustaka Pelajar.

Rasak Daruma, Sulaiman Samad \& Mustafa. 2008. Perkembangan Peserta Didik. Makassar: Fakultas Ilmu Pendidikan UNM

Ritzer, George. 2010. Sosiologi Ilmu Pengetahuan Berparadigma Ganda. Jakarta: Raja Grafindo Persada.

Ritzer George. 2013. Masyarakat Konsumsi. Yogyakarta: Kreasi Wacana.

Raharjo, A. 2002. Cybercrime: pemahaman dan Upaya Pencegahan Kejahatan Bertegnologi. Bandung: PT. Citra Aditya Bakti. .

Soekanto, Soerjono. 2003. Sosiologi Suatu Pengantar. Jakarta: Raja Grafindo Persada.

Scott, Jhon. 2011. Sosiologi The Key Concepts. Jakarta: RajaGrafindo Persada.

Skinner . F.B. 2013. Ilmu Pengetahuan dan Perilaku Manusia. Yogyakart: Pustaka pelajar.

Storey John. 2010. Cultural Studies dan kajian Budaya Pop. Yogyakarta: Jalasutra. 
Satori, Djam'an dan Komariah, Aan. 2010. Metodologi Penelitian Kualitatif. Bandung: Alffabeta.

Soemardjan, Selo. 1991. Perubahan Sosial di Yogyakarta. Yogyakarta: Gadjahmada University Press.

Triwahyuni, Terra dan Kadir. 2003. Pengenalan Teknologi Informasi. Yogyakarta: Andi Offset.

\section{BAHAN PUSTAKA INTERNET}

http://www.newmediafest.net. indonesia pengguna smartphone terbesar se asia tenggara (Online) diakses pada tanggal 7 desember 2015.

http://id.wikipedia.org/wiki/teknologi informasi $\quad$ komunikasi,(Online) $\quad$ diakses 7 desember 2015).

(http:elib.unikom.ac.id/fles/disk1/642/jbptunikompp-gdl-ernisuryan-32065-8unicom_e-i-pdf) diakses 12 desember 2015 
Lampiran 1. Instrumen Penelitian

\begin{tabular}{|c|c|c|c|}
\hline No & Fokus Masalah & Deskriptor & Sumber \\
\hline 1 & $\begin{array}{l}\text { Berbagai faktor } \\
\text { dalam penggunaan } \\
\text { smartphone }\end{array}$ & $\begin{array}{l}\text { a. Faktor pribadi } \\
\text { b. Faktor psikologi } \\
\text { c. Faktor sosial }\end{array}$ & $\begin{array}{l}\text { Wawancara } \\
\text { Observasi }\end{array}$ \\
\hline 2 & $\begin{array}{l}\text { Gambaran perubahan } \\
\text { perilaku pelajar } \\
\text { dalam penggunaan } \\
\text { smartphone }\end{array}$ & $\begin{array}{l}\text { a.Kecenderungan perilaku peran } \\
\text { b.Perilaku dalam hubungan sosial } \\
\text { c. Kecenderungan perilaku agresif }\end{array}$ & $\begin{array}{l}\text { Wawancara } \\
\text { Observasi }\end{array}$ \\
\hline 3 & $\begin{array}{l}\text { Dampak penggunaan } \\
\text { smartphone pada } \\
\text { pelajar SMA Negeri } \\
3 \text { makassar }\end{array}$ & $\begin{array}{l}\text { a. Positif } \\
\text { b. Negatif }\end{array}$ & $\begin{array}{l}\text { Wawancara } \\
\text { Observasi }\end{array}$ \\
\hline
\end{tabular}


Lampiran 2. Format Panduan Wawancara

\begin{tabular}{|c|c|c|}
\hline No & Fokus masalah & Arah pertanyaan \\
\hline 1. & $\begin{array}{l}\text { Faktor yang mendorong pelajar } \\
\text { SMA Negeri } 3 \text { Makassar. }\end{array}$ & $\begin{array}{l}\text { Hal yang mendorong pelajar } \\
\text { menggunakan smartphone yang diihat } \\
\text { dari aspek pribadi, psikologi dan sosial }\end{array}$ \\
\hline 2. & $\begin{array}{l}\text { Gambaran perubahan perilaku } \\
\text { pelajar SMA Negeri } 3 \text { Makassar } \\
\text { yang menggunakan smartphone }\end{array}$ & $\begin{array}{l}\text { Hal yang terpengaruhi oleh penggunaan } \\
\text { smartphone sebelum dan sesudah } \\
\text { penggunaan baik dilihat dari perilaku } \\
\text { pribadi, hubungan sosialnya, maupun } \\
\text { perilaku agresif-agresifnya }\end{array}$ \\
\hline 1. & $\begin{array}{l}\text { Dampak penggunaan smartphone } \\
\text { terhadap pelajar SMA Negeri } 3 \\
\text { Makassar }\end{array}$ & $\begin{array}{l}\text { Hal yang menjadi dampak, baik dampak } \\
\text { positif dan dampak negatif }\end{array}$ \\
\hline
\end{tabular}


Lampiran ke 3. Pertanyaan :

1. Apa yang dirasakan sebelum memiliki dan menggunakan smartphone?

2. Apa yang dirasakan setelah menggunakan smartphone?

3. Sejak kapan menggunakan smartphone?

4. Berapa besar anda mengeluarkan uang untuk membeli kuota internet, per hari atau perbualnnya?

5. Apa saja kegunaan smartphone dalam pembelajaran?

6. Berapa smartphone pelajar minimal gunakan?

7. Kapam waktu dibolehkan pelajar menggunakan smartphone?

8. Adakah mata pelajaran menggunakan smartphone?

9. Bagaimana cara penggunaan smartphone di sekolah?

10. Mengapa mesti menggunakan smartphone buka buku paket?

11. Apakah ada aplikasi yang digunakan untuk pembelajaran?

12. Apakah ada ketentuan dari pihak sekolah untuk menggunakan smartphone?

13. Adakah tata tertib yang dibuat untuk penggunaan smartphone?

14. Bagaimana dampak baiknya yang dirasakan dalam penggunaan smartphone?

15. Bagaimana dampak buruknya yang dirasakan dalam penggunaan smartphone? 
Lampiran 4. Deskripsi Informan dan Hasil Wawancara

1. Nama

Hari/ tanggal wawancara : kamis, 17 Maret 2016

Tingkat pendidikan : SMA Negeri 3 Makassar

Umur

Argumennya:

“ smartphone membantuki, kalau mau mauki buka kamus bisaki buka saja, terus ngetrenki sekarang, apa lagi kalau harga yang mahal kaya Samsung itu bisa aa saja di dapatkan.”

2. Nama

Hari/ tanggal wawancara

Tingkat pendidikan

Umur
: Saskia Nur Fiwisya

: kamis, 17 Maret 2016

: SMA Negeri 3 Makassar

: 17 tahun

Argumenya:

“zamannyami sekarang orang pake jadi itu lagi yang pake, baru kebutuhan juga, ada mata pelajarn yang dibiarkan pada saat proses belajar mengajar, baru kalau smartphone di pake bisaki main game"

3. Nama

: Muh. Raja Pratama

Hari/tanggal wawancara

: jumat, 18 Maret 2016

Tingkat pendidikan

: SMA Negeri 3 Makassar 
Umur

: 17 tahun

Argumennya;

"saya tidak terlaluja menggunakan smartphone, ituji kalau disuruh lagi, atau kaya lagi sendiri ndak ada teman-teman, tidakji ku pegang terusji malasjaa palingan kusimpan di tas, itu saja kalau biasa istirahat ada tugas di kasi baru ku pakai”
4. Nama
: Muh. Rifky imam
Hari/tanggal wawancara : senin, 22 Maret 2016
Tingkat pendidikan
: SMA Negeri 3 Makssar
Umur
: 16 Tahun

Argumentasi:

" mau- mauta tooh karena kan ini kebutuhan, susahki juga kalau tidak ada, bru semua oeang smartphone mi na beli, masa mauki ketinggalan, tidk dirasa kalau tidak pkeki”.

5. Nama

: Dra. Samsudduha

Hari/tanggal wawancara : senin 22 Maret 2016

Tingkat pendidikan : SMA Negeri 3 Makssar

Umur

Argumennya

“memang di sekolah ini kita sangat menganjurkan para pelajar menggunakan smartphone, dengan alasan smartphone itu membantu dalam pembelajaran, 
kemudian ada pembelajaran melalui qipper school, di mana belajar itu tetap berjalan bisa menguasai tugas maupun materi diberikan, bisa mendapat umpan balik dengan pekerjaan yang mereka kerjakan, bisa belajar tanpa batas, di rumah di mana pun selama smartphonenya itu bisa mendonloadnya. Pelajar dan guru dipadukan melalui online. Materi dibuat oleh guru sendiri, menentukan pekerjaan rumah pelajar, kemudian diberikan dan pelajar bisa mengerjakannnya. Jadi sangat membantu smartphone"
6. Nama
: Dra. Akira Dewi Intang
Hari/tanggal wawancara
: senin 22 maret 2016
Tingkat pendidikan
: SMA Negeri 3 Makssar
Umur
: 51 tahun

\section{Argumentasi}

"cara penggunaan smartphone itu di sekolah ini, bisa digunakan saat pembelajarn berlamgsung tergantung dari gurunya masing-masing mata pelajaran, ketika di buku tidak ada, dibiarkan mencari di internet, tapi ada juga pada saat dibiarkan menggunakan, ada yang tidak terlalu fokus dengan apa yang disuruhkan, ada yang suka main, jadi selalu di awasi, apa lagi itu kalau kita tidak keliling melihat pekerjaannya, disitu saja diam tunduk pakai itu smartphonenya. Bahkan ada beberapa kejadian itu gurunya sambil menerangkan di depan ada pelajar dibelakang apa lagi yang nakal-nakal melihat video tidak layak mereka nonton dikirimkan oleh temannya lewat 
bluetooth, temannya disebelah di kelas lain, langsung panggil guru BK untuk diberikan sangsi, itu banyak di kelas-kelas yang bukan unggulan, tapi pelajar disini sangat aktif mengikuti ektrakurikuler bahkan siapa pun,tidak memandang dia nakal atau pintar, dibebaskan memilih minatnya sehingga itu juga menambah penilaian, banyak yang nakal di kelas tapi pintar dalam bidang olahraga, musik, dan mendapatkan juara ketika lomba, jadi kami guru tidak melarang untuk berkreasi memilih minat sesaui bakat mereka.

$\begin{array}{ll}\text { 7. Nama } & : \text { Muh. Fadli } \\ \text { Hari/tanggal wawancara } & : 15 \text { Februari } 2016 \\ \text { Tingkat pendidikan } & : \text { SMA Negeri } 3 \text { Makssar } \\ \text { Umur } & : 16 \text { tahun }\end{array}$

\section{Argumentasi}

“saya merasakan sekali itu dampaknya kalau lama chatting sma teman bisa tengah malam, besoknya tidak bisamaki bangun pagi karena mengantuk, biasa mata pedis gara-gara seharian pakai, biasa juga itu lupa makan, tapi banyak teman di dapat dari luar, sklian belajar bahasa -bahasanya “
8. Nama
: Amirullah S.Sos
Hari/tanggal wawancara
: 18 April 2016
Tingkat pendidikan
: SMA Negeri 3 Makssar
Umur
: 43 tahun 


\section{Argumentasi}

"Kami guru dan staff menghimbau ketika upacara, apel pagi selalu mengontrol pelajar yang menggunakan, langsung menegur kalau melihat mereka menggunakan smartphonenya. Pasti kita bertanya apa dilihat, mendekati meraka dengan baik, langsung menegur. Jadi cara mengontrol itu bukan hanya guru BK, namu semua guru di sekolah mulai dri kepala sekolah smpai ke satpam dn penjaga kantin kalau ada pelajar yang dicuragai menggunakan smartphonenya dengan tidak benar kangsung laporkan. Jadi bisa cepat ditindak lanjuti, jadi harus saling bekerja sama untuk mencegah kejadian yang buruk. Tapi ada juga pelajar itu yang memang dari awal masuk tidak berubah, terkadag ditegus satu dua kali tidak jerah, jadi kami menyurati orangtuanya.

9. Nama

: Drs. Amir

Hari/tanggal wawancara

: senin, 18 April 2016

Tingkat pendidikan

: SMA Negeri 3 Makssar

Umur

: 50 tahun

Argumentasi

"Di sekolah ini pelajar-pelajarnya itu menengah kebawah, ada juga anak pejabatan tapi tidak terlalu banyak, berapa dari non islam juga, memang kalau diliat pelajar sekarang itu ada beberapa yang kalangan kebawah kelihatan hobby nya itu tinggi, selerah mereka tinggi, pakai smartphone yang mahal, tapi tidak terlalu pintar juga dikelas, sering mengnggu temannya yang 
sedang belajar, pindah-pindah tempat duduk kita juga gurunya terjadang bingung memberikan nilai. Pakai terus itu smartphone nya, apa lagi kalau jam istirahat bisa itu di dalam saja itu diruangannya smpai jam masuk tidak keluar-keluar, itu mi mungkin pengaruhnya semuai itu tapi bagus juga itu kalau ada smartphone karena membantu pelajar yang lain dalam belajar.

10. Nama

Hari/tanggal wawancara

Tingkat pendidikan

Umur
: Dra. ariani

: selasa 18 April 2016

: SMA Negeri 3 Makssar

: 52 tahun

\section{Argumentasi}

"Di sekolah ini termasuk salah satu sekolah percontohan di kota makassar, dan memnag sesuai dengan visi kita disekolah ini kan mampu mengenal dunia teknologi dan pengembangan pengetahuan, jadi pelajar pun berhak untuk mengetahui itu semua melalui lah smartphone mereka. Kami disni membuka kelas khusus unggulan, jadi semua pelajar setiap kelas itu dilihat dinilai dan dipertimbangkan untuk layak masuk dikelas khusus, kelas khusus ini dilaksanakan diluar jam pelajaran sekolah, jadi bagi yang berprestasi di kelasnya masing-masing bisa lebih berprestasi lagi mengasah mengetahuannya didalam kelas tersebut, guru-guru pun sangat tekut mengajarnya. Jadi pelajar di sekolah ini semakin lama akan semkin banyak 
termotivasi untuk lebih belajar lagi, dan tidak melakukan hal-hal negatif dengan penggunaan smartphone. 
Lampiran 6. Daftar Informan

\begin{tabular}{|c|l|c|c|c|}
\hline No & \multicolumn{1}{|c|}{ Nama } & Jenis kelamin & Umur & Pekerjaan \\
\hline 1 & Amlyana & Perempuan & 16 tahun & Pelajar \\
\hline 2 & Ichsan rifky ramadhan & Laki-laki & 16 tahun & Pelajar \\
\hline 3 & Anisya namira syahrial & Perempuan & 17 tahun & Pelajar \\
\hline 4 & A.Muh. Danu tirta & Laki-laki & 15 tahun & Pelajat \\
\hline 5 & Hisbull djabbar & Laki-laki & 15 tahun & Pelajatr \\
\hline 6 & Jumniarti & Perempuan & 16 tahun & Pelajar \\
\hline 7 & Kevin jeremi & Laki-laki & 17 tahun & Pelajar \\
\hline 8 & Muh.Arif & Laki-laki & 15 tahun & Pelajar \\
\hline 9 & Muh. Fikri djami & Laki-laki & 15 tahun & Pelajar \\
\hline 10 & Dita maharani & perempuan & 17 tahun & Pelajar \\
\hline 11 & Muh. Aqil zulkarnaen & Laki-laki & 16 tahun & Pelajar \\
\hline 12 & Nur astriani & perempuan & 17 tahun & Pelajar \\
\hline 13 & Muh. Riadi arief & Laki-laki & 17 tahun & Pelajar \\
\hline 14 & Nadya khaerunnisa & perempuan & 17 tahun & Pelajar \\
\hline 15 & Nur ainun & perempuan & 16 tahun & Pelajar \\
\hline 16 & Saskia nur fiwisya & perempuan & 17 tahun & Pelajar \\
\hline 17 & Muh. Raja pratama & Laki-laki & 17 tahun & Pelajar \\
\hline 18 & Naufal akbar & Laki-laki & 16 tahun & Pelajar \\
\hline 19 & Dea muhammad fadil & Laki-laki & 16 tahun & Pelajar \\
\hline 20 & Muh. Rifky imam & Laki-laki & 16 tahun & Pelajar \\
\hline
\end{tabular}


Lampiran 7. Perbedaan Handphone dan Smartphone

\begin{tabular}{|l|l|l|l|}
\hline no & \multicolumn{1}{|c|}{ Handphone } & no & \multicolumn{1}{|c|}{ Smartphone } \\
\hline 1. & Tidak memiliki operating & 1. & Memiliki operating system (OS) \\
\hline system (OS) & $\begin{array}{l}\text { Software (perangkat lunak) } \\
\text { penyimpanan }\end{array}$ & 2. & Software (perangkat lunak) atau \\
data/dokumen terbatas & penyimpanan data/dokumen tidak terbatas \\
\hline 3. & $\begin{array}{l}\text { Kecepatan akses internet } \\
\text { terbatas }\end{array}$ & & Memiliki akses internet yang cepat \\
\hline 4. & $\begin{array}{l}\text { Tombol bukan model } \\
\text { QWERTY }\end{array}$ & Tombol model QWERTY diadaptasi dari \\
\hline 5. & Tidak dapat mengakses e- & 5. & Dapat mengakses e-mail dan memiliki \\
mail & notifikasi. \\
\hline
\end{tabular}


Lampiran 8. Jadwal Kegiatan Penelitian

\begin{tabular}{|c|c|c|c|c|c|c|c|c|}
\hline \multirow{2}{*}{ No } & \multirow{2}{*}{ Kegiatan Peneliti } & \multicolumn{6}{|c|}{ Bulan ke } & \multirow{2}{*}{ Ket } \\
\hline & & 1 & 2 & 3 & 4 & 5 & 6 & \\
\hline \multirow{5}{*}{1} & Persiapan & & & & & & & \\
\hline & - Penyusunan proposal & $\sqrt{ }$ & $\sqrt{ }$ & & & & & \\
\hline & $\begin{array}{l}\text { - Pelaksanaan seminar } \\
\text { proposal }\end{array}$ & & & $\sqrt{ }$ & & & & \\
\hline & - Perbaikan/revisi proposal & & & $\sqrt{ }$ & & & & \\
\hline & - Pengurusan izin penelitian & & & $\sqrt{ }$ & & & & \\
\hline 2 & Pengumpulan data & & & & $\sqrt{ }$ & $\sqrt{ }$ & & \\
\hline 3 & Pengolahan dan analisis data & & & & & $\sqrt{ }$ & & \\
\hline 4 & $\begin{array}{l}\text { Penyusunan laporan } \\
\text { penelitian }\end{array}$ & & & & & $\sqrt{ }$ & & \\
\hline 5 & Pelaksanaan seminar hasil & & & & & & $\sqrt{ }$ & \\
\hline 6 & Perbaikan laporan penelitian & & & & & & $\sqrt{ }$ & \\
\hline 7 & Penyajian laporan/ujian tesis & & & & & & $\sqrt{ }$ & \\
\hline
\end{tabular}


Lampiran 9. Jenis /merek smartphone yang digunakan

\begin{tabular}{|c|l|c|c|}
\hline No & \multicolumn{1}{|c|}{ Nama } & Jenis samrtphone & Aktif menggunakan \\
\hline 1 & Amlyana & Samsung & 3 tahun \\
\hline 2 & Ichsan rifky ramadhan & Iphone 4 & 3 tahun \\
\hline 3 & Anisya namira syahrial & Iphone 5 & 2 tahun \\
\hline 4 & A.Muh. Danu tirta & Oppo & 2 tahun \\
\hline 5 & Hisbull djabbar & Asus & 1 tahun \\
\hline 6 & Jumniarti & Samsung & 1 tahun \\
\hline 7 & Kevin jeremi & Samsung & 3 tahun \\
\hline 8 & Muh.Arif & Oppo & 3 tahun \\
\hline 9 & Muh. Fikri djami & Blackberry & 4 tahun \\
\hline 10 & Dita maharani & Backberry & 4 tahun \\
\hline 11 & Muh. Aqil zulkarnaen & Samsung & 1 tahun \\
\hline 12 & Nur astriani & Oppo & 2 tahun \\
\hline 13 & Muh. Riadi arief & Oppo & 2 tahun \\
\hline 14 & Nadya khaerunnisa & Blackberry & 3 tahun \\
\hline 15 & Nur ainun & Samsung & 3 tahun \\
\hline 16 & Saskia nur fiwisya & Samsung & 3 tahun \\
\hline 17 & Muh. Raja pratama & Asus & 2 tahun \\
\hline 18 & Naufal akbar & Sony & 2 tahun \\
\hline 19 & Dea muhammad fadil & Iphone 5 & 4 tahun \\
\hline 20 & Muh. Rifky imam & Sony & 3 tahun \\
\hline & & & \\
\hline & & & \\
\hline
\end{tabular}




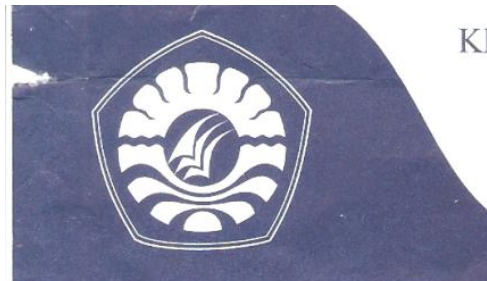

\section{KEMENTERIAN RISET, TEKNOLOGI, DAN PENDIDIKAN TINGGI UNIVERSITAS NEGERI MAKASSAR \\ FROGRAM PASCASARJANA}

Kampus UNM Gı nungsari Baru, Jl. Bonto Langkasa, Makassar-90222,

Telp. 0411) 830366, Telp./Fax. (0411) 855288,

Email: pasca@unm.ac.id, Laman: http://pps.unm.ac.id

\section{SURAT KETERANGAN PERBAIKAN UJIAN TESIS}

Berdasarkan Ujian Tesis untuk Penyusunan Tesis

$\begin{array}{ll}\text { N a m a } & \text { : Nur Inayati Saiful } \\ \text { Nomor Pokok } & : \text { 14B02017 } \\ \text { Program Studi } & : \text { Pend.IPS } \\ \text { Kekhususan } & : \text { IPS / Sosiologi } \\ \text { Judul Tesis } & :\end{array}$

Teknologi dan Perilaku Sosial Pelajar (Studi Tentang Dampak Penggunaan Smartphone di SMA Negeri 3 Makassar)

Oleh Tim Penilai, harus dilakukan perbaikan-perbaikan. Perbaikan tersebut dilakukan dan telah disetujui oleh Tim Penilai .

\begin{tabular}{|c|l|c|}
\hline No. & \multicolumn{1}{|c|}{ Nama Tim Penilai } & $\begin{array}{c}\text { Disetujui } \\
\text { Tanggal }\end{array}$ \\
\hline 2 & Prof. H. Hamdan Juhannis, MA., Ph.D. & Dr. Firdaus W. Suhaeb, M.Si.
\end{tabular}




\section{KEMENTERIAN RISET, TEKNOLOGI, DAN PENDIDIKAN TINGGI}

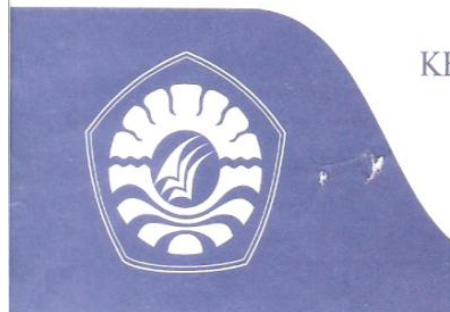

UNIVERSITAS NEGERI MAKASSAR (UNM) PROGRAM PASCASARJANA

Kampus UNM Gunungsari Baru, Jl. Bonto Langkasa, Makassar-90222, Telp. (0411) 830366, Telp./Fax. (0411) 855288,

Email: pasca@unm.ac.id, Laman: http://pps.unm.ar.id

\section{SURAT KETERANGAN PERBAIKAN SEMINAR}

Berdasarkan Seminar Usul Penelitian untuk Penyusunan Tesis

$\mathrm{N}$ a m a $\quad$ : Nur Inayati Saiful

Nomor Pokok : :14B02017

Program Studi : IPS

Kekhususan : Pendidikan Sosiologi

Judul Tesis

“Teknologi dan Perilaku Sosial Pelajar (Studi Tentang Dampak Penggunaan Smartphone di SMA Negeri 3 Makassar"

Oleh Tim Penilai, harus dilakukan perbaikan - perbaikan. Perbaikan tersebut dilakukan dan telah disetujui oleh Tim Penilai.

\begin{tabular}{|c|l|c|}
\hline No. & \multicolumn{1}{|c|}{ Nama Tim Penilai } & $\begin{array}{c}\text { Disetujui } \\
\text { Tanggal }\end{array}$
\end{tabular}

Makassar,

2016

Mengetahui :

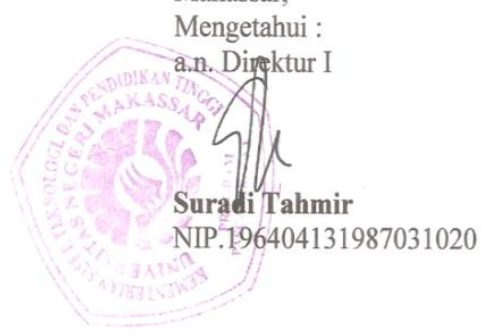

Tetap Jaya dalam Tantangan 


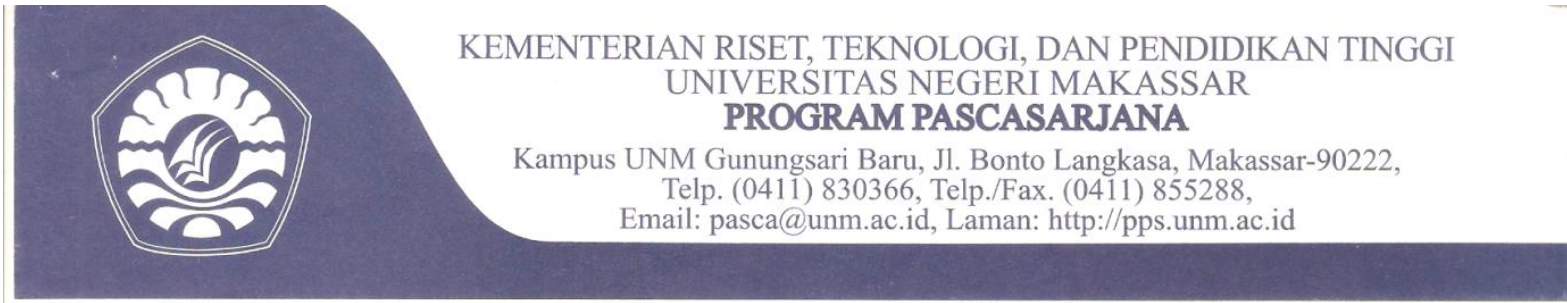

\section{SURAT KETERANGAN PERBAIKAN UJIAN TESIS}

Berdasarkan Ujian Tesis untuk Penyusunan Tesis

$\begin{array}{ll}\text { N a m a } & : \text { Nur Inayati Saiful } \\ \text { Nomor Pokok } & : \text { 14B02017 } \\ \text { Program Studi } & : \text { Pend.IPS } \\ \text { Kekhususan } & : \text { IPS / Sosiologi } \\ \text { Judul Tesis } & :\end{array}$

Teknologi dan Perilaku Sosial Pelajar (Studi Tentang Dampak Penggunaan Smartphone di SMA Negeri 3 Makassar)

Oleh Tim Penilai, harus dilakukan perbaikan-perbaikan. Perbaikan tersebut dilakukan dan telah disetujui oleh Tim Penilai .

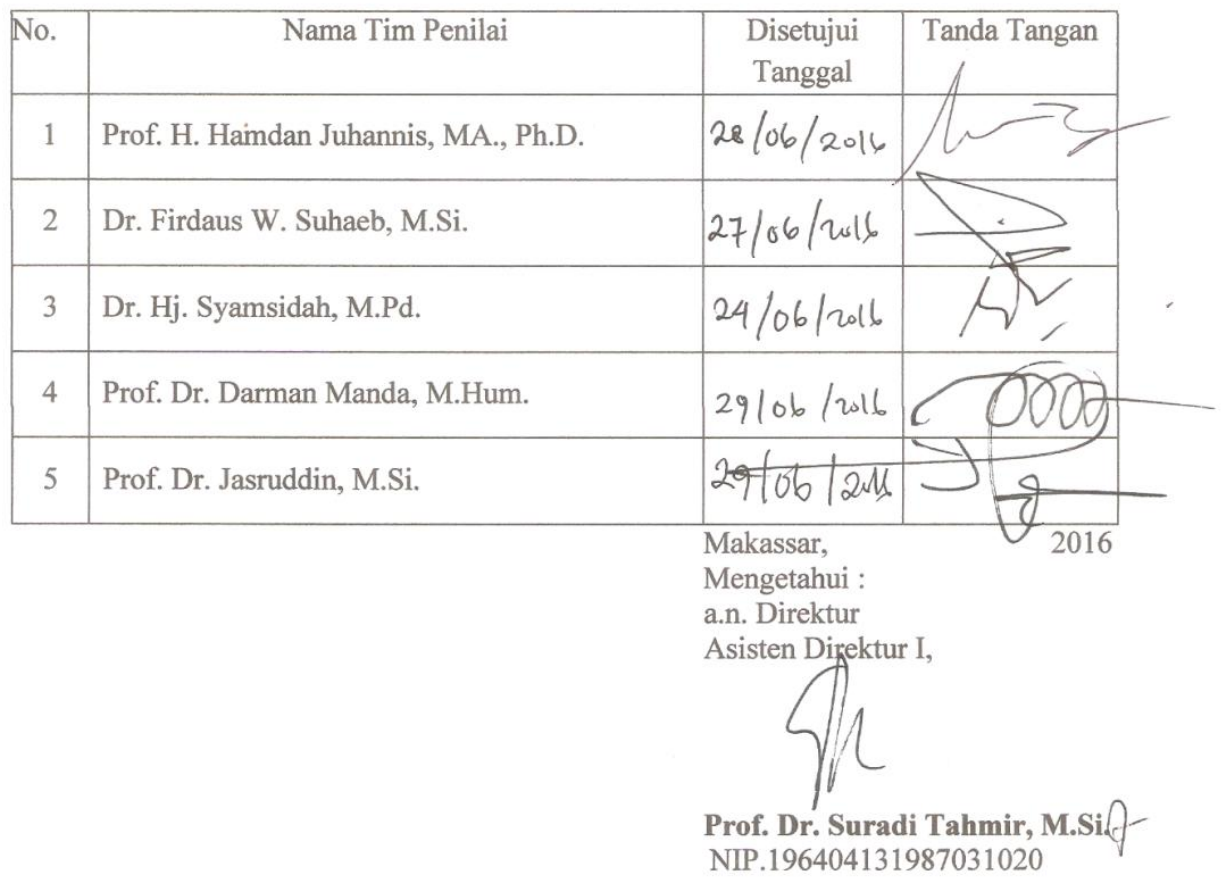

Tetap Jaya dalam Tantangan 


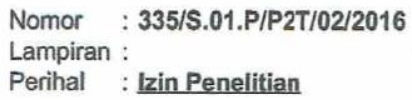

KepadaYth.

Walikota Makassar

di-

Tempat

Berdasarkan surat Direktur PPs UNM Makassar Nomor : 1253/UN36.8/KM/2016 tanggal 03 Februari 2016 perihal tersebut diatas, mahasiswa/peneliti dibawah ini:

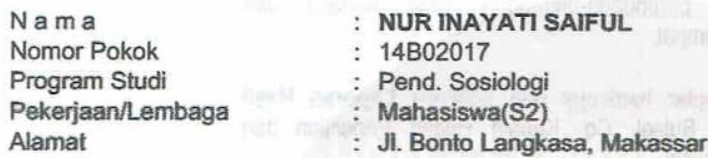

Bermaksud untuk melakukan penelitian di daerah/kantor saudara dalam rangka penyusunan Tesis, dengan judul

" TEKNOLOGI DAN PERILAKU SOSIAL PELAJAR (STUDI TENTANG DAMPAK PENGGUNAAN SMARTPHONE DI SMA NEGERI 3 MAKASSAR) "

Yang akan dilaksanakan dari : Tgl. 09 Februari s/d 30 April 2016

Sehubungan dengan hal tersebut diatas, pada prinsipnya kami menyetujui kegiatan dimaksud dengan ketentuan yang tertera di belakang surat izin penelitian.

Demikian Surat Keterangan ini diberikan agar dipergunakan sebagaimana mestinya.

Diterbitkan di Makassar

Pada tanggal : 05 Februari 2016

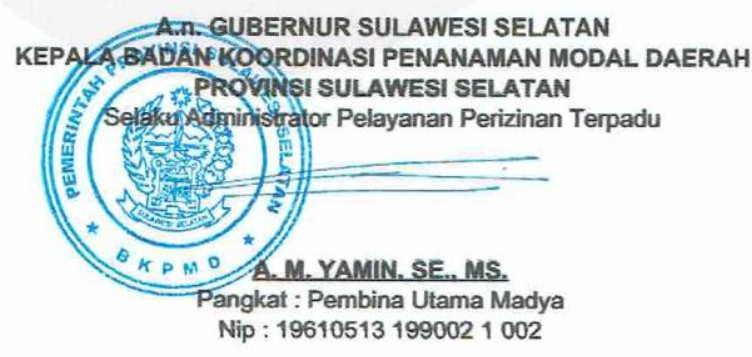

Tembusan Yth

1. Direktur PPs UNM Makassar,

2. Pertinggal. 


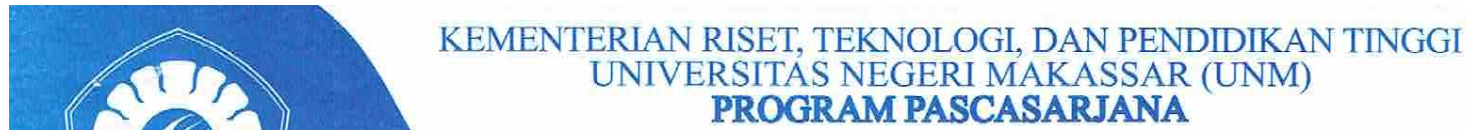

Kampus UNM Gunungsari Baru, Jl. Bonto Langkasa, Makassar-90222, Telp. (0411) 830366, Telp./Fax. (0411) 855288,

Email: pasca@unm.ac.id, Laman: http://pps.unm.ac.id

$$
\begin{array}{ll}
\text { Nomor } & : 1253 / \mathrm{UN} 36.8 / \mathrm{KM} / 2016 \\
\text { Lamp. } & : 1 \text { (satu) Proposal } \\
\text { Perihal } & \text { : Izin Penelitian }
\end{array}
$$

Yth Gubernur Provinsi Sulawesi Selatan

\section{Cq. Badan Koordinasi Penanaman Modal Daerah}

\section{Makassar}

Dengan hormat disampaikan bahwa, mahasiswa Program Pascasarjana Universitas Negeri Makassar yang tersebut di bawah ini akan melaksanakan penelitian dalam rangka penyelesaian studi magister.

$$
\begin{array}{ll}
\text { Nama } & \text { : Nur Inayati Saiful } \\
\text { Nim } & \text { : 14B02017 } \\
\text { Program Studi } & \text { : IPS. } \\
\text { Kekhususan } & \text { : Pendidikan Sosiologi } \\
\begin{array}{l}
\text { Judul Penelitian } \\
\text { "Teknologi dan Perilaku Sosial Pelajar (Studi Tentang Dampak Penggunaan } \\
\text { Smartphone di SMA Negeri } 3 \text { Makassar" }
\end{array}
\end{array}
$$

Sehubungan dengan hal tersebut di atas, dimohon kiranya yang bersangkutan dapat diberikan izin Penelitian

Atas perhatian dan kerjasama yang baik diucapkan Terima kasih.

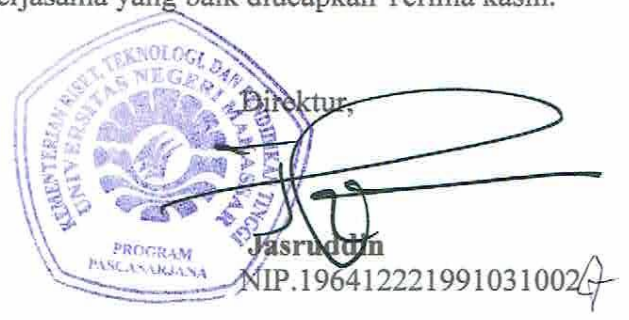

Tembusan :

- Rektor UNM (sebagai laporan)

- Asdir II PPs UNM

- KPS IPS.

- Mahasiswa yang bersangkutan 


\title{
PEMERINTAH KOTA MAKASSAR DINAS PENDIDIKAN DAN KEBUDAYAAN
}

Jl. Lețen Hertasning No. 8 Telp. (0411) 868073 Faks. 869256 Makassar 90222

Website:hitp/www.dikbud-makassar.info ; e-mail:dikbud.makassar@yahoo.com

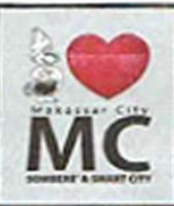

IZIN PENEIITIAN

NOMOR :070/0154/DPK/II/2016

Dasar

: Surat Kepala Kantor Badan Kesatuan Bangsa Kota Makassar Nomor : 070/390-II/BKBP/IL/2016 Tanggal 10 Februari 2016

Maka Kepala Dinas Pendidikan Dan Kebudayaan Kota

Makassar-

Kepada

\section{MENGIZINKA N}

$\begin{array}{ll}\text { Nama } & : \text { Nur Inayati Saiful } \\ \text { NIM / Jurusan } & : 14 \text { B02017/Pend.Sosiologi } \\ \text { Pekerjaan } & : \text { Mahasiswa (S2) } \\ \text { Alamat } & : \text { JL.Bonto Langkasa, Makassar }\end{array}$

Untuk

\begin{abstract}
: Mengadakan Penelitian Di SMA Negeri 3 Makassar Dalam Rangka Penyusunan Tesis di PPs UNM Makassar di Makassar dengan judul penelitian :

"TEKNOLOGI DAN PERILAKU SOSLAL PELAJAR (STUDI TENTANG DAMPAK PENGGUNAAN SMARTPHONE DI SMA NEGERI 3 MAKASSAR)"
\end{abstract}

Dengan Ketentuan sebagai berikut :

Harus melapor pada Kepala Sekolah yang bersangkutan

1. Tidak mengganggu proses kegiatan belajar mengajar di Sekolah

2. Harus mematuhi tata tertib dan peraturan di Sekolah yang berlaku

3. Hasil penelitian 1 ( satu ) examplar di laporkan kepada Kepala Dinas Pendidikan Kota Makassar

Demikian izin penelitian ini di berikan untuk di gunakan sebagaimana mestinya

Dikeluarkan di : Makassar

Pada Tanggal : 11 Februari 2016

An. Kepala Dinas Pendidikan Dan

Kebudayaan

Kasybag Umum Dan Kepegawaian

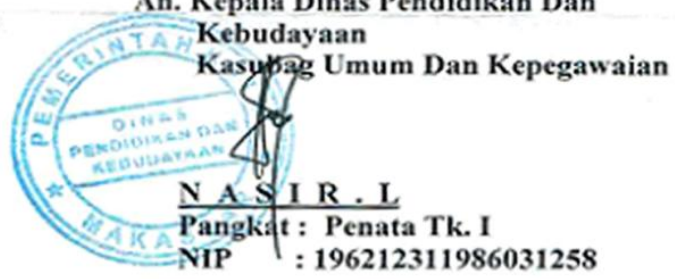


Lampiran 10. Dokumentasi

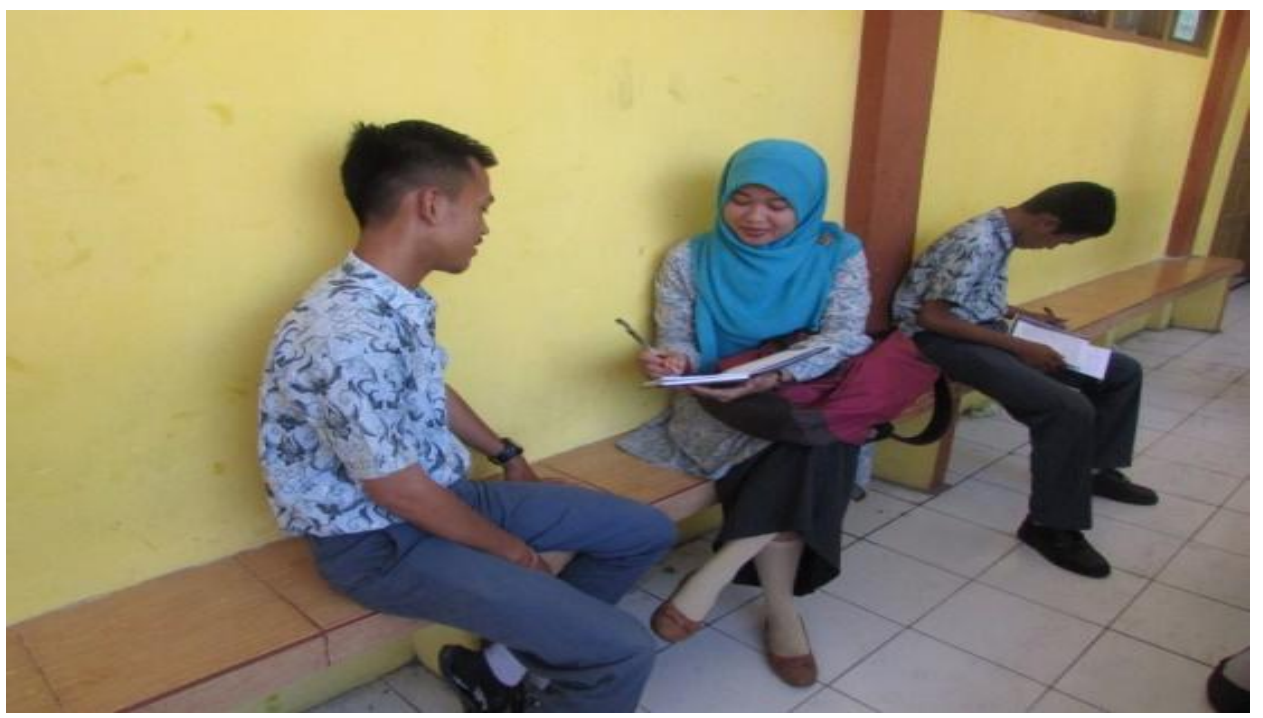

(wawancara bersama pelajar di depan kelasnya saat jam istirahat berlangsung, februari 2016)

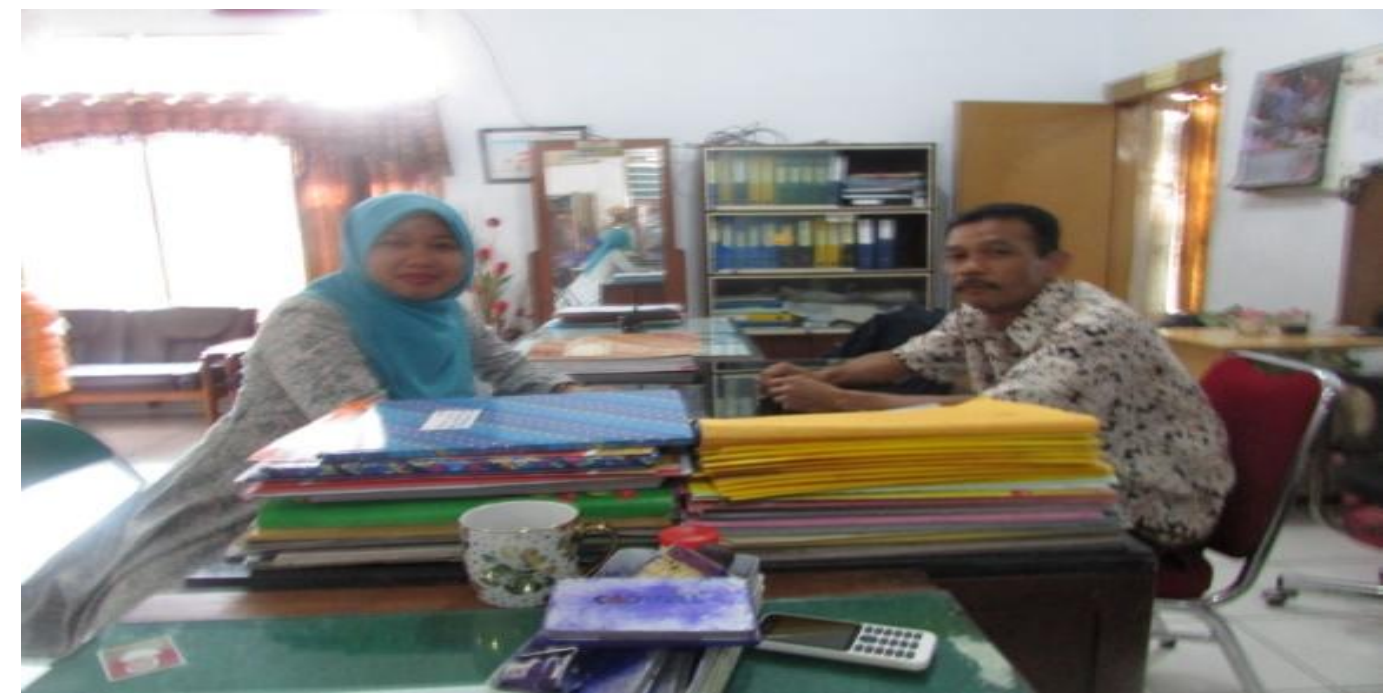

(wawancara bersama salah satu pegawai Tata Usaha, atas nama Muh. Saleh, sos.) 


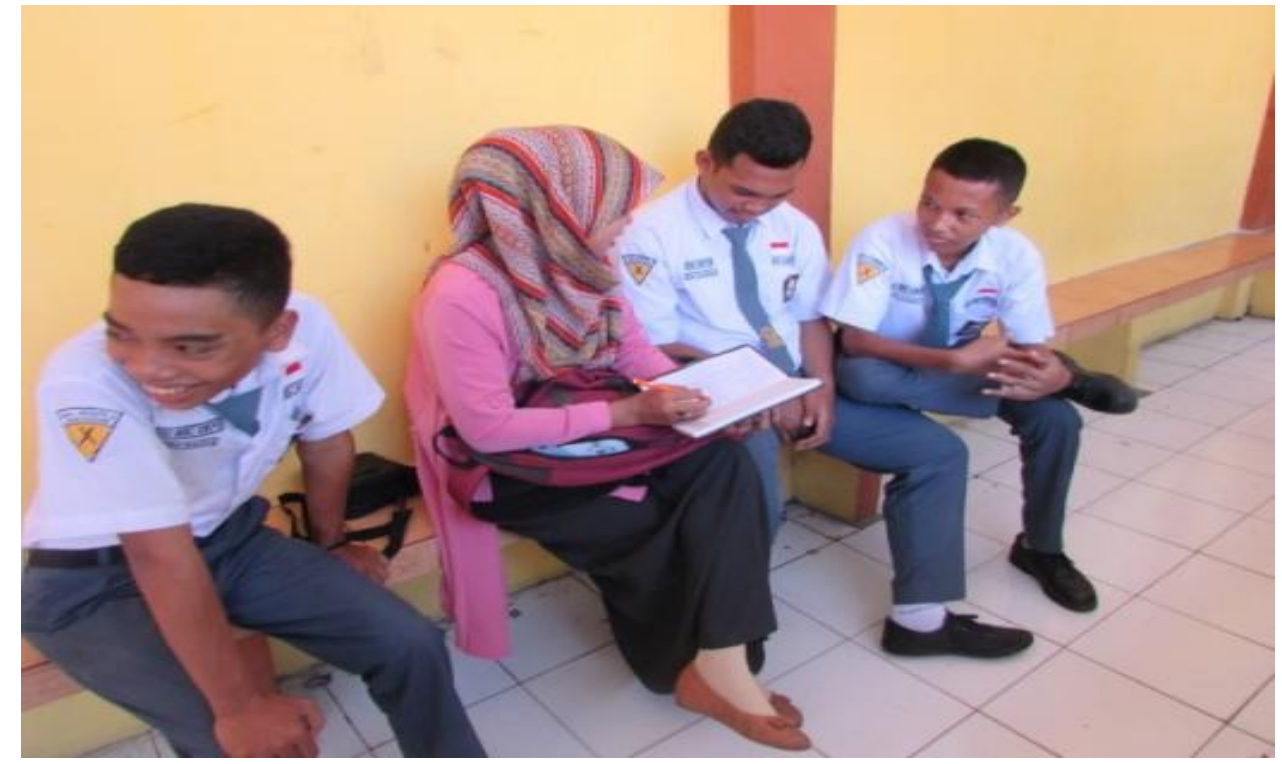

(wawancara bersama beberapa pelajar di depan kelasnya, maret 2016)

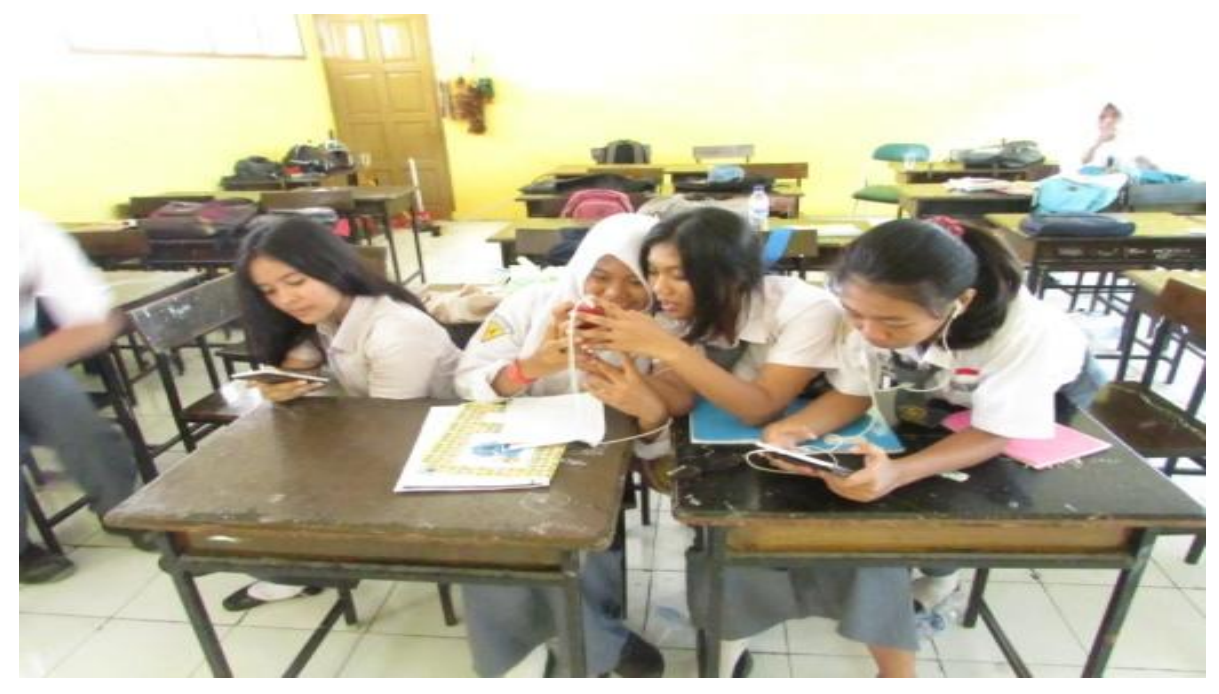

(mengamati, beberapa pelajar yang menggunakan smartphonenya, maret 2016) 


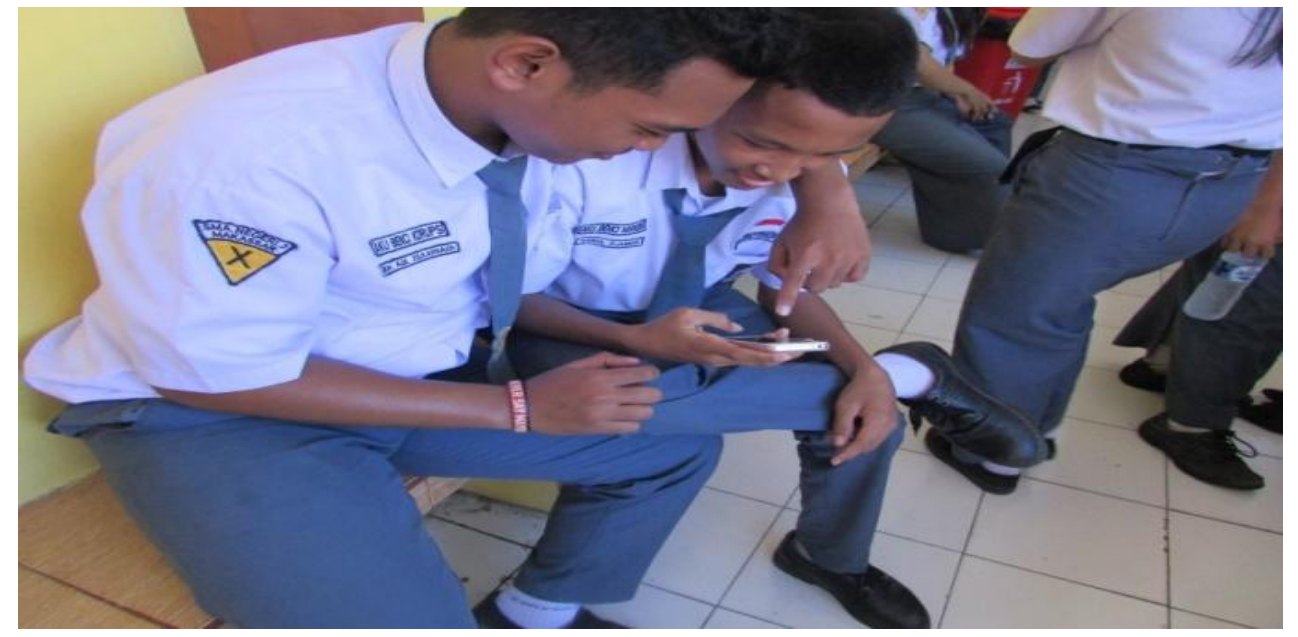

(mengamati pelajar dalam penggunaan smartphonenya, Maret 2016)

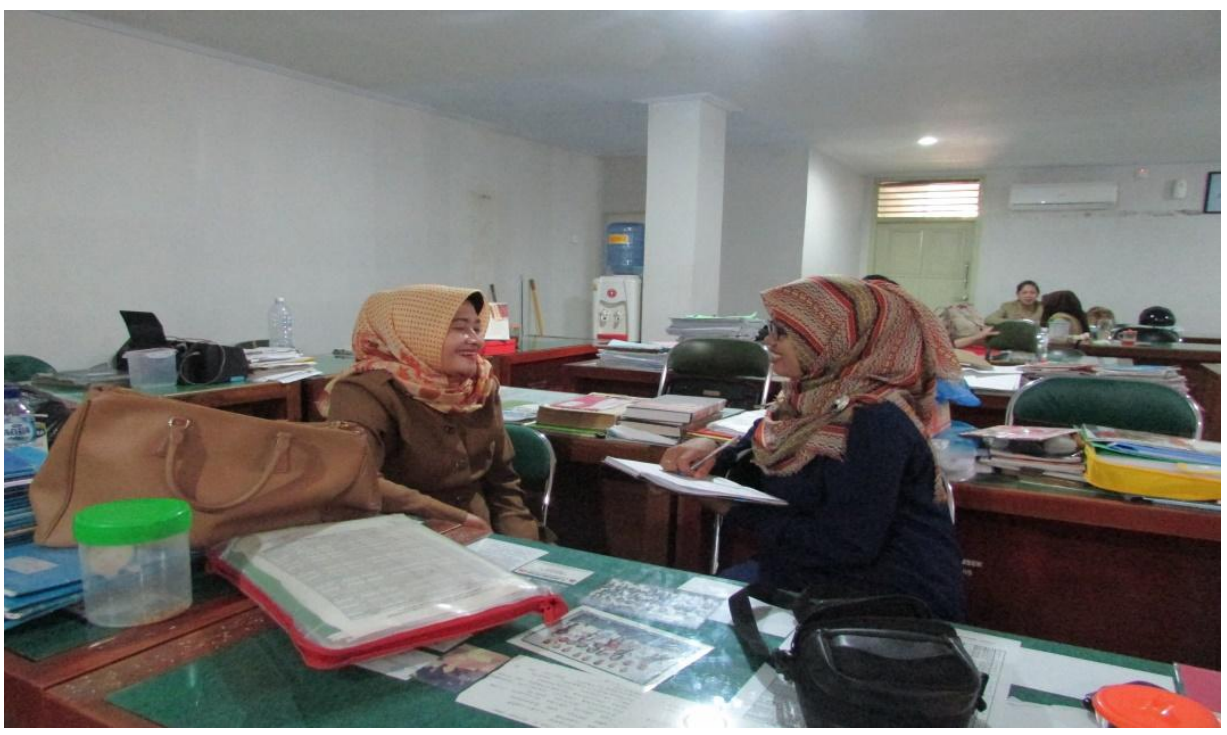

(Wawancara bersama salah satu wali kelas, atas nama Dra. Ariani) 


\section{Lampiran 11. Peta SMA Negeri 3 Makassar}

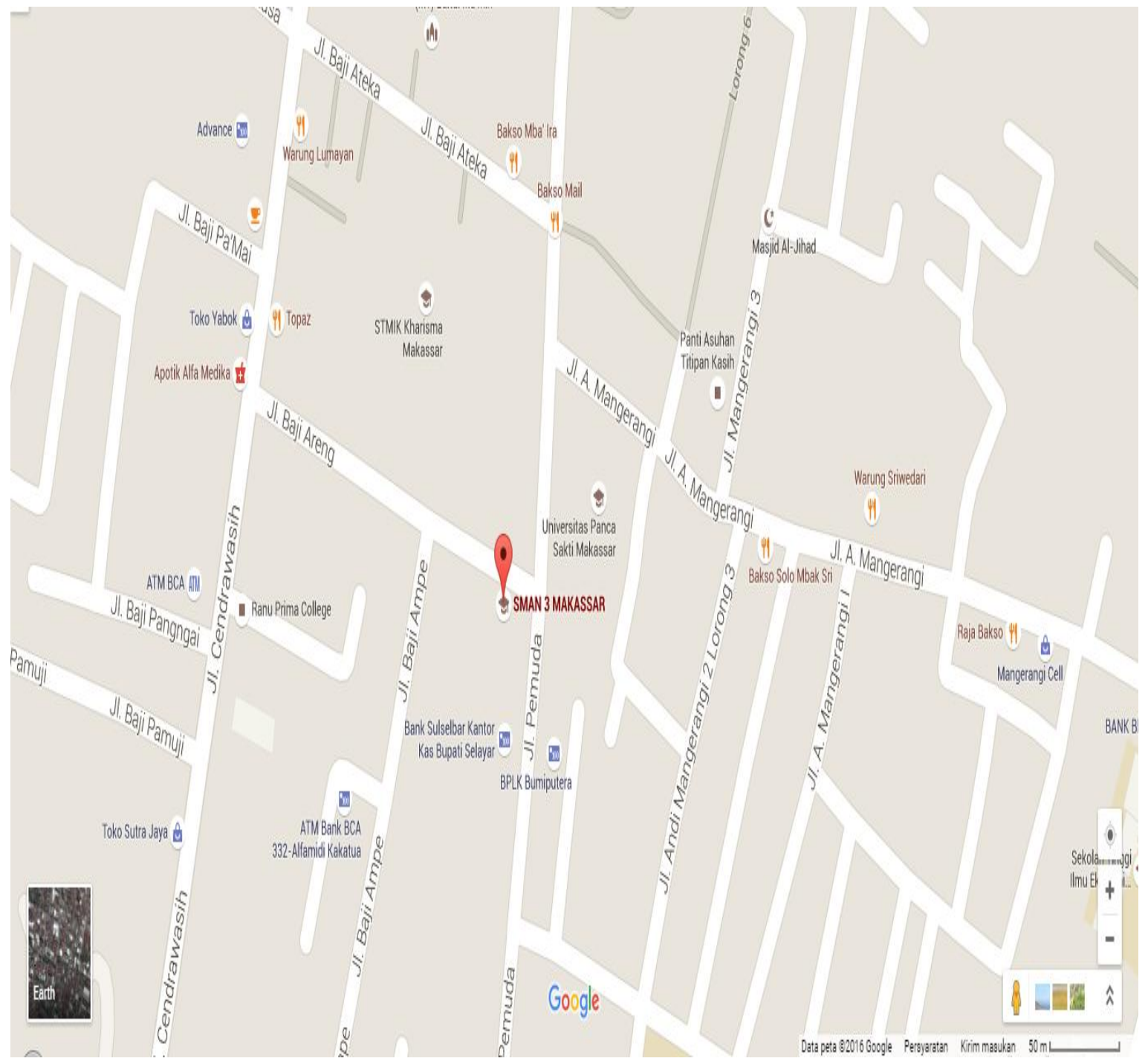


Lampiran 1. Instrumen Penelitian

\begin{tabular}{|c|c|c|c|}
\hline No & Fokus Masalah & Deskriptor & Sumber \\
\hline 1 & $\begin{array}{l}\text { Berbagai faktor } \\
\text { dalam penggunaan } \\
\text { smartphone }\end{array}$ & $\begin{array}{l}\text { a. Faktor pribadi } \\
\text { b. Faktor psikologi } \\
\text { c. Faktor sosial }\end{array}$ & $\begin{array}{l}\text { Wawancara } \\
\text { Observasi }\end{array}$ \\
\hline 2 & $\begin{array}{l}\text { Gambaran perubahan } \\
\text { perilaku pelajar } \\
\text { dalam penggunaan } \\
\text { smartphone }\end{array}$ & $\begin{array}{l}\text { a.Kecenderungan perilaku peran } \\
\text { b.Perilaku dalam hubungan sosial } \\
\text { c. Kecenderungan perilaku agresif }\end{array}$ & $\begin{array}{l}\text { Wawancara } \\
\text { Observasi }\end{array}$ \\
\hline 3 & $\begin{array}{l}\text { Dampak penggunaan } \\
\text { smartphone pada } \\
\text { pelajar SMA Negeri } \\
3 \text { makassar }\end{array}$ & $\begin{array}{l}\text { a. Positif } \\
\text { b. Negatif }\end{array}$ & $\begin{array}{l}\text { Wawancara } \\
\text { Observasi }\end{array}$ \\
\hline
\end{tabular}


Lampiran 2. Format Panduan Wawancara

\begin{tabular}{|c|c|c|}
\hline No & Fokus masalah & Arah pertanyaan \\
\hline 1. & $\begin{array}{l}\text { Faktor yang mendorong pelajar } \\
\text { SMA Negeri } 3 \text { Makassar. }\end{array}$ & $\begin{array}{l}\text { Hal yang mendorong pelajar } \\
\text { menggunakan smartphone yang diihat } \\
\text { dari aspek pribadi, psikologi dan sosial }\end{array}$ \\
\hline 2. & $\begin{array}{l}\text { Gambaran perubahan perilaku } \\
\text { pelajar SMA Negeri } 3 \text { Makassar } \\
\text { yang menggunakan smartphone }\end{array}$ & $\begin{array}{l}\text { Hal yang terpengaruhi oleh penggunaan } \\
\text { smartphone sebelum dan sesudah } \\
\text { penggunaan baik dilihat dari perilaku } \\
\text { pribadi, hubungan sosialnya, maupun } \\
\text { perilaku agresif-agresifnya }\end{array}$ \\
\hline 2. & $\begin{array}{l}\text { Dampak penggunaan smartphone } \\
\text { terhadap pelajar SMA Negeri } 3 \\
\text { Makassar }\end{array}$ & $\begin{array}{l}\text { Hal yang menjadi dampak, baik dampak } \\
\text { positif dan dampak negatif }\end{array}$ \\
\hline
\end{tabular}


Lampiran ke 3. Pertanyaan :

16. Apa yang dirasakan sebelum memiliki dan menggunakan smartphone?

17. Apa yang dirasakan setelah menggunakan smartphone?

18. Sejak kapan menggunakan smartphone?

19. Berapa besar anda mengeluarkan uang untuk membeli kuota internet, per hari atau perbualnnya?

20. Apa saja kegunaan smartphone dalam pembelajaran?

21. Berapa smartphone pelajar minimal gunakan?

22. Kapam waktu dibolehkan pelajar menggunakan smartphone?

23. Adakah mata pelajaran menggunakan smartphone?

24. Bagaimana cara penggunaan smartphone di sekolah?

25. Mengapa mesti menggunakan smartphone buka buku paket?

26. Apakah ada aplikasi yang digunakan untuk pembelajaran?

27. Apakah ada ketentuan dari pihak sekolah untuk menggunakan smartphone?

28. Adakah tata tertib yang dibuat untuk penggunaan smartphone?

29. Bagaimana dampak baiknya yang dirasakan dalam penggunaan smartphone?

30. Bagaimana dampak buruknya yang dirasakan dalam penggunaan smartphone? 
Lampiran 4. Deskripsi Informan dan Hasil Wawancara

$\begin{array}{ll}\text { 11. Nama } & : \text { Nur Astriani } \\ \text { Hari/ tanggal wawancara } & : \text { kamis, } 17 \text { Maret } 2016 \\ \text { Tingkat pendidikan } & : \text { SMA Negeri } 3 \text { Makassar } \\ \text { Umur } & : 17 \text { tahun }\end{array}$

Argumennya:

“ smartphone membantuki, kalau mau mauki buka kamus bisaki buka saja, terus ngetrenki sekarang, apa lagi kalau harga yang mahal kaya Samsung itu bisa aa saja di dapatkan."

\section{Nama}

Hari/ tanggal wawancara

Tingkat pendidikan

Umur
: Saskia Nur Fiwisya

: kamis, 17 Maret 2016

: SMA Negeri 3 Makassar

: 17 tahun

Argumenya:

“zamannyami sekarang orang pake jadi itu lagi yang pake, baru kebutuhan juga, ada mata pelajarn yang dibiarkan pada saat proses belajar mengajar, baru kalau smartphone di pake bisaki main game"
13. Nama
: Muh. Raja Pratama
Hari/tanggal wawancara
: jumat, 18 Maret 2016
Tingkat pendidikan
: SMA Negeri 3 Makassar 
Umur

: 17 tahun

Argumennya;

“saya tidak terlaluja menggunakan smartphone, ituji kalau disuruh lagi, atau kaya lagi sendiri ndak ada teman-teman, tidakji ku pegang terusji malasjaa palingan kusimpan di tas, itu saja kalau biasa istirahat ada tugas di kasi baru ku pakai”

$\begin{array}{ll}\text { 14. Nama } & : \text { Muh. Rifky imam } \\ \text { Hari/tanggal wawancara } & \text { : senin, 22 Maret } 2016 \\ \text { Tingkat pendidikan } & \text { : SMA Negeri 3 Makssar } \\ \text { Umur } & : \text { 16 Tahun }\end{array}$

Argumentasi:

“ mau- mauta tooh karena kan ini kebutuhan, susahki juga kalau tidak ada, bru semua oeang smartphone mi na beli, masa mauki ketinggalan, tidk dirasa kalau tidak pkeki”.

15. Nama

: Dra. Samsudduha

Hari/tanggal wawancara : : senin 22 Maret 2016

Tingkat pendidikan

: SMA Negeri 3 Makssar

Umur

Argumennya

“memang di sekolah ini kita sangat menganjurkan para pelajar menggunakan smartphone, dengan alasan smartphone itu membantu dalam pembelajaran, 
kemudian ada pembelajaran melalui qipper school, di mana belajar itu tetap berjalan bisa menguasai tugas maupun materi diberikan, bisa mendapat umpan balik dengan pekerjaan yang mereka kerjakan, bisa belajar tanpa batas, di rumah di mana pun selama smartphonenya itu bisa mendonloadnya. Pelajar dan guru dipadukan melalui online. Materi dibuat oleh guru sendiri, menentukan pekerjaan rumah pelajar, kemudian diberikan dan pelajar bisa mengerjakannnya. Jadi sangat membantu smartphone”
16. Nama
: Dra. Akira Dewi Intang
Hari/tanggal wawancara
: senin 22 maret 2016
Tingkat pendidikan
: SMA Negeri 3 Makssar
Umur
: 51 tahun

\section{Argumentasi}

"cara penggunaan smartphone itu di sekolah ini, bisa digunakan saat pembelajarn berlamgsung tergantung dari gurunya masing-masing mata pelajaran, ketika di buku tidak ada, dibiarkan mencari di internet, tapi ada juga pada saat dibiarkan menggunakan, ada yang tidak terlalu fokus dengan apa yang disuruhkan, ada yang suka main, jadi selalu di awasi, apa lagi itu kalau kita tidak keliling melihat pekerjaannya, disitu saja diam tunduk pakai itu smartphonenya. Bahkan ada beberapa kejadian itu gurunya sambil menerangkan di depan ada pelajar dibelakang apa lagi yang nakal-nakal melihat video tidak layak mereka nonton dikirimkan oleh temannya lewat 
bluetooth, temannya disebelah di kelas lain, langsung panggil guru BK untuk diberikan sangsi, itu banyak di kelas-kelas yang bukan unggulan, tapi pelajar disini sangat aktif mengikuti ektrakurikuler bahkan siapa pun,tidak memandang dia nakal atau pintar, dibebaskan memilih minatnya sehingga itu juga menambah penilaian, banyak yang nakal di kelas tapi pintar dalam bidang olahraga, musik, dan mendapatkan juara ketika lomba, jadi kami guru tidak melarang untuk berkreasi memilih minat sesaui bakat mereka.

$\begin{array}{ll}\text { 17. Nama } & : \text { Muh. Fadli } \\ \text { Hari/tanggal wawancara } & : \text { 15 Februari } 2016 \\ \text { Tingkat pendidikan } & : \text { SMA Negeri } 3 \text { Makssar } \\ \text { Umur } & : 16 \text { tahun }\end{array}$

\section{Argumentasi}

“saya merasakan sekali itu dampaknya kalau lama chatting sma teman bisa tengah malam, besoknya tidak bisamaki bangun pagi karena mengantuk, biasa mata pedis gara-gara seharian pakai, biasa juga itu lupa makan, tapi banyak teman di dapat dari luar, sklian belajar bahasa -bahasanya “
18. Nama
: Amirullah S.Sos
Hari/tanggal wawancara
: 18 April 2016
Tingkat pendidikan
: SMA Negeri 3 Makssar
Umur
: 43 tahun 


\section{Argumentasi}

"Kami guru dan staff menghimbau ketika upacara, apel pagi selalu mengontrol pelajar yang menggunakan, langsung menegur kalau melihat mereka menggunakan smartphonenya. Pasti kita bertanya apa dilihat, mendekati meraka dengan baik, langsung menegur. Jadi cara mengontrol itu bukan hanya guru BK, namu semua guru di sekolah mulai dri kepala sekolah smpai ke satpam dn penjaga kantin kalau ada pelajar yang dicuragai menggunakan smartphonenya dengan tidak benar kangsung laporkan. Jadi bisa cepat ditindak lanjuti, jadi harus saling bekerja sama untuk mencegah kejadian yang buruk. Tapi ada juga pelajar itu yang memang dari awal masuk tidak berubah, terkadag ditegus satu dua kali tidak jerah, jadi kami menyurati orangtuanya.

19. Nama

Hari/tanggal wawancara

Tingkat pendidikan

Umur
: Drs. Amir

: senin, 18 April 2016

: SMA Negeri 3 Makssar

: 50 tahun

\section{Argumentasi}

“Di sekolah ini pelajar-pelajarnya itu menengah kebawah, ada juga anak pejabatan tapi tidak terlalu banyak, berapa dari non islam juga, memang kalau diliat pelajar sekarang itu ada beberapa yang kalangan kebawah kelihatan hobby nya itu tinggi, selerah mereka tinggi, pakai smartphone yang mahal, tapi tidak terlalu pintar juga dikelas, sering mengnggu temannya yang 
sedang belajar, pindah-pindah tempat duduk kita juga gurunya terjadang bingung memberikan nilai. Pakai terus itu smartphone nya, apa lagi kalau jam istirahat bisa itu di dalam saja itu diruangannya smpai jam masuk tidak keluar-keluar, itu mi mungkin pengaruhnya semuai itu tapi bagus juga itu kalau ada smartphone karena membantu pelajar yang lain dalam belajar.

20. Nama

Hari/tanggal wawancara

Tingkat pendidikan

Umur
: Dra. ariani

: selasa 18 April 2016

: SMA Negeri 3 Makssar

: 52 tahun

\section{Argumentasi}

"Di sekolah ini termasuk salah satu sekolah percontohan di kota makassar, dan memnag sesuai dengan visi kita disekolah ini kan mampu mengenal dunia teknologi dan pengembangan pengetahuan, jadi pelajar pun berhak untuk mengetahui itu semua melalui lah smartphone mereka. Kami disni membuka kelas khusus unggulan, jadi semua pelajar setiap kelas itu dilihat dinilai dan dipertimbangkan untuk layak masuk dikelas khusus, kelas khusus ini dilaksanakan diluar jam pelajaran sekolah, jadi bagi yang berprestasi di kelasnya masing-masing bisa lebih berprestasi lagi mengasah mengetahuannya didalam kelas tersebut, guru-guru pun sangat tekut mengajarnya. Jadi pelajar di sekolah ini semakin lama akan semkin banyak 
termotivasi untuk lebih belajar lagi, dan tidak melakukan hal-hal negatif dengan penggunaan smartphone. 
Lampiran 6. Daftar Informan

\begin{tabular}{|c|l|c|c|c|}
\hline No & \multicolumn{1}{|c|}{ Nama } & Jenis kelamin & Umur & Pekerjaan \\
\hline 1 & Amlyana & Perempuan & 16 tahun & Pelajar \\
\hline 2 & Ichsan rifky ramadhan & Laki-laki & 16 tahun & Pelajar \\
\hline 3 & Anisya namira syahrial & Perempuan & 17 tahun & Pelajar \\
\hline 4 & A.Muh. Danu tirta & Laki-laki & 15 tahun & Pelajat \\
\hline 5 & Hisbull djabbar & Laki-laki & 15 tahun & Pelajatr \\
\hline 6 & Jumniarti & Perempuan & 16 tahun & Pelajar \\
\hline 7 & Kevin jeremi & Laki-laki & 17 tahun & Pelajar \\
\hline 8 & Muh.Arif & Laki-laki & 15 tahun & Pelajar \\
\hline 9 & Muh. Fikri djami & Laki-laki & 15 tahun & Pelajar \\
\hline 10 & Dita maharani & perempuan & 17 tahun & Pelajar \\
\hline 11 & Muh. Aqil zulkarnaen & Laki-laki & 16 tahun & Pelajar \\
\hline 12 & Nur astriani & perempuan & 17 tahun & Pelajar \\
\hline 13 & Muh. Riadi arief & Laki-laki & 17 tahun & Pelajar \\
\hline 14 & Nadya khaerunnisa & perempuan & 17 tahun & Pelajar \\
\hline 15 & Nur ainun & perempuan & 16 tahun & Pelajar \\
\hline 16 & Saskia nur fiwisya & perempuan & 17 tahun & Pelajar \\
\hline 17 & Muh. Raja pratama & Laki-laki & 17 tahun & Pelajar \\
\hline 18 & Naufal akbar & Laki-laki & 16 tahun & Pelajar \\
\hline 19 & Dea muhammad fadil & Laki-laki & 16 tahun & Pelajar \\
\hline 20 & Muh. Rifky imam & Laki-laki & 16 tahun & Pelajar \\
\hline
\end{tabular}


Lampiran 7. Perbedaan Handphone dan Smartphone

\begin{tabular}{|l|l|l|l|}
\hline no & \multicolumn{1}{|c|}{ Handphone } & no & \multicolumn{1}{|c|}{ Smartphone } \\
\hline 1. & Tidak memiliki operating & 1. & Memiliki operating system (OS) \\
\hline system (OS) & $\begin{array}{l}\text { Software (perangkat lunak) } \\
\text { penyimpanan }\end{array}$ & 2. & Software (perangkat lunak) atau \\
data/dokumen terbatas & Kecepatan akses internet & 3. & Memiliki akses internet yang cepat \\
\hline 3. & terbatas & & \\
\hline 4. & Tombol bukan model & 4. & Tombol model QWERTY diadaptasi dari \\
& QWERTY & keybord komputer. \\
\hline 5. & Tidak dapat mengakses e- & 5. & Dapat mengakses e-mail dan memiliki \\
mail & & notifikasi. \\
\hline
\end{tabular}


Lampiran 8. Jadwal Kegiatan Penelitian

\begin{tabular}{|c|c|c|c|c|c|c|c|c|}
\hline \multirow{2}{*}{ No } & \multirow{2}{*}{ Kegiatan Peneliti } & \multicolumn{6}{|c|}{ Bulan ke } & \multirow{2}{*}{ Ket } \\
\hline & & 1 & 2 & 3 & 4 & 5 & 6 & \\
\hline \multirow{5}{*}{1} & Persiapan & & & & & & & \\
\hline & - Penyusunan proposal & $\sqrt{ }$ & $\sqrt{ }$ & & & & & \\
\hline & $\begin{array}{l}\text { - Pelaksanaan seminar } \\
\text { proposal }\end{array}$ & & & $\sqrt{ }$ & & & & \\
\hline & - Perbaikan/revisi proposal & & & $\sqrt{ }$ & & & & \\
\hline & - Pengurusan izin penelitian & & & $\sqrt{ }$ & & & & \\
\hline 2 & Pengumpulan data & & & & $\sqrt{ }$ & $\sqrt{ }$ & & \\
\hline 3 & Pengolahan dan analisis data & & & & & $\sqrt{ }$ & & \\
\hline 4 & $\begin{array}{l}\text { Penyusunan laporan } \\
\text { penelitian }\end{array}$ & & & & & $\sqrt{ }$ & & \\
\hline 5 & Pelaksanaan seminar hasil & & & & & & $\sqrt{ }$ & \\
\hline 6 & Perbaikan laporan penelitian & & & & & & $\sqrt{ }$ & \\
\hline 7 & Penyajian laporan/ujian tesis & & & & & & $\sqrt{ }$ & \\
\hline
\end{tabular}


Lampiran 9. Jenis /merek smartphone yang digunakan

\begin{tabular}{|c|l|c|c|}
\hline No & \multicolumn{1}{|c|}{ Nama } & Jenis samrtphone & Aktif menggunakan \\
\hline 1 & Amlyana & Samsung & 3 tahun \\
\hline 2 & Ichsan rifky ramadhan & Iphone 4 & 3 tahun \\
\hline 3 & Anisya namira syahrial & Iphone 5 & 2 tahun \\
\hline 4 & A.Muh. Danu tirta & Oppo & 2 tahun \\
\hline 5 & Hisbull djabbar & Asus & 1 tahun \\
\hline 6 & Jumniarti & Samsung & 1 tahun \\
\hline 7 & Kevin jeremi & Samsung & 3 tahun \\
\hline 8 & Muh.Arif & Oppo & 3 tahun \\
\hline 9 & Muh. Fikri djami & Blackberry & 4 tahun \\
\hline 10 & Dita maharani & Backberry & 4 tahun \\
\hline 11 & Muh. Aqil zulkarnaen & Samsung & 1 tahun \\
\hline 12 & Nur astriani & Oppo & 2 tahun \\
\hline 13 & Muh. Riadi arief & Oppo & 2 tahun \\
\hline 14 & Nadya khaerunnisa & Blackberry & 3 tahun \\
\hline 15 & Nur ainun & Samsung & 3 tahun \\
\hline 16 & Saskia nur fiwisya & Samsung & 3 tahun \\
\hline 17 & Muh. Raja pratama & Asus & 2 tahun \\
\hline 18 & Naufal akbar & Sony & 2 tahun \\
\hline 19 & Dea muhammad fadil & Iphone 5 & 4 tahun \\
\hline 20 & Muh. Rifky imam & Sony & 3 tahun \\
\hline & & & \\
\hline & & & \\
\hline
\end{tabular}




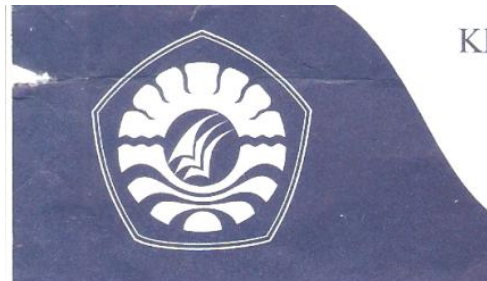

\section{KEMENTERIAN RISET, TEKNOLOGI, DAN PENDIDIKAN TINGGI UNIVERSITAS NEGERI MAKASSAR \\ FROGRAM PASCASARJANA}

Kampus UNM Gı nungsari Baru, Jl. Bonto Langkasa, Makassar-90222,

Telp. 0411) 830366, Telp./Fax. (0411) 855288,

Email: pasca@unm.ac.id, Laman: http://pps.unm.ac.id

\section{SURAT KETERANGAN PERBAIKAN UJIAN TESIS}

Berdasarkan Ujian Tesis untuk Penyusunan Tesis

$\begin{array}{ll}\text { N a m a } & \text { : Nur Inayati Saiful } \\ \text { Nomor Pokok } & : \text { 14B02017 } \\ \text { Program Studi } & : \text { Pend.IPS } \\ \text { Kekhususan } & : \text { IPS / Sosiologi } \\ \text { Judul Tesis } & :\end{array}$

Teknologi dan Perilaku Sosial Pelajar (Studi Tentang Dampak Penggunaan Smartphone di SMA Negeri 3 Makassar)

Oleh Tim Penilai, harus dilakukan perbaikan-perbaikan. Perbaikan tersebut dilakukan dan telah disetujui oleh Tim Penilai .

\begin{tabular}{|c|l|c|}
\hline No. & \multicolumn{1}{|c|}{ Nama Tim Penilai } & $\begin{array}{c}\text { Disetujui } \\
\text { Tanggal }\end{array}$ \\
\hline 2 & Prof. H. Hamdan Juhannis, MA., Ph.D. & Dr. Firdaus W. Suhaeb, M.Si.
\end{tabular}




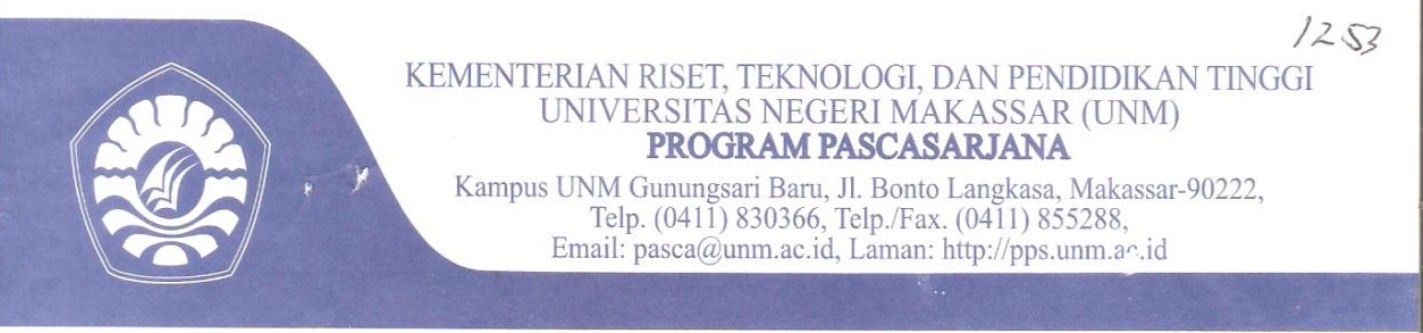

SURAT KETERANGAN PERBAIKAN SEMINAR

Berdasarkan Seminar Usul Penelitian untuk Penyusunan Tesis

$\mathrm{N}$ a m a : Nur Inayati Saiful

Nomor Pokok : :14B02017

Program Studi : IPS

Kekhususan : Pendidikan Sosiologi

Judul Tesis

“Teknologi dan Perilaku Sosial Pelajar (Studi Tentang Dampak Penggunaan Smartphone di SMA Negeri 3 Makassar"

Oleh Tim Penilai, harus dilakukan perbaikan - perbaikan. Perbaikan tersebut dilakukan dan telah disetujui oleh Tim Penilai.

\begin{tabular}{|c|l|c|}
\hline No. & \multicolumn{1}{|c|}{ Nama Tim Penilai } & $\begin{array}{c}\text { Disetujui } \\
\text { Tanggal }\end{array}$ \\
\hline 1 & Prof. H. Hamdan Juhannis, M.A.,Ph.D. & Tanda Tangan \\
\hline 2 & Dr. Firdaus W. Suhaeb, M.Si. & $2 / 1-1-2016$ \\
\hline 3 & Dr. Hj. Syamsidah, M.Pd. & $2 / 1-2016$
\end{tabular}

Makassar,

2016

Mengetahui :

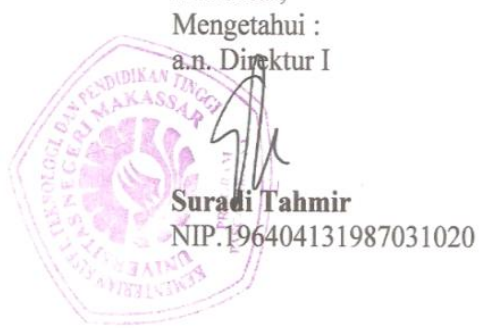

Tetap Jaya dalam Tantangan 


\section{SURAT KETERANGAN PERBAIKAN UJIAN TESIS}

Berdasarkan Ujian Tesis untuk Penyusunan Tesis

$\begin{array}{ll}\text { N a m a } & : \text { Nur Inayati Saiful } \\ \text { Nomor Pokok } & : \text { 14B02017 } \\ \text { Program Studi } & : \text { Pend.IPS } \\ \text { Kekhususan } & : \text { IPS / Sosiologi } \\ \text { Judul Tesis } & :\end{array}$

Teknologi dan Perilaku Sosial Pelajar

(Studi Tentang Dampak Penggunaan Smartphone di SMA Negeri 3 Makassar)

Oleh Tim Penilai, harus dilakukan perbaikan-perbaikan. Perbaikan tersebut dilakukan dan telah disetujui oleh Tim Penilai .

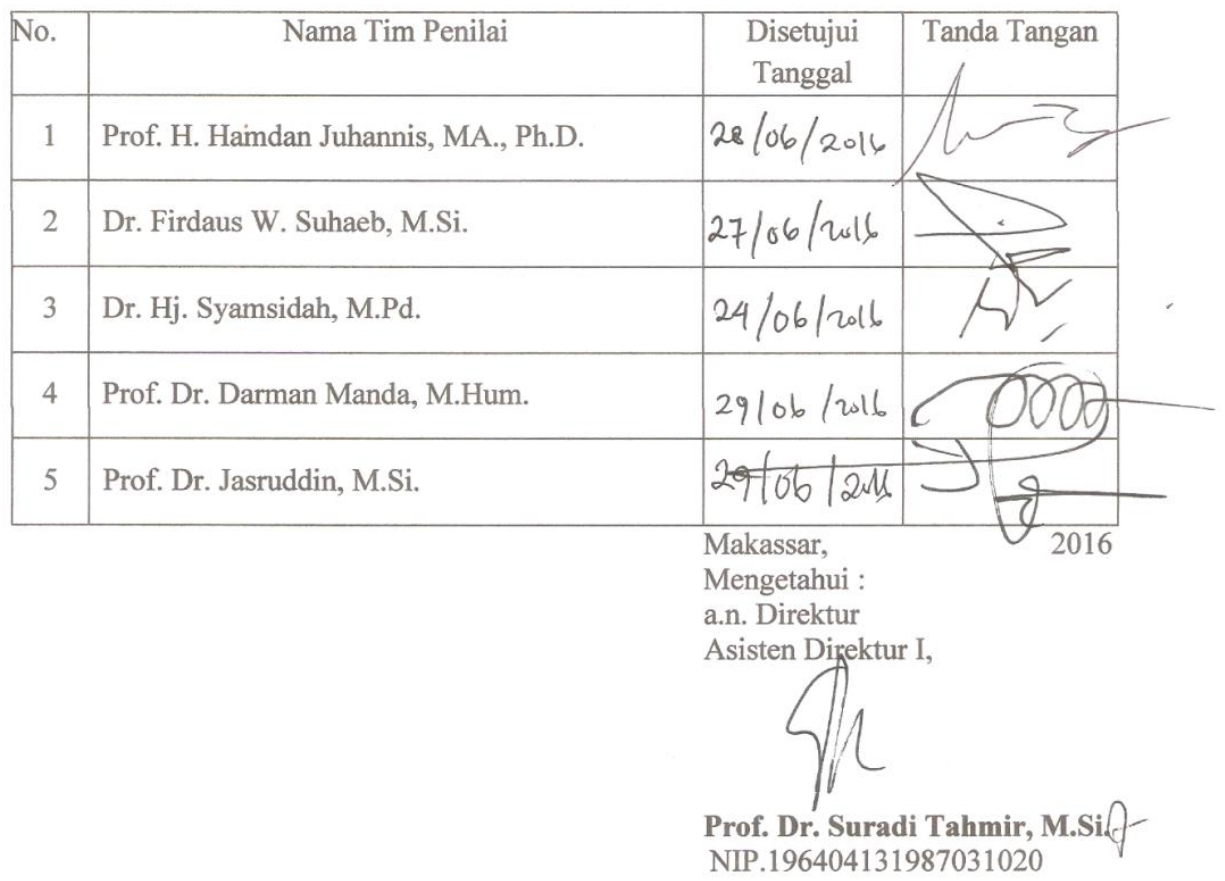

Tetap Jaya dalam Tantangan 


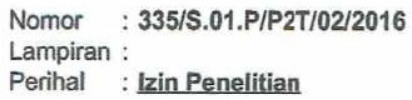

KepadaYth.

Walikota Makassar

di-

Tempat

Berdasarkan surat Direktur PPs UNM Makassar Nomor : 1253/UN36.8/KM/2016 tanggal 03 Februari 2016 perihal tersebut diatas, mahasiswa/peneliti dibawah ini:

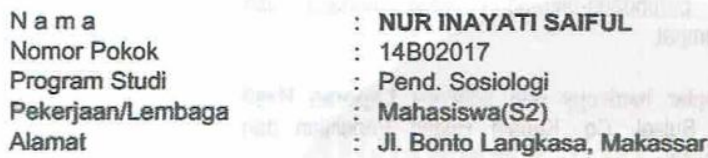

Bermaksud untuk melakukan penelitian di daerah/kantor saudara dalam rangka penyusunan Tesis, dengan judul

" TEKNOLOGI DAN PERILAKU SOSIAL PELAJAR (STUDI TENTANG DAMPAK PENGGUNAAN SMARTPHONE DI SMA NEGERI 3 MAKASSAR) "

Yang akan dilaksanakan dari : Tgl. 09 Februari s/d 30 April 2016

Sehubungan dengan hal tersebut diatas, pada prinsipnya kami menyetujui kegiatan dimaksud dengan ketentuan yang tertera di belakang surat izin penelitian.

Demikian Surat Keterangan ini diberikan agar dipergunakan sebagaimana mestinya.

Diterbitkan di Makassar

Pada tanggal : 05 Februari 2016

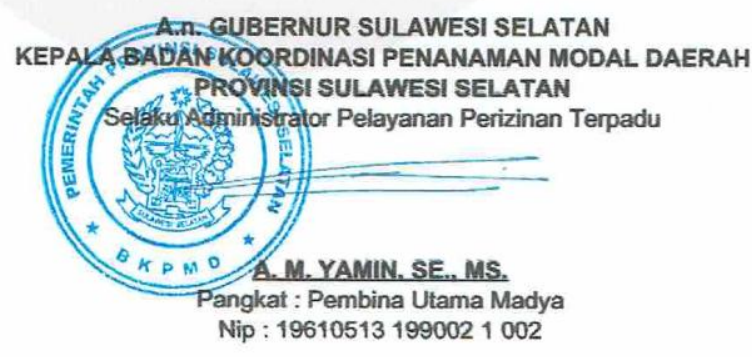

Tembusan Yth

1. Direktur PPs UNM Makassar,

2. Pertinggal. 


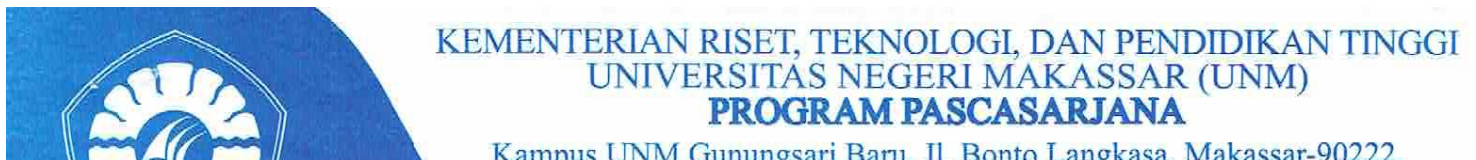

Kampus UNM Gunungsari Baru, Jl. Bonto Langkasa, Makassar-90222, Telp. (0411) 830366, Telp./Fax. (0411) 855288,

Email:pasca@unm.ac.id, Laman: http://pps.unm.ac.id

$$
\begin{array}{ll}
\text { Nomor } & : 1253 / \mathrm{UN} 36.8 / \mathrm{KM} / 2016 \\
\text { Lamp. } & : 1 \text { (satu) Proposal } \\
\text { Perihal } & \text { : Izin Penelitian }
\end{array}
$$

Yth Gubernur Provinsi Sulawesi Selatan Cq. Badan Koordinasi Penanaman Modal Daerah

\section{Makassar}

Dengan hormat disampaikan bahwa, mahasiswa Program Pascasarjana Universitas Negeri Makassar yang tersebut di bawah ini akan melaksanakan penelitian dalam rangka penyelesaian studi magister.

$$
\begin{array}{ll}
\text { Nama } & \text { : Nur Inayati Saiful } \\
\text { Nim } & \text { : 14B02017 } \\
\text { Program Studi } & \text { : IPS. } \\
\text { Kekhususan } & \text { : Pendidikan Sosiologi } \\
\begin{array}{l}
\text { Judul Penelitian } \\
\text { "Teknologi dan Perilaku Sosial Pelajar (Studi Tentang Dampak Penggunaan } \\
\text { Smartphone di SMA Negeri } 3 \text { Makassar" }
\end{array}
\end{array}
$$

Sehubungan dengan hal tersebut di atas, dimohon kiranya yang bersangkutan dapat diberikan izin Penelitian

Atas perhatian dan kerjasama yang baik diucapkan Terima kasih.

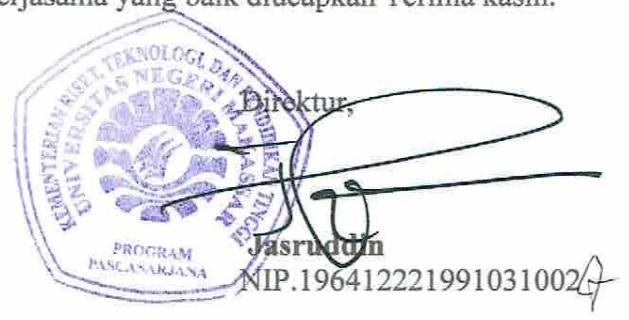

Tembusan :

- Rektor UNM (sebagai laporan)

- Asdir II PPs UNM

- KPS IPS.

- Mahasiswa yang bersangkutan 


\title{
PEMERINTAH KOTA MAKASSAR DINAS PENDIDIKAN DAN KEBUDAYAAN
}

Jl. Lețen Hertasning No. 8 Telp. (0411) 868073 Faks. 869256 Makassar 90222

Website:hitp/www.dikbud-makassar.info ; e-mail:dikbud.makassar@yahoo.com

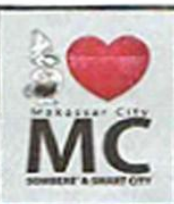

IZIN PENELITIAN

NOMOR :070/0154/DPK/IL/2016

Dasar

: Surat Kepala Kantor Badan Kesatuan Bangsa Kota Makassar Nomor : 070/390-IL/BKBP/IL/2016 Tanggal 10 Februari 2016

Maka Kepala Dinas Pendidikan Dan Kebudayaan Kota

Makassar

Kepada

\section{MENGIZINKA N}

$\begin{array}{ll}\text { Nama } & \text { : Nur Inayati Saiful } \\ \text { NIM / Jurusan } & : 14 \mathrm{~B} 02017 / \text { Pend.Sosiologi } \\ \text { Pekerjaan } & : \text { Mahasiswa (S2) } \\ \text { Alamat } & : \text { JL.Bonto Langkasa, Makassar }\end{array}$

Untuk

\begin{abstract}
: Mengadakan Penelitian Di SMA Negeri 3 Makassar Dalam Rangka Penyusunan Tesis di PPs UNM Makassar di Makassar dengan judul penelitian :

"TEKNOLOGI DAN PERILAKU SOSLAL PELAJAR (STUDI TENTANG DAMPAK PENGGUNAAN SMARTPHONE DI SMA NEGERI 3 MAKASSAR)"
\end{abstract}

Dengan Ketentuan sebagai berikut :

Harus melapor pada Kepala Sekolah yang bersangkutan

1. Tidak mengganggu proses kegiatan belajar mengajar di Sekolah

2. Harus mematuhi tata tertib dan peraturan di Sekolah yang berlaku

3. Hasil penelitian 1 ( satu ) examplar di laporkan kepada Kepala Dinas Pendidikan Kota Makassar

Demikian izin penelitian ini di berikan untuk di gunakan sebagaimana mestinya

Dikeluarkan di : Makassar

Pada Tanggal : 11 Februari 2016

An. Kepala Dinas Pendidikan Dan

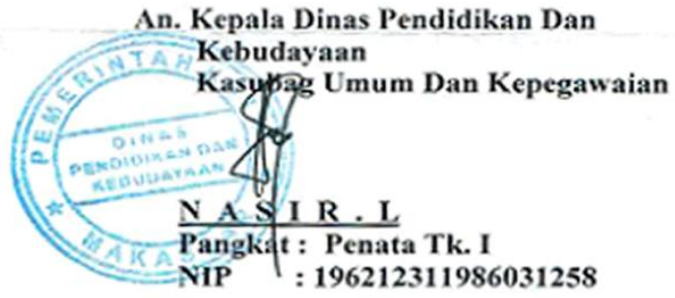




\section{Lampiran 10. Dokumentasi}

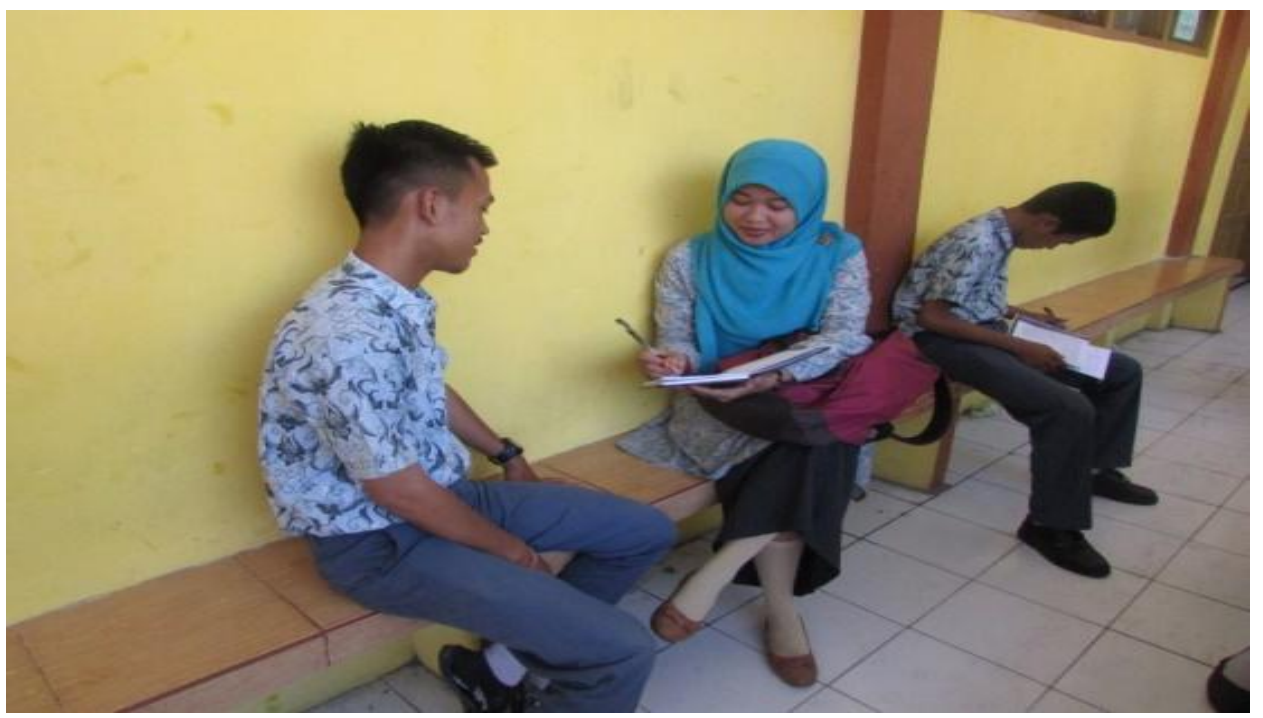

(wawancara bersama pelajar di depan kelasnya saat jam istirahat berlangsung, februari 2016)

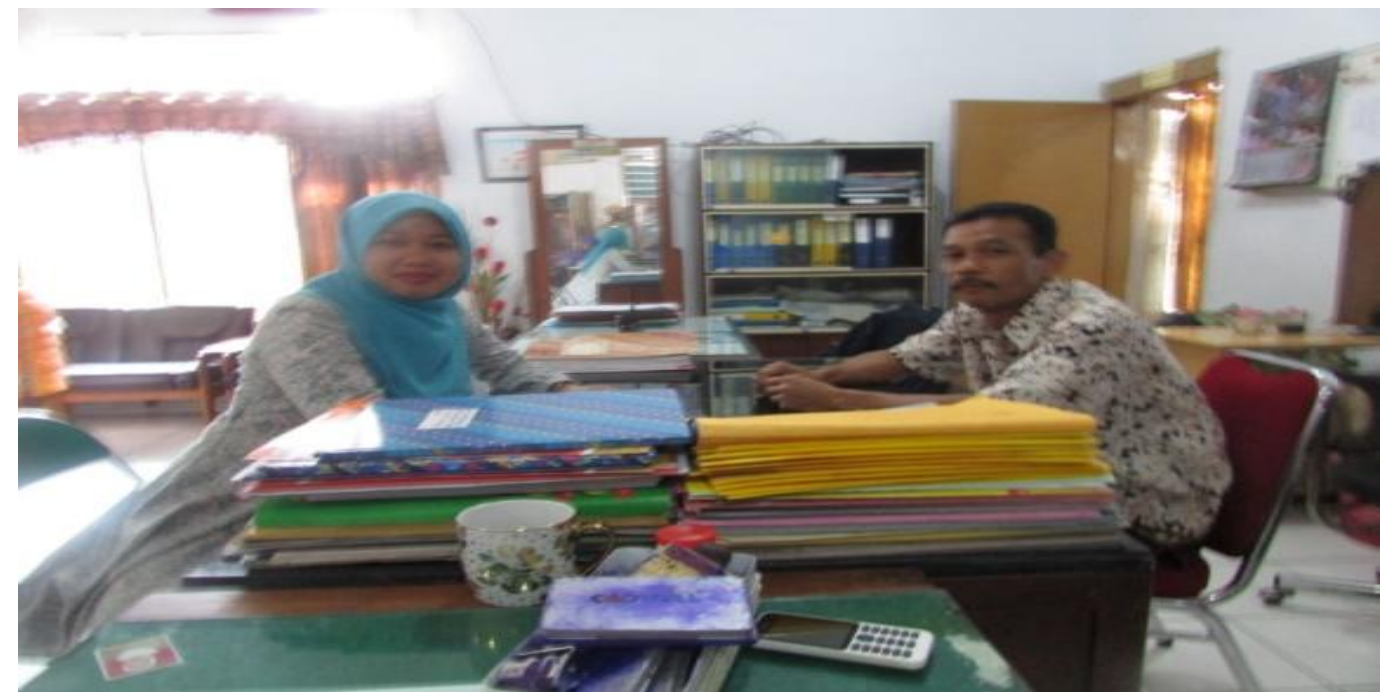

(wawancara bersama salah satu pegawai Tata Usaha, atas nama Muh. Saleh, sos.) 


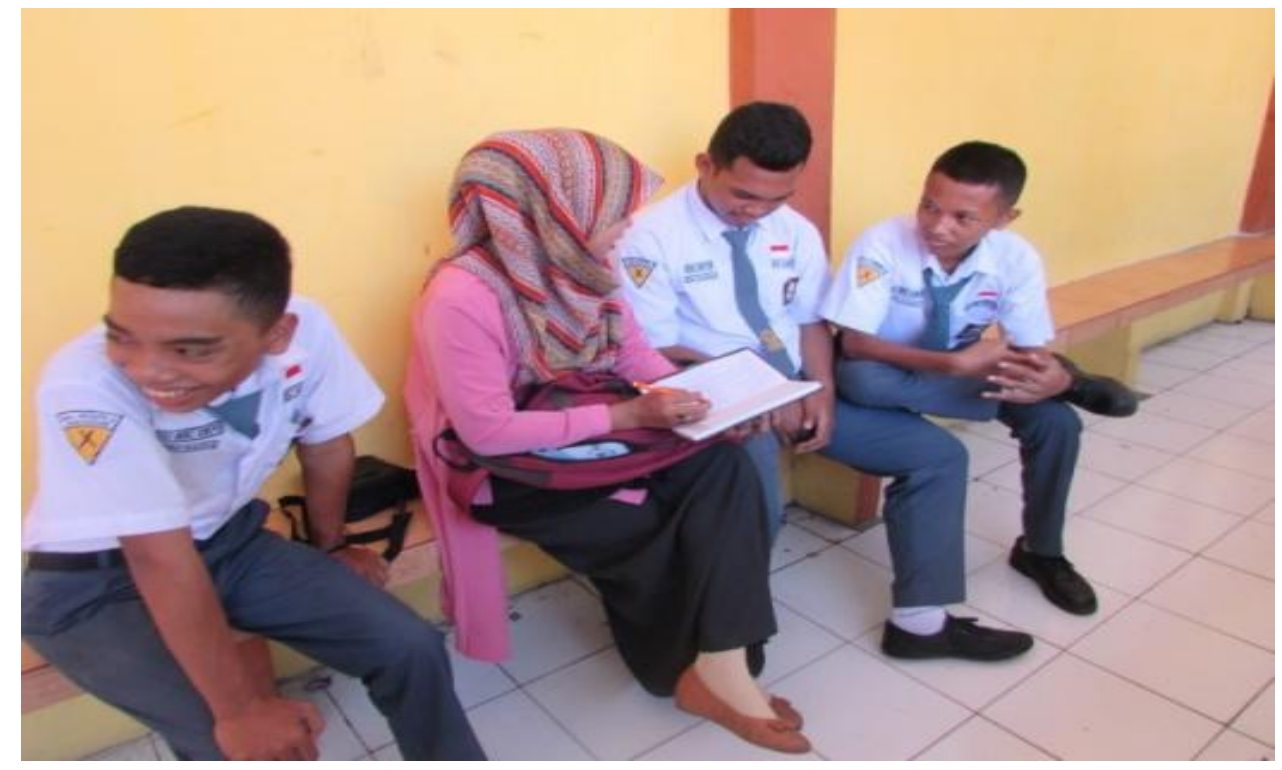

(wawancara bersama beberapa pelajar di depan kelasnya, maret 2016)

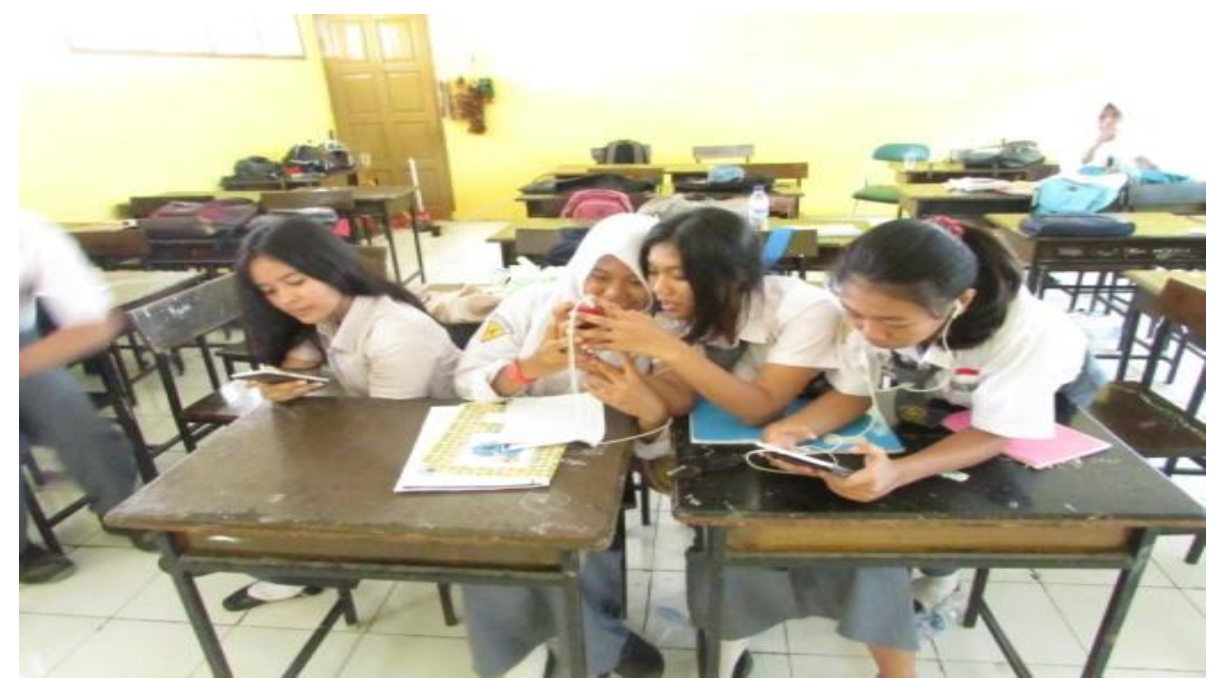

(mengamati, beberapa pelajar yang menggunakan smartphonenya, maret 2016) 


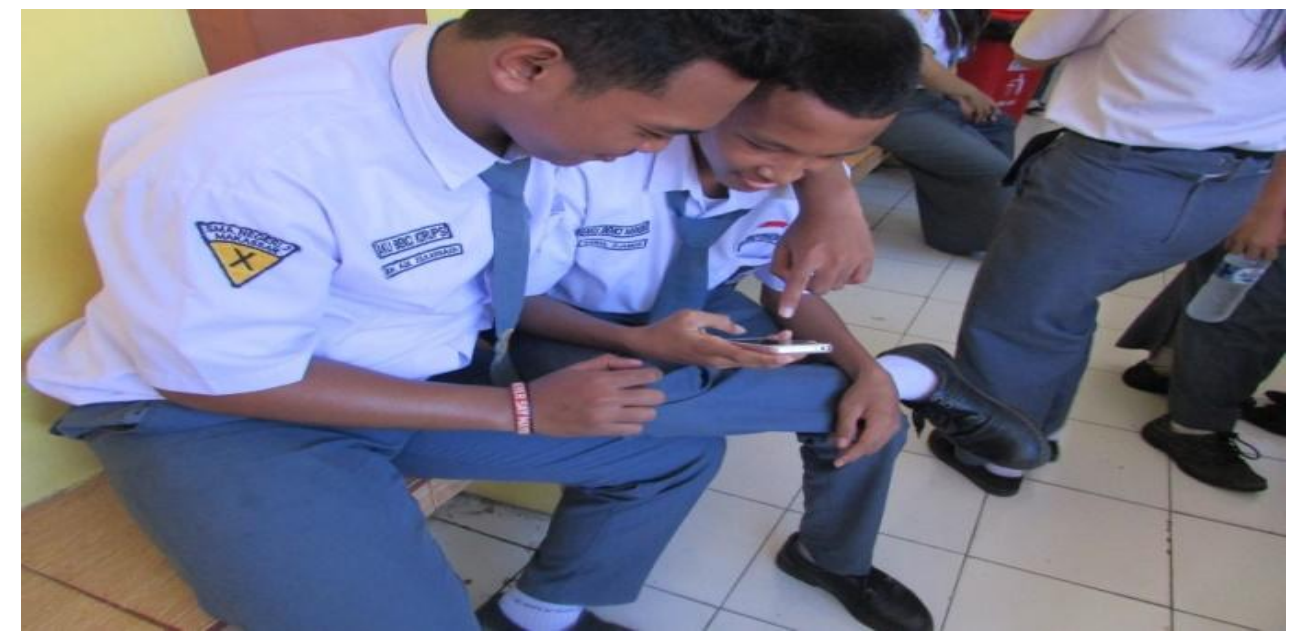

(mengamati pelajar dalam penggunaan smartphonenya, Maret 2016)

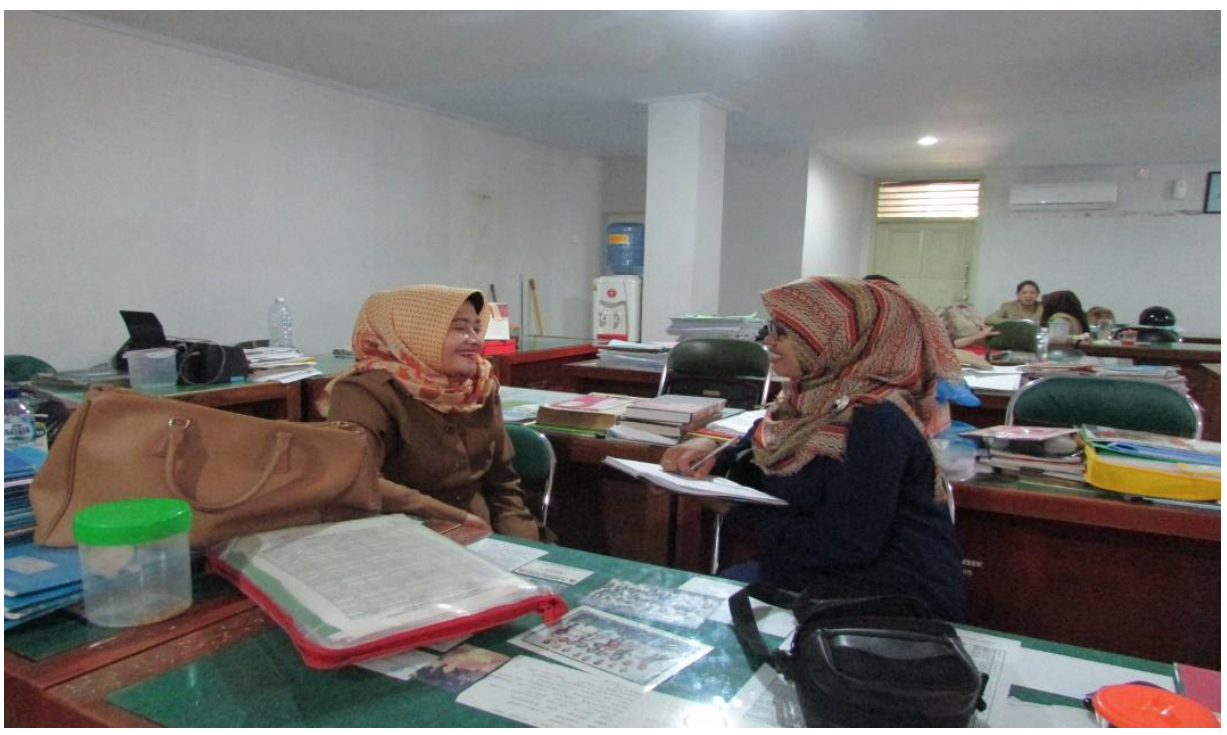

(Wawancara bersama salah satu wali kelas, atas nama Dra. Ariani) 


\section{Lampiran 11. Peta SMA Negeri 3 Makassar}

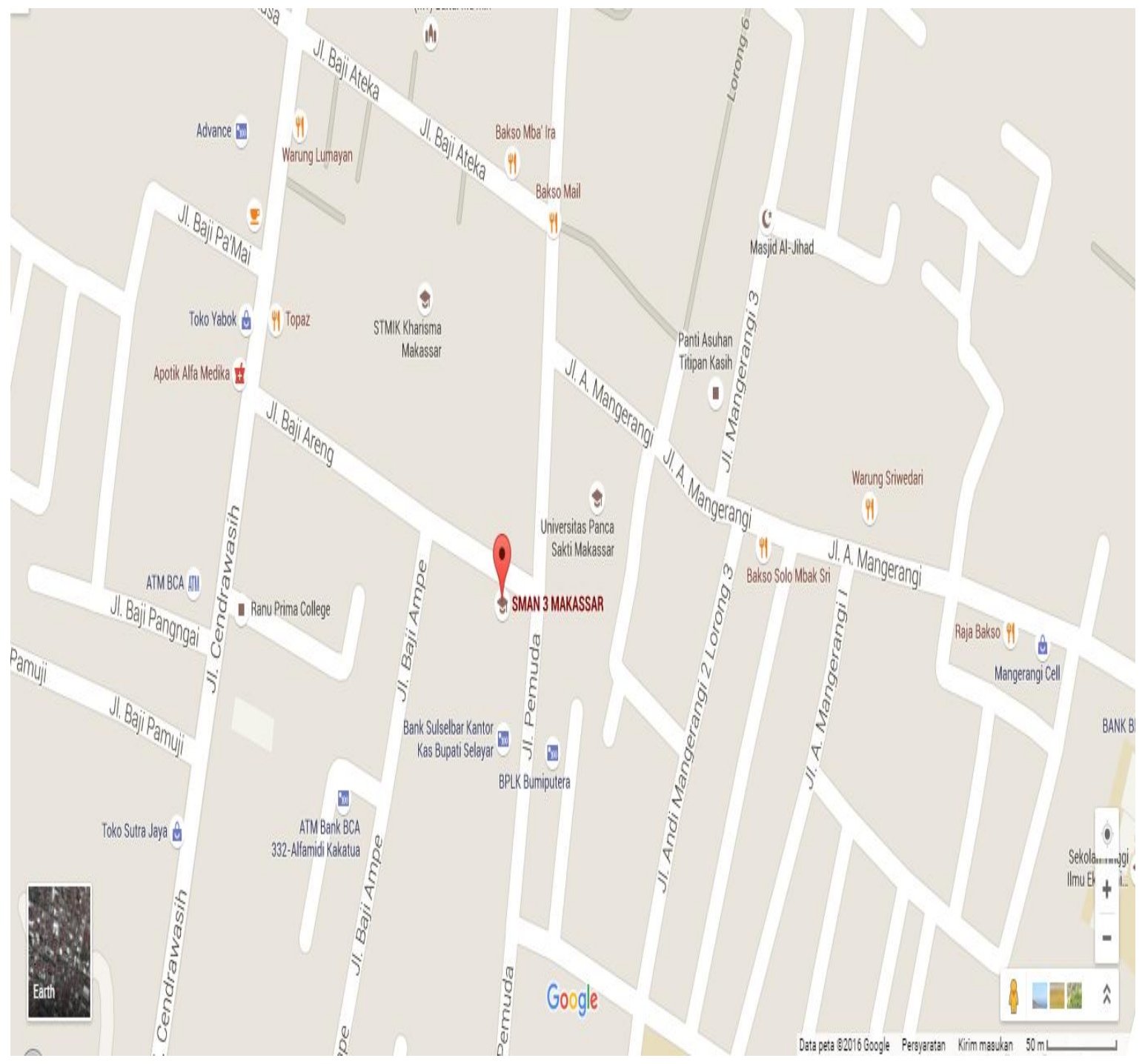


